Claremont Colleges

Scholarship@ Claremont

2012

\title{
The Interaction of Political Capacity and Economic Growth to Attract Foreign Direct Investments at the Provincial Levels of Developing Countries
}

Murniz Allen Vasay Coson

Claremont Graduate University

\section{Recommended Citation}

Coson, Murniz Allen Vasay, "The Interaction of Political Capacity and Economic Growth to Attract Foreign Direct Investments at the Provincial Levels of Developing Countries" (2012). CGU Theses \& Dissertations. Paper 16.

http://scholarship.claremont.edu/cgu_etd/16

DOI: $10.5642 /$ cguetd $/ 16$

This Open Access Dissertation is brought to you for free and open access by the CGU Student Scholarship at Scholarship @ Claremont. It has been accepted for inclusion in CGU Theses \& Dissertations by an authorized administrator of Scholarship @ Claremont. For more information, please contact scholarship@cuc.claremont.edu. 


\title{
The Interaction of Political Capacity and Economic Growth to Attract Foreign Direct Investments at the Provincial Levels of Developing Countries
}

\section{BY}

\section{Murniz Allen Vasay Coson}

\begin{abstract}
A Dissertation submitted to the Faculty of the Claremont Graduate University in partial fulfillment of the requirements for the degree of Doctor of Philosophy in Economics and Political Science.
\end{abstract}

Claremont, California

2012

Approved by:

Dr. Jacek Kugler, Chair 
(C) Copyright by Murniz Allen Vasay Coson 2012

All Rights Reserved 
We, the undersigned, certify that we have read this dissertation and approve it as adequate in scope and quality for the degree of Doctor of Philosophy.

Dissertation Committee:

Jacek Kugler, Ph.D., Chair

Yi Feng, Ph.D., Member

Mark Abdollahian, Ph.D., Member 


\title{
The Interaction of Political Capacity and Economic Growth to Attract Foreign Direct Investments at the Provincial Levels in Developing Countries
}

\author{
Murniz Allen Vasay Coson \\ Claremont Graduate University \\ 2012
}

\begin{abstract}
This dissertation will explore how developing provinces within countries attract foreign direct investment. The policy implication to this study is important because it could account for the uneven distribution of growth in developing countries that so frequently leads to dual economies. To attract foreign direct investments, provincial governments compete among themselves trying to appeal to international investors.
\end{abstract}

There is consensus in the economic development literature that both economic and political variables interact to advance a nation's economy. The ability for a country to provide a free market economy to exchange goods and ideas makes the environment more favorable for investors, hence it makes sense to focus on institutions that can attract FDI if the government is committed to developing its economy and compete in the global market. Political factors serves as an important component of strengthening a country's economy. Political variables such as political capacity have helped ensure the success of a growing economy. Governments must possess the ability to extract resources from its people, thereby pursuing policy goals to create a more favorable market environment for investors. Investors then feel more confident and comfortable investing in these economies. This political variable has 
helped countries redefine themselves in the global community as credible and safe countries for investment. However, this political variable alone is not enough to explain how to attract foreign direct investments in developing countries. Rather, governments must also possess the economic tools necessary, such as economic growth and an open economy. These economic tools combined with political capacity can effectively attract foreign direct investments. Many provinces in developing countries lack these variables, thereby jeopardizing the opportunity to attract foreign direct investments and compete in the global market. Hence, I look at both the political and economical variables as an interaction variable as a strong indicator to attract foreign direct investments.

If my work is successful, I hope that these findings can serve as a policy tool for provinces of developing countries to effectively attract foreign direct investments in a competitive global market. 
Dedicated to my family 


\section{ACKNOWLEDGEMENTS}

To my parents, Ramon and Floramar, who are responsible for financing both my undergraduate and graduate education, which allowed me to pursue a $\mathrm{PhD}$. Thank you for all of your support! Also, to my younger brother, Adrian, who has assisted me in babysitting my sons for so many months, and believed in me that I can finish even with a family. I will always be proud of you bro!

And especially to my lovely wife, Cheryl, who has supported me throughout my educational tenure, and will continue to be my motivation for my educational goals and aspirations. I love you very, very much! Lastly, to my wonderful sons, Brayden and Darren, who makes me smile every time I see them both reminding me of how special my life truly is; this achievement is dedicated to the both of you! 


\section{CONTENTS}

ACKNOWLEDGEMENTS .................................... vii

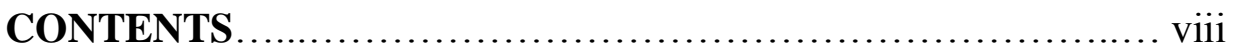

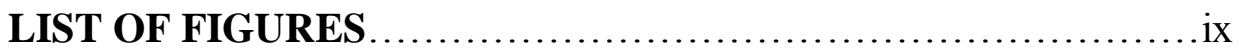

CHAPTER 1: INTRODUCTION AND RESEARCH QUERY.......... 1

CHAPTER 2: LITERATURE REVIEW........................... 15

CHAPTER 3: METHODS ..................................... 31

CHAPTER 4: RESULTS................................... 39

CHAPTER 5: CONCLUSION ................................ 87

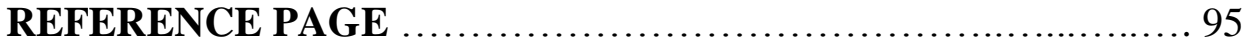

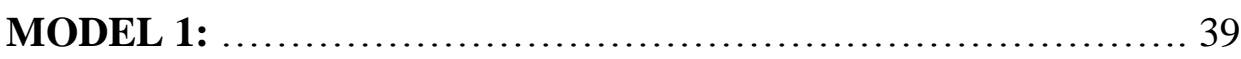

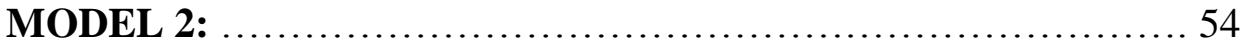

MODEL 3: ................................................... 65

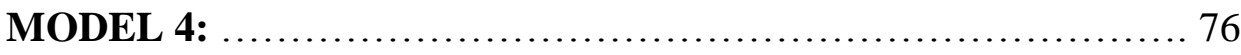

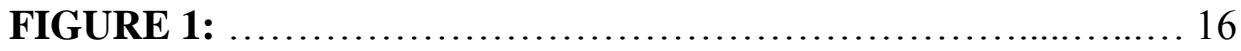

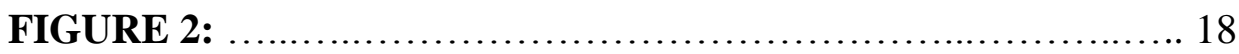

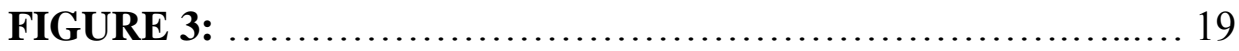

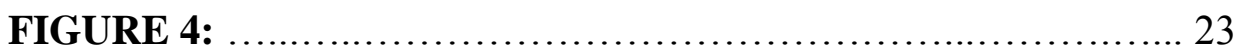

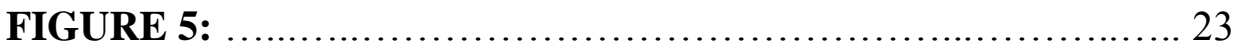

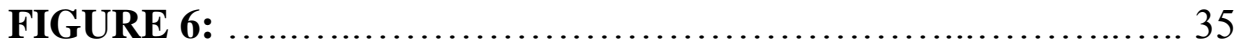

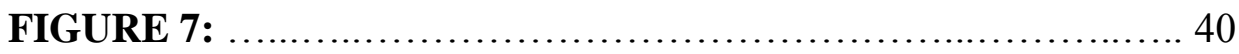

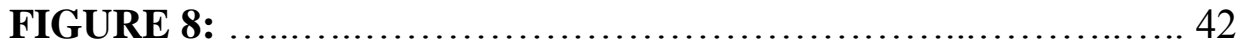




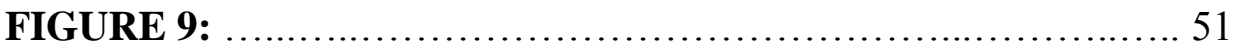

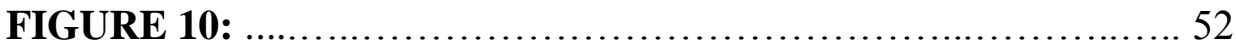

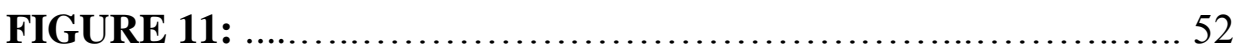

FIGURE 12: ................................................... 53

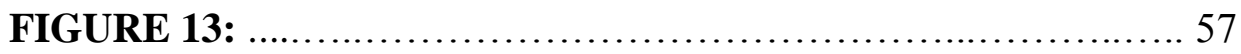

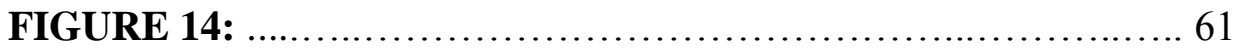

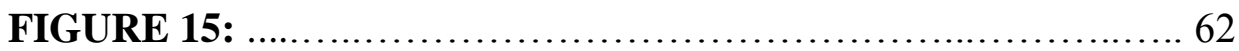

FIGURE 16: ................................................. 62

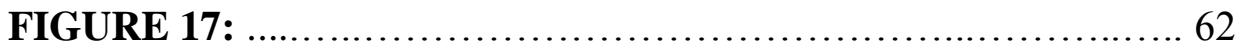

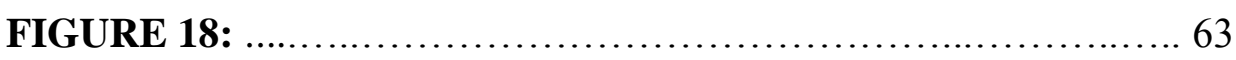

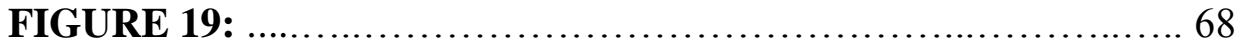

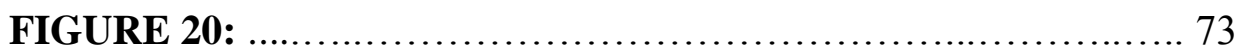

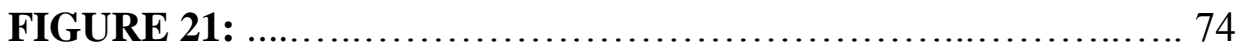

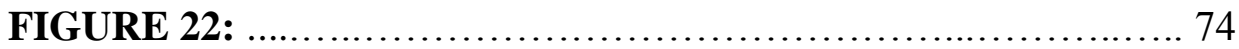

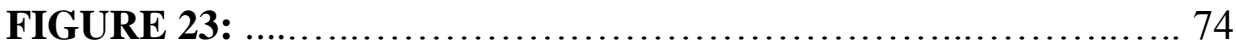

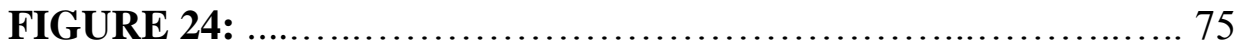

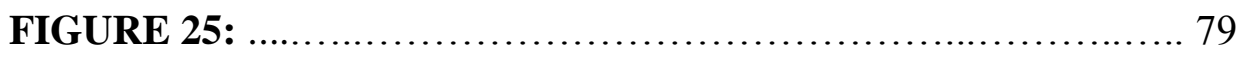

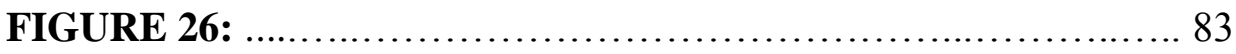

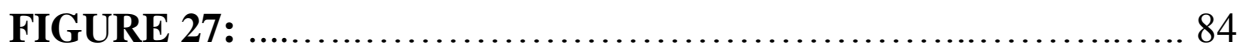

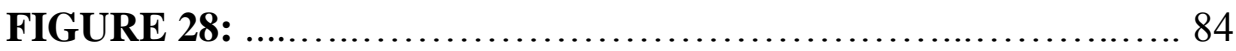

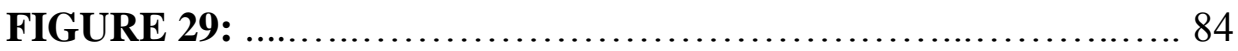

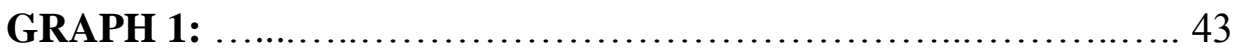

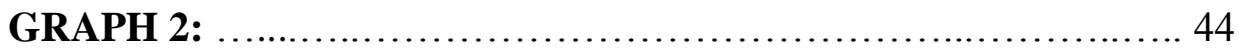


GRAPH 3: 45

GRAPH 4: 45

GRAPH 5: 46

GRAPH 6: 47

GRAPH 7: 48

GRAPH 8: 49

GRAPH 9: 50

GRAPH 10: 51

GRAPH 11: 57

GRAPH 12: 58

GRAPH 13: 59

GRAPH 14: 60

GRAPH 15: 61

GRAPH 16: 64

GRAPH 17: 69

GRAPH 18: 70

GRAPH 19: 71

GRAPH 20: 72

GRAPH 21: 73

GRAPH 22: 79

GRAPH 23: 80

GRAPH 24: 81 GRAPH 25: 82 
GRAPH 26: 83

APPENDIX A: 99

APPENDIX B: 100

APPENDIX C: 101

APPENDIX D: 102

APPENDIX E: 103

APPENDIX F: 104

APPENDIX G: 105

APPENDIX H: 106

APPENDIX I: 107

APPENDIX J: 108

APPENDIX K: 109

APPENDIX L: 110

APPENDIX M: 111

APPENDIX N: 112

APPENDIX O: 113

APPENDIX P: 114

APPENDIX Q: 115

APPENDIX R: 116

APPENDIX S: 117

APPENDIX T: 118

APPENDIX U: 119 APPENDIX V: 120 
APPENDIX W:

APPENDIX X:

APPENDIX Y:

APPENDIX Z: ........................................ 124

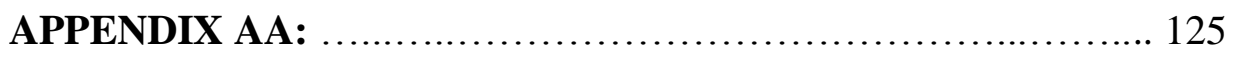




\section{The Interaction of Political Capacity and Economic Growth to Attract Foreign Direct Investments at the Provincial Levels in Developing Countries}

\section{CHAPTER 1 \\ INTRODUCTION AND RESEARCH QUERY}

In the twenty-first century, capitalism continues to flourish especially in developing countries found in Asia, Latin America, and Africa (World Bank 2005). Private investment is a key to capitalism. Investments comes in many forms, but domestic investment (DI) is primarily used to measure a country's ability to grow economically. However, a growing trend in the literature has focused on another type of investment called foreign direct investments (FDI). Such investments provide compelling data for development in countries where DI is limited and/or scarce. FDI is used to stimulate a country's economy with the intentions of becoming self-sufficient and to compete in the global market. Studies have shown that FDI and economic development are both positive and highly correlated (Borensztien 1998). Moreover, FDI has improved many countries' infrastructures and industries due to its cost effectiveness, by concurrently emulating or importing these technologies from developed countries (OECD 2002).

This dissertation will explore how provincial governments within developing countries can attract foreign direct investments. The policy implication to this study is important because it could account for the uneven distribution of growth at the provincial level in developing countries. To attract foreign direct investments, provincial governments must compete among themselves by appealing to international investors that 
it is committed in improving the growth of the nation through sets of political and economical policies.

There is consensus in the development literature that both economic and political variables interact to advance economic development (De Soto 2000). Economic variables, such as output from main industries: primary (mining), secondary (manufacturing), and tertiary (services) greatly contribute to a developing country's economy (World Bank 2004). The ability for a country to provide a free market economy to exchange goods and ideas makes the environment more favorable for investors (World Bank 2005). In addition to these variables, it makes sense to focus on the institutions that extract resources from its people, thereby implementing sound policies to attract FDI and compete in the global market. Political factors serves as an important component for strengthening a country's economy. Political variables such as political capacity have helped ensure the success of many developing countries through the ability of making a more favorable market environment for international investors, thus alleviating the sense of anxiety and fear from lost investments (World Bank 2004).

These political variables have helped countries redefine themselves in the global community as credible and safe countries for investments. However, these economic and political factors alone are not enough to explain how provincial governments in developing countries effectively attract foreign direct investments. Provincial governments must possess both the economic growth and the political capacity to effectively attract foreign direct investments. Many provinces within developing countries lack either the economic or political variable needed to convince international investors that it is safe to invest in its province, thereby hurting the opportunity to effectively attract foreign direct investments. Hence, we look at the interaction of 
political capacity and economic growth as a strong indicator to attract foreign direct investments.

\section{RESEARCH OBJECTIVES}

This paper will try to explain that political capacity alone in provincial governments is enough to effectively attract foreign direct investments, rather a combination of economic growth and political capacity are needed to make the environment favorable for international investors. Based on modifications of the work by Coan and Kugler (2009), we will investigate how provincial governments of three developing countries - China, India, and Indonesia - depend on this interaction variable to attract FDI. The model incorporates provincial data from 1994-2000 from the World Bank, International Monetary Fund (IMF), and the United Nations (UN).

If our work is successful, we hope that these findings can serve as a policy tool for provinces of developing countries to effectively attract foreign direct investments and compete in the global market.

\section{RESEARCH DESIGN}

To attract FDI, provincial governments in developing countries need to establish institutions and provide opportunities in industries through the adoption of economic policies committed in improving the nation's economy. We propose that the combination of both economic growth and political capacity will allow provincial governments to 
effectively attract foreign direct investments. Such arguments are summarized in the following hypothesis:

H1: The interaction of Political Capacity and Economic Growth leads to provincial governments in developing countries to effectively attract FDI

We can represent this argument in the following form:

$$
\begin{gathered}
F D I=b_{0}+b_{1}(R P C)_{i t}+b_{2}(G D P)_{i t}+b_{3}\left(R P C^{*} G D P\right)_{i t}+b_{4}(\text { Democracy })_{i t}+b_{5}(\text { Open } \\
\text { Economy })_{i t}+e_{i t}
\end{gathered}
$$

Where FDI represents the stock flow amount of foreign direct investments in a provincial government in a given year; RPC represents the measure of a province's relative political capacity; GDP represents the value of all final commodities and services produced in a province in a given year; RPC*GDP represents the interaction between the provincial government's relative political capacity and gross domestic product; Democracy represents India and Indonesia and is added as a dummy variable, while China represents 'Non-Democracy;' Open Economy represents the provinces' openness through an issue continuum from a scale of 0 (close economy) to 100 (open economy); and e represents the stochastic error term.

In order to understand the effects of FDI, there needs to be a fundamental explanation for the importance of economic growth, such as GDP in a developing nation. There is consistent trend in the field arguing for economic and political variables to exist for economic growth to commence (De Soto 2000). Economic variables such as economic growth rates, gross domestic product per capita (GDP per capita), and 
industrialization greatly contribute to a developing country's economy. Moreover, the ability for a country to provide economic freedom through enforcement of property rights and the ease of capital mobility increases the investors' comfort levels to invest in the country (World Bank 2004). It makes sense for countries to focus on its industries to attract FDI if they are committed in boosting its economy bettering the lives of its nation and its citizens.

In addition, political factors have also served as an important component of strengthening a country's economy. Political variables such as civil liberties and civil rights have helped ensure the success of a growing economy as investors are exposed to individual freedoms granted and protected by the government alleviating any concerns for political tyranny and political power abuse, which leads to corruptive measures (World Bank 2004). These political variables have helped countries redefine themselves in the global community as credible and safe countries for many things, especially to boost an ailing economy into a global competitor through attracting FDI. Plus, these political variables also reminds international investors similar political freedoms they enjoy back home reassuring them that it is a safe country for investments. However, these variables do not provide a complete explanation of what attracts FDI into a provincial government in a developing country. It is important to analyze the correlation between economic and political variables with a country's economic levels, but it is more vital to understand why international investors are willing to invest in a provincial government. Political institutions in developing countries that yield high or low rule of law levels can determine the ineffectiveness or effectiveness for attracting FDI. Hence, we look at the political capacity of a government at the provincial level as a political factor in attracting FDI in the three developing countries. 


\section{POLITICAL FACTORS}

1. Relative Political Capacity (RPC)

This variable has been used in many ways, from determining the correlation of economic growth at sub-national levels, to suggesting positive relations with population, fertility, and mortality rates. It is argued that it tests much better than traditional variables, such as military expenditures. Therefore, it is hypothesized that high levels of political capacity will be positively correlated with FDI.

\section{Democracy}

This dummy variable is included to gauge whether or not democracies and autocracies have an effect in attracting foreign direct investments. It is argued that democracies are a much freer society with traits such as civil liberties and civil rights given to the people to exercise without fear of arrest and/or persecution. Therefore, it is hypothesized that democracies will positively correlate with FDI.

\section{ECONOMIC FACTORS}

\section{Foreign Direct Investment (FDI)}

This is the main variable we are studying, and more importantly trying to find out how provincial governments attract FDI appealing to international investors that it is safe to conduct business. It is argued that high levels of FDI will lead to a stronger economy enabling the country to compete in the global market. 


\section{Gross Domestic Product (GDP)}

This variable has been argued to be a good proxy to measure the well-being of a nation. In addition, the data is readily available as it is computed by calculating the market value of all final commodities and services produced in a country, or in this case, a province. It is argued that higher levels of GDP improve the overall economy. Therefore, it is hypothesized that GDP will be positively correlated with FDI.

\section{Open Economy}

This variable is different in several ways as there is a scale that measures how close or open a province is depending on the three types of industry sectors in a country: Primary, which mainly consists of the mining industry, Secondary, which includes manufacturing, and Tertiary, which includes the financial and telecommunication sectors. Open Economy is used to measure the economic abilities of a country for potential economic development and foreign capital accumulation. Therefore, it is hypothesized that a country's economic openness will be positively correlated with FDI.

\section{DEFINITION OF CONCEPTS}

\section{Foreign Direct Investment (FDI)}

According to the Organization for Economic Co-Operation and Development (OECD), FDI reflects the objective of obtaining a strong interest made by a direct investor to an economy other than his/her. This interest implies the existence of a longterm relationship between both parties and their influence in the economy. Direct 
investment involves both the initial transaction between the two entities and all subsequent capital transactions between them and among affiliated enterprises, both incorporated and unincorporated.

The Bureau of Economic Analysis defines FDI as ownership or control, directly or indirectly, by one foreign person, or entity, of ten percent or more of the voting securities of an incorporated U.S. business enterprise or an equivalent interest in an unincorporated business enterprise.

\section{Relative Political Capacity}

There is very little research in this particular field of foreign direct investment at the provincial level in developing countries, which can be an advantage in the literature as the contributions for policy implications can be used to develop economies. It can also provide an intriguing insight for future researchers to invest their time and energy in this field, thereby improving the literature.

\section{Gross Domestic Product (GDP)}

According to the CIA World Factbook, GDP is defined as the value of all final goods and services produced within a nation in a given year.

\section{Democracy}

According to CIA World Factbook, Democracy is defined as a form of government in which the supreme power is retained by the people, but which is usually exercised indirectly through a system of representation and delegated authority periodically renewed. 


\section{Open Economy}

According to the World Bank, Open Economy is defined as the phase of a country's economic development where an industry grows faster than the agricultural industry, hence becoming the country's leading economic industry.

\section{METHODOLOGY}

To test the empirical model of the interaction between economic growth and political capacity, we utilized a regression analysis using a panel data on three developing countries: China, India, and Indonesia and its provinces (totaling eighty-nine provinces) from $1994-2000$. Although missing data is present due to the challenges of finding and collecting data at the provincial levels, we have a sufficient amount of observations in the model for this panel data.

\section{Dependent Variable: FDI}

This is the main variable that we are testing to determine its impact with respect to RPC and other economic and political variables. Previous researches have used FDI in a number of cases, such as Borensztien, De Gregorio, and Lee's work in 1998 where they argued that FDI can lead to strong economies for both the developed and developing countries. In addition, the economic growth literature provides very compelling for strong economies when the FDI stock is used (Feng 2003). The data will utilize the FDI stock of each provincial government as it can better analyze the accumulation of foreign capital overtime. The data comes from various sources, such as the National Bureau of Statistics of China, India Stats, and BPS-Statistics of Indonesia. 


\section{Independent Variables: RPC}

RPC is defined as the ability of a government to effectively extract resources from the population given their level of economic development (Arbetman and Johnson 2007). This variable is measured using a series of multiple regression models with certain indicators, such as taxes, natural resources, and exports to predict expected levels of extraction. RPC was developed to test the correlation among a wide variety of variables from economic growth to fertility rates (Arbetman and Kugler 1997, Feng 2003). This variable is unique in the sense that it is a measure of a government's ability to extract resources from its people to pursue policy goals. The important factor of this variable is the level of RPC, which a higher number indicates a more effective government's ability to extract resources.

\section{Gross Domestic Product (GDP)}

GDP provides compelling data for a country's ability to transact goods and services in a given year, and more importantly, a measurement of how well the nation is doing. This measure has shown consistency in correlation and significance, and has provided several indications of an emerging economy to potentially become an economic powerhouse. The data comes from several databases, namely the World Bank and IMF.

\section{$R P C * G D P$}

This is the key independent variable and is the driving force to this dissertation. This is the interaction between RPC and GDP, and is calculated by multiplying both variables. 


\section{Open Economy}

Open Economy is defined in various ways, from the liberalization of markets through non-tariff barriers in international trade, to the gradual involvement of various industries shaping the country's macro-economy (Vos et. al. 2002). The literature suggests that industrialization is positively correlated with economic development (Feng, Kugler, Swaminathan, and Zak 2008). There are several methods to measure Open Economy. The Heritage Foundation provides ten measures of industrialization ranging from Business Freedom to Freedom from Corruption, and each variable is measured based on certain indicators, such as quantitative data and surveys taken by experts, respectively. An alternate indicator of open economy is the expenditures made in certain sectors of the economy, namely mining, agricultural, manufacturing, financial/banking, telecommunications, and computer information, which all are grouped in the primary, secondary, and tertiary industries.

As a country becomes developed, it shifts its economy from the primary industry to the secondary industry and finally to the tertiary industry (Kane, Holmes, and O'Grady 2007). This is a good measure of an open economy as it is a sign that governments are spending money on certain items, such as establishing banks, improving telecommunications, and expanding infrastructure, thereby building trusts and relations with its people, and more importantly providing the confidence and safe haven for international investors to invest their capital. These industries are a great indicator of how advance a country's infrastructure is for development. 


\section{Control Variables}

To better test the empirical model without omitted variable bias, we have included a dummy variable. This variable has suggested strong correlations with respect to FDI in the literature, and could only improve the field by adding our dataset. Democracy has positively affected developing countries' economies to become self-sufficient, thereby becoming developed nations (Chakrabati 2001). In theory, Democracy is the best form of government as it allows the people to retain supreme power through an indirect system of representation. Democracy is a dummy variable and measured as ' 1 ' for Democracy and ‘0’ for Non-Democracy.

\section{ORGANIZATION OF RESEARCH}

The dissertation is broken up into five chapters. Chapter II will discuss an indepth literature review of the variables being used in this study to assist the reader a better grasp of the theories behind each variable. Here, we will discuss the effects of FDI at the provincial level in developing countries and determine whether if RPC alone is sufficient/insufficient, or if an interaction model needs to be present. Further, we hope to find that our findings can be used as a policy tool at the provincial levels of China, India, and Indonesia.

The methodology section will be discussed in Chapter III defining each variable and tracing the sources of data gathering. We will also explain the purpose of using a panel data and using the ordinary least squared (OLS) method as the quantitative tool of choice. Further, we will provide the results from the data in hopes to find correlation among the variables. This section will also discuss some of the issues that accompanies 
data gathering, specifically the lack of formal institutions that effectively records and maintains data at the provincial levels.

Chapter IV will discuss the empirical results of this dissertation shedding light to the importance of a developing country, and more importantly provincial governments and what sets of policies needed to effectively attract FDI into its economy. Lastly, Chapter $\mathrm{V}$ will discuss the implication and further discussion section hoping that developing countries will adopt the policy recommendations to improve its economy and compete in the global market. In addition, this section will highlight what can be done to improve the dataset for future researches, and perhaps how the data gathered and the quantitative method employed will positively contribute to the literature, thereby encouraging the next generation of scholars to expand the research of developing countries and find better ways to improve its economies.

\section{RELEVANCE OF STUDY}

The importance of provinces in developing countries to attract FDI for economic growth is dependent on several factors. However, the government will always have the last say in whether to implement or ignore economic and political policies, hence it is vital to point out which developing countries have the potential for policy changes as we cannot radically shift a government's structure overnight. Once we rule out a handful of developing countries, we can then prescribe our policies in hopes to attract foreign direct investments. Since FDI is a commonly used as an economic indicator to show the strength of a nation's economy, it is imperative that governments provide the necessary institutions that will foster policies to promote economic freedom and political stability. 
Developing nations that are willing to provide those safeguards should be courted by international investors. We hope that our findings from this study will suggest the importance of RPC and Economic Growth as an interaction variable as the main driving force in attracting FDI at the provincial levels in developing countries. 


\section{CHAPTER II}

\section{LITERATURE REVIEW}

The literature accounts for allocations of FDI from both an economic and political perspective as well as a combination of political-economic factors. Certain variables, such as economic freedom through the establishment of property rights and court systems have suggested strong correlations with FDI (Hanson 2005). In addition, other variables that could prevent or slow down investment opportunities, such as high levels of taxes, price controls, and corrupt governments can turn away investors and more importantly, FDI (De Soto 1989). It is vital to note the importance of this emerging field due to its dynamic of combining economical and political variables, thus making stronger arguments for correlation and analyses. And since this field is relatively new, there are an abundance of variables that have yet to be used in research and data collection. However, in the economic literature, there are several established variables that have been used in multiple researches suggesting consistent findings with FDI in both developed and developing countries.

Countries that experiences high levels of economic growth and increasing levels of GDP per capita suggests that its economy has ripened, which spillover into the global community leading international investors to invest their capital in the booming economy.

The most common economic variable used to determine the correlation with respect to FDI is economic growth rate. The ability of a country to experience consistent levels of economic growth leads international investors to want 'to join in the bandwagon' to extract the profits before it is too late. Hence, the growth rate of GDP 
exerts a small positive impact on inward FDI, which suggests that increases in the level of financial development, infrastructure development, and trade openness promote FDI (Ang 2008).

According to Borensztein et. al, FDI contributes more to economic growth relative to domestic investments in industrial countries and most developing countries. Figure 1 provides the chart for China between the years 1980 - 2000. However, take note after 1995 as FDI soared relative to domestic investments, hence explaining the increase in economic growth.

\section{Figure 1: China's FDI, DI, and GDP}

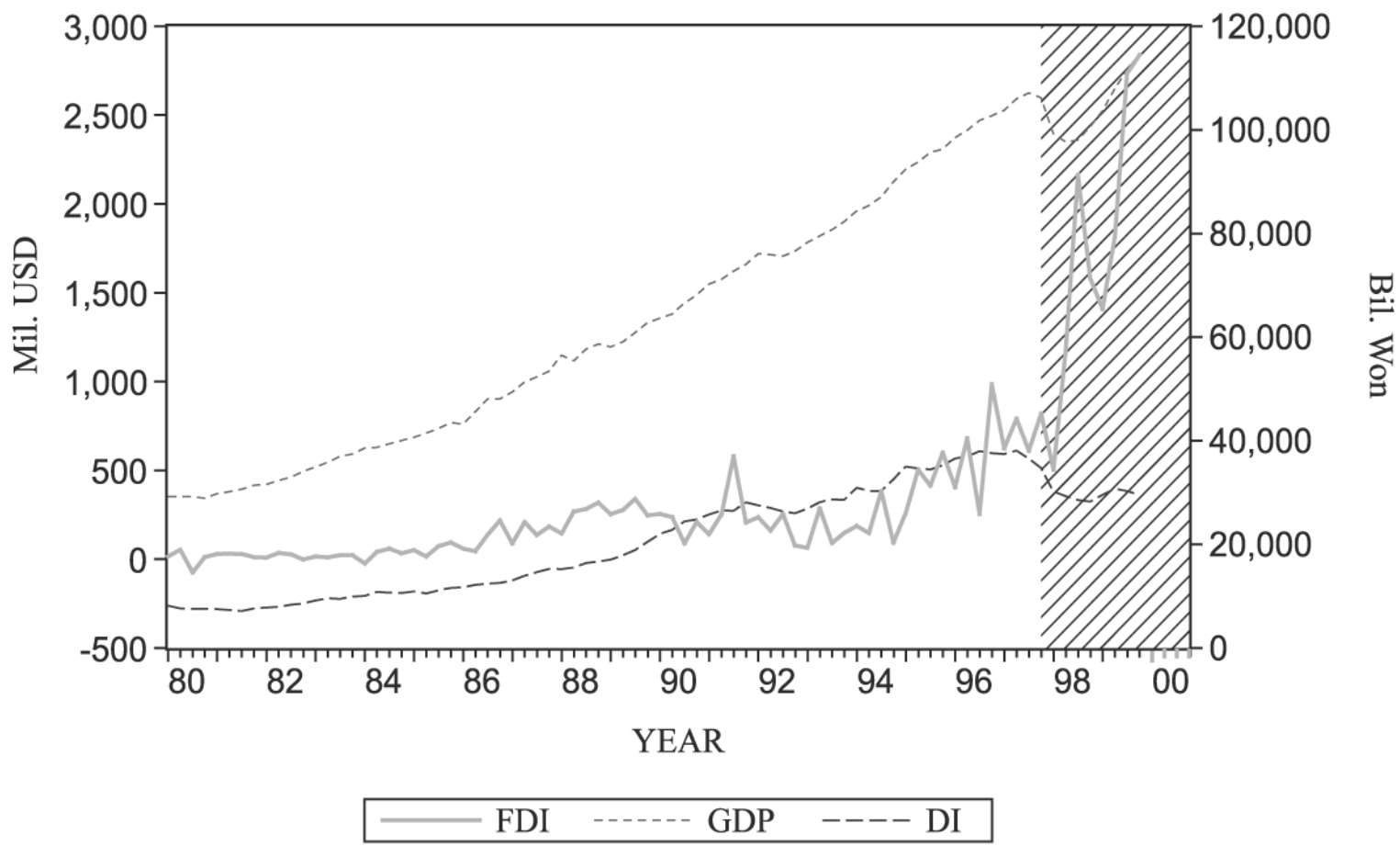

They looked at sixty-nine developing countries over twenty years, and utilized a cross-country regression framework suggesting that FDI flows is relatively more important than domestic investments in contributing growth. This is vital for any nation that wants to boost and improve its economic growth to be able to compete in the global market. It seems as if the traditional economic theory of building a strong foundation in 
only domestic investments is not enough to ensure a strong economy in this very small world. Thus, it is important for nations to understand one key element to the economic growth recipe, and that is to include foreign investments, primarily FDI as the main ingredient. Only then can nations experience higher levels of economic growth and eventually be able to finally improve the lives of its people. Another example of how FDI positively affects a nation's economic growth is the increase levels of its GDP.

The GDP is often an important measure of a nation's economic success or failure. Industrial nations, such as the United States have high levels of GDP, hence transforms a nation's title from developing to developed nation. This variable has traditionally been the cornerstone of economic theory to determine which nations are improving and lagging behind relative to each other. Since most economic theories, such as the Neoclassical growth theory and the Endogenous growth theory, although different inputs in the process of production, still assumes that GDP is the measurement of a nation's economic success. Studies have shown a strong positive correlation of FDI on a nation's GDP in both industrial and developing nations, along with the impact in regional areas. (Balasubramanyam et. al 1996). Figure 2 shows the correlation among the regional variables: GDP, trade, and FDI in China. There is a lot to be said about the effectiveness of FDI on GDP even at the provincial level. 
Figure 2: Regional Data in China

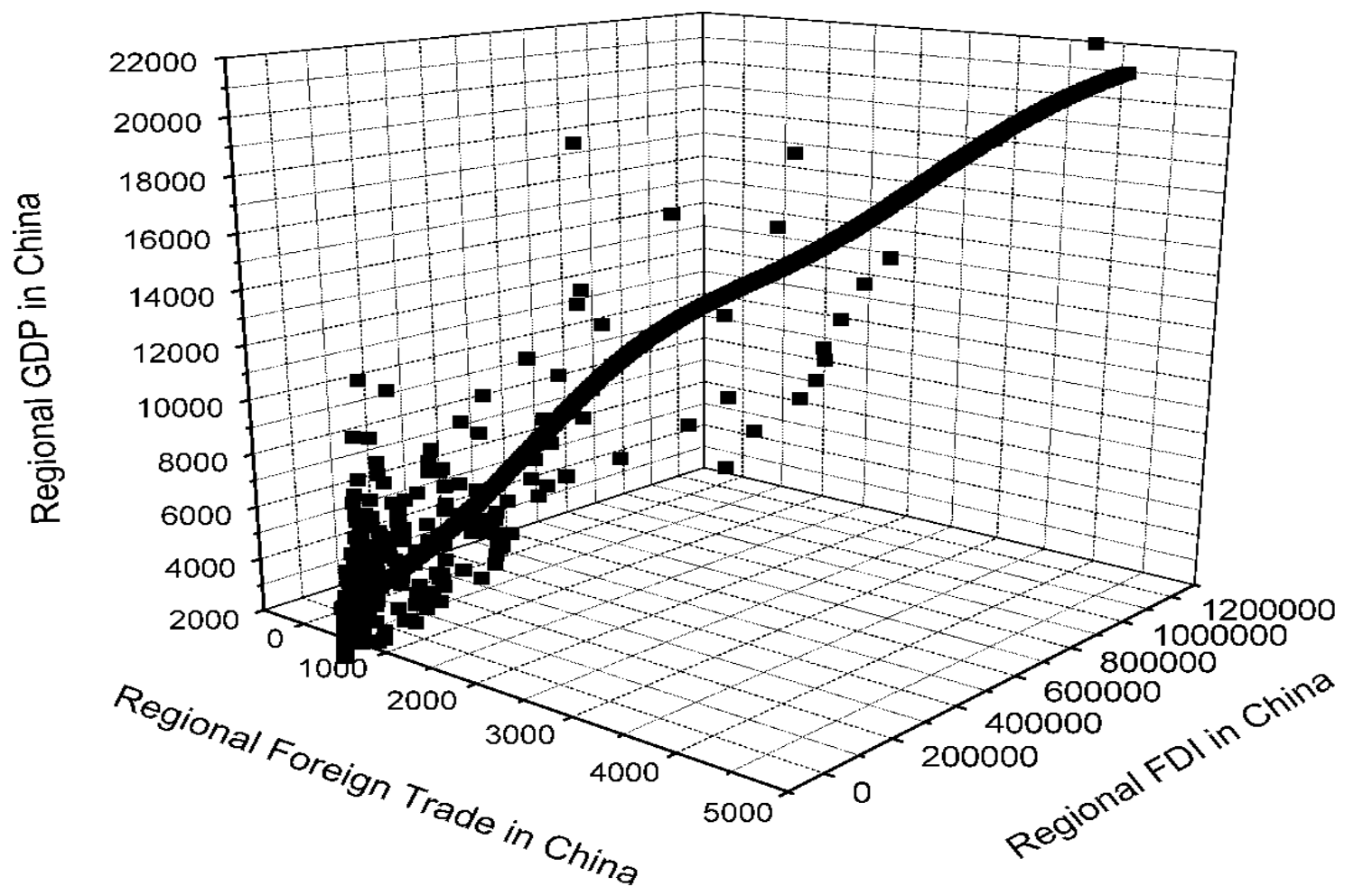

Other studies, such as the one conducted by Chowdhury and Mavrotas, suggested that it is GDP that causes FDI, hence an important variable to include. Both authors employed an extensive econometric methodology in three developing countries: Chile, Malaysia, and Thailand from 1969-2000. Figure 3 provides the time-series graph for FDI as a percentage of GDP. These three countries are heavy recipients of FDI and account for more than seventy percent. They implemented the Toda-Yamamoto causality test and found strong evidence, especially for Chile's GDP affecting FDI. Moreover, they also found strong evidence for a bi-directional causality between GDP and FDI for the Southeast Asian countries. There is growing evidence that both GDP and FDI are positively correlated. 
Figure 3: FDI as a percentage of GDP

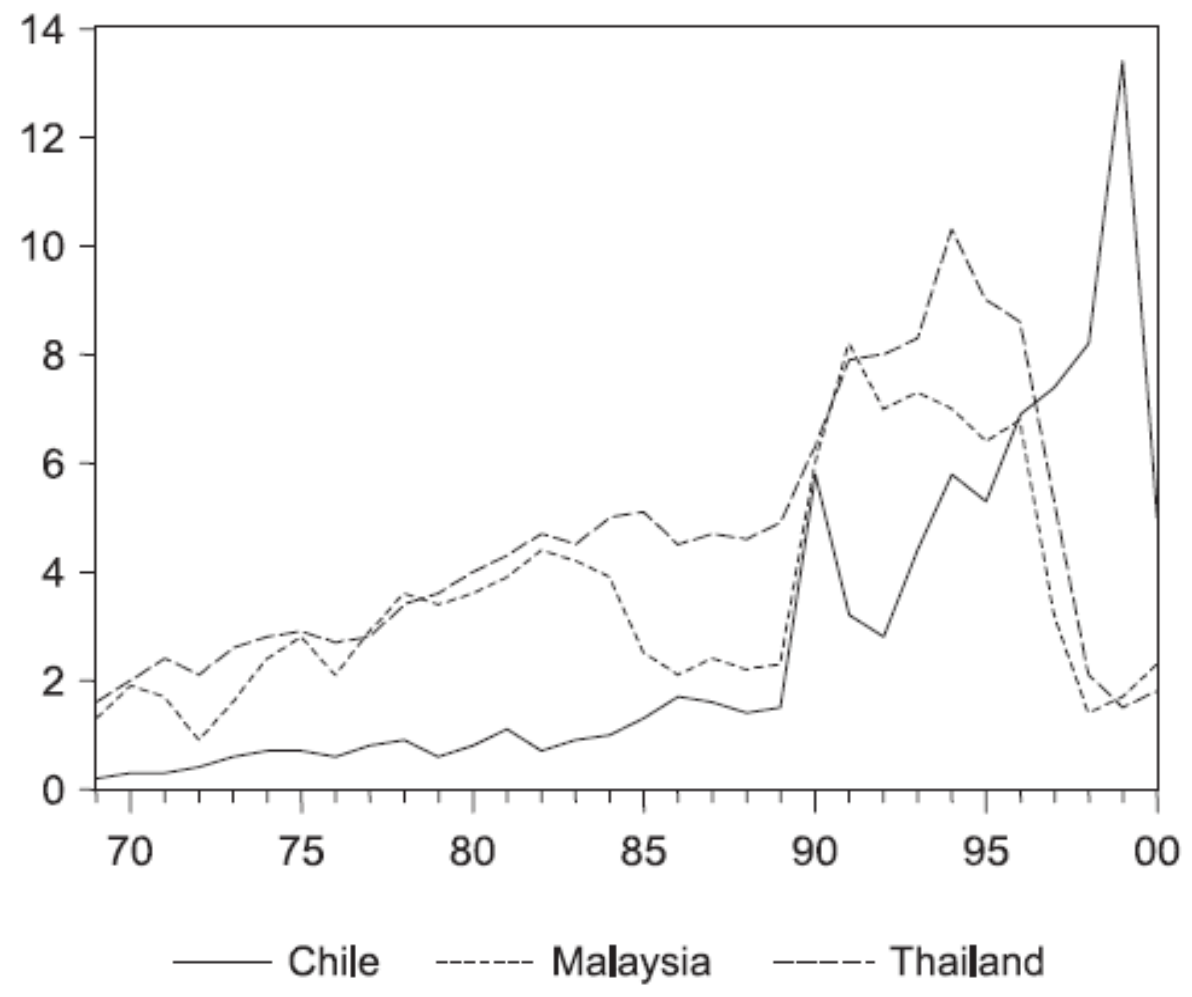

The privatization of public enterprises, particularly the service, manufacturing, and mining industries attracts FDI, as there are more opportunities for international investors to freely invest their capital in the free market system hoping to generate profit. We can call this an open economy. Nations with high levels of economic development are relatively considered safe countries to invest in providing a credible commitment to exchange goods and services between the host government and investors. Further, as a country privatizes its public sectors, it creates a more efficient and effective private infrastructure that can lead to governmental policies of poverty alleviation and job creation for its society enhancing the overall welfare of the country (Pamacheche and Koma 2007).

The ability for private institutions to privatize and invest in many developing countries with a supportive government has attracted high levels of FDI, such as in the 
case of Mozambique in the mid-1990s, which led to the production of domestic goods by private institutions and then exported to other countries on a tariff-free basis, thus allowing this once war-prone country to attract international investors (Lezard 2002). Moreover, the ability for a nation to allow private institutions to privatize its service, manufacturing, and mining industries can ensure efficient production through advanced technology, and research and development, but more importantly, minimize the levels of corruption that public institutions are tempted to pursue. According to Hellman et. al, a survey of twenty-two nations analyzed by the Business Environment and Performance Survey found no evidence of multinational institutions engaging in corrupt business practices than domestic institutions.

The service sector, usually seen as the most desirable industry by both domestic and international institutions is a good indicator of a nation's FDI level. Studies have shown that FDI invested in a nation's service industry increases its economy (Markusen 2000). Industrial nations have experienced rising levels of FDI, primarily in the manufacturing sector then in the service sector post-World War II leading to economic growth and stability. Industrial nations, once reaching economic prosperity, eventually saw an opportunity to cultivate the abundance of resources in developing nations, thus started the revolution of FDI into developing nations. Moreover, multinational corporations (MNCs) have increased their presence in developing nations for more than two decades, and will continue to be a vital player in a developing nation's economic endeavors (Lecraw 1977). The service sector has also accounted for a substantial portion of a nation's gross domestic product and employment rates making it a very lucrative industry for foreign investors. Today, more public and private institutions are outsourcing consumer services abroad, such as China and India to meet the needs of 
institutions' consumers as well as to efficiently cut overhead costs and wages (Enderwick 1989).

Another advantage of the service sector is the minimal storage of inventory that institutions that invest in either the manufacturing or mining industries must deal with. This advantage not only reduces inventory costs, but also enables a higher level of mobility transferring and/or opening service center locations. Further, with the advancement of technology, the Internet has truly shaped and revolutionized the communication medium of the world, and since the service sector does not necessarily involve commodities, the exchange of services can easily be attained via the Internet or other technological advancements. However, public and private institutions do not hastily invest its capital without formal research and thorough analysis of risk management in any developing nations. Institutions must be able to trust a developing nation's government from fear of political corruption and tyranny. Therefore, institutions invest its capital in a government that closely monitors its industry with regulation and enforcement, but with the freedom of free market capitalism. Thus, high levels of FDI can be found in credible developing nations, particularly in the service industries of telecommunications, banking, and transportation (Dunning 1989).

FDI theories also support the argument of institutions investing its capital in reputable developing nations (Wells 1981). It makes sense that once an industrialized nation becomes too costly to invest in, the willingness to relocate another business venture presents itself, thus enabling the investor to select a reputable developing nation. In addition, the low costs of resources in a developing nation, particularly labor can yield higher levels of return for the investor as in the case of Tunisia. A study conducted by the World Bank looked into developing nations, specifically Tunisia, a small country in 
the continent of Africa, and its ability to attract FDI in its service sector. The decision of the Tunisian government to reduce service barriers led to foreign investors competing among themselves to invest FDI in this once war-stricken developing nation.

This study revealed strong correlations of a credible government working with foreign investors to increase the levels of FDI in the service sector leading to economic growth (Konan and Maskus 2004). This comes to show a good example of a developing nation with the potential to improve its economy through policy changes in its governmental structure can truly attract foreign investments in all sectors equally.

Another important sector attributed to the increase of a developing nation's economy is the manufacturing industry. There are some advantages of FDI in this sector, such as the low costs of producing a commodity relative to production in an industrialized nation. In addition, the literature does provide strong evidence of FDI in developing nations' manufacturing industries that lead to improvements of economic growth. A good example of this case is Mexico. Besides its geographic location, Mexico collaborates with its northern neighbors in many business ventures, primarily the North American Free Trade Agreement (NAFTA), which is an agreement signed by all three North American governments creating a tri-lateral trade bloc to utilize the resources each nation possess most of. Since 1992, many corporations from both Canada and US have relocated its factories in Mexico for the purpose of minimizing overhead costs and maximizing profits. Figure 4 provides an example of how NAFTA became an important market for U.S. exports of agricultural goods. 


\section{Figure 4: U.S. Exports of Agricultural Goods}

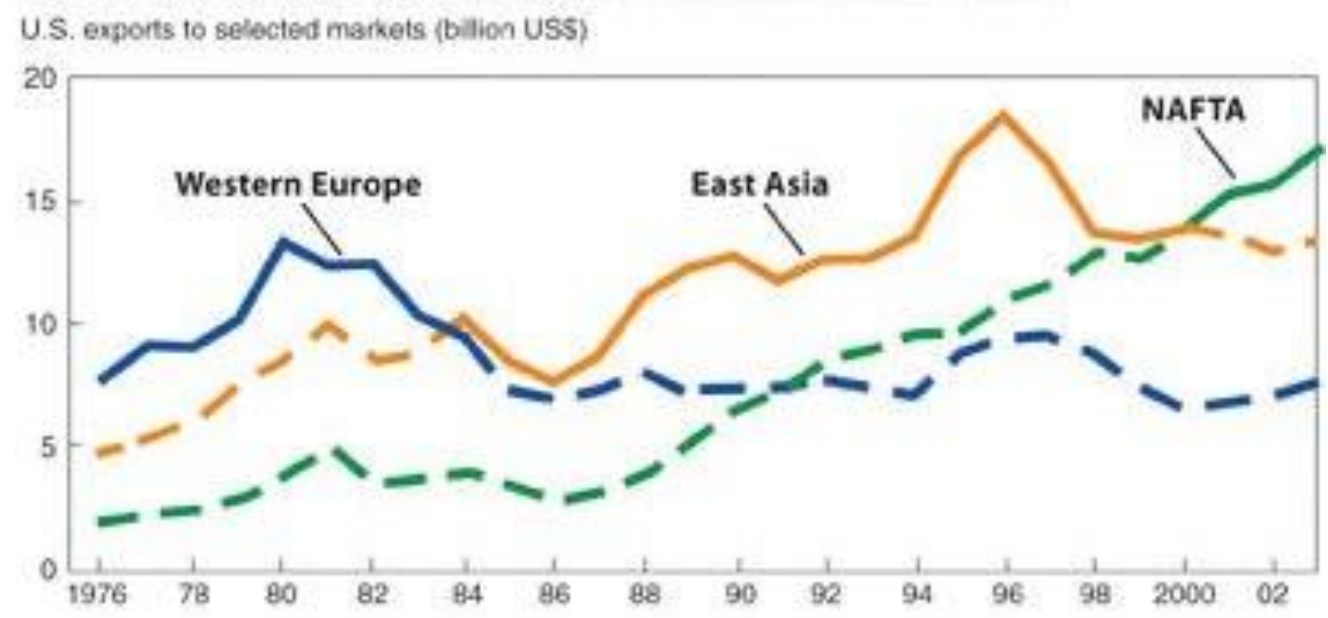

The Mexican economy has experienced an improvement in its economic growth at a rate of $15.5 \%$ since the ratification of NAFTA in 1994, primarily in its manufacturing sector as these so called Maquiladoras are able to import raw materials and produce goods for exports (Hufbauer 2005). Figure 5 provides the graph of Mexican manufacturing from $1987-2005$.

Figure 5: Mexico's Manufacturing Output

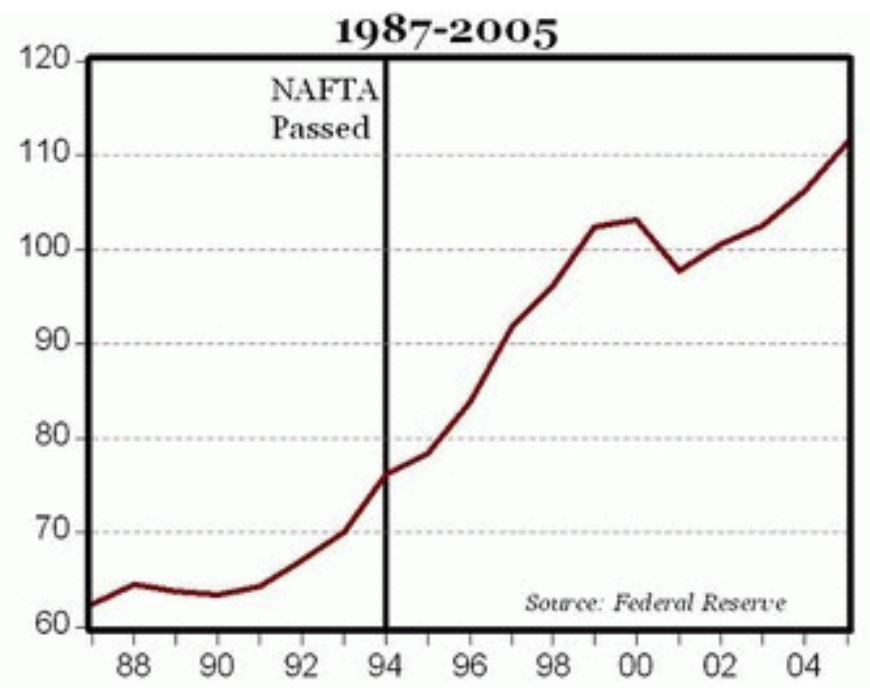

Despite Mexico's corruption perception index rank of 72 out of 180 countries, its government structure is closely similar to that of the US, which includes three branches 
of government and a separation of powers. This type of government structure has already established itself as a true model of a government worldwide, and is the choice for most industrialized nations to implement in developing nations. Mexico's DemocraticRepublic government has set forth its credibility in the international community as a reputable country to conduct business with, especially since the NAFTA ratification. Foreign investors do feel confident that their FDI will be safe and more importantly, protected from political corruption and tyranny. This is just one of the many examples of how a developing nation can improve its economy through attracting FDI in its industries with strong institutions. However, the last sector has been a popular topic for debate whether it does lead to an improvement of economic growth, or if it is a curse yielding high levels of political corruption and tyranny.

The mining sector has been seen as a catch twenty-two, in that depending on the developing nation it can reap positive or negative economic gains. It is also determined whether there are strong institutions present or absent in a developing nation. Nevertheless, a wide array of literature in the resource curse theory has been examined by both sides of the aisle with surprisingly different results. However, both proponents and opponents of this theory did share one common denominator, which essentially determined a cursed or blessed government.

The proponents of this theory have argued that a developing nation's abundance of resources can actually impact its economic potential and slow down economic growth (Sachs and Warner 2001). Numerous case studies of developing nations have been observed and conclude that the abundance of resources correlates with high levels of corruption, thus low levels of economic activity. An example of this phenomenon is the forest industry in south Asian countries where rentier states are common, which in turn 
charge foreign investors high levels of rent for extracting its resources, thereby increasing the levels of collusion among public leaders (Ross 2001). This combination can prove to be detrimental to a developing nation's ability to sustain economic growth as the temptation of public leaders to continually increase rents from foreign investors will only hamper the free market system leading to inefficient business practices. Moreover, this inefficiency will host an unfavorable environment for the populace as collusion is likely to occur from unethical practices, thus creating a small set of cronies that receives the private goods intended to be redistributed to the public. While proponents argue that the resource curse theory is inevitable in developing nations with an abundance of resources, proponents counter these arguments by focusing on one key factor.

Opponents of the resource curse theory have found a negative relationship between developing nations' abundance of resources and the strength of its institutions. The rent-seeking literature provides a good explanation of the resource curse theory in that scholars argue that a developing nation with an abundance of resources, plus the inclusion of weak institutions will lead to corruption (Krueger 1974). Therefore, there is a consensus in the field that the resource curse theory can be beneficial to a developing nation with an abundance of resources if and only if strong institutions are present. Otherwise, the developing nations with weak institutions will only experience higher levels of corruption. This key factor, institutions proves to be vital in the resource curse literature as developing nations that can strengthen its institutions, such as enforce the rule of law will minimize rent-seeking activities, which is an ingredient to the corruption recipe (Bhagwatti 1984).

In essence, both proponents and opponents of the resource curse theory can agree that with the presence of strong institutions, corruption can be minimized in a developing 
nation. The argument makes sense as strong institutions, such as the rule of law will make it more challenging for public leaders to rent resources in the mining industry to foreign investors without the consent of the people. Further, strong institutions enable a check and balance system as corrupt public leaders that are exposed committing unethical activities can face political turmoil be it impeachment and/or conviction. Hence, the costbenefit analysis for a public leader to uphold and abide by the rule of law is greater than the cost of political suicide.

Although developing nations will not always dramatically restructure its governance and rule of law overnight, there have been a few examples of developing nations that took the extra effort and experienced economic growth. Botswana, a small southern nation in the African continent is a democratic republic. Since its declaration of independence in 1966, it has experienced high levels of economic prosperity due to its abundance of resources, such as diamonds, gold, and uranium. However, it has been able to minimize corruption low relative to its neighboring countries due to its strong institutions governing the rule of law, thus it has been a model for all African countries to adopt and emulate (Acemoglu et. al 2002). Here is one clear winner that both proponents and opponents of the resource curse theory can agree on. Botswana is a successful developing nation with an abundance of resources, but able to retract the temptation of rent-seeking activities due to its strong institutions. In essence, the resource curse theory applies to developing nations that have weak institutions where the rule of law is low or absent (Mehlum et. al 2006). Most scholars agree that a developing nation's rule of law definitely is an important variable in attracting FDI and experience economic growth, but many argue how it is defined and measured. 
The total population of a country can be utilized as a rough estimate of potential consumers to purchase products and services manufactured by foreign direct investment (Banga 2003). The combination of increasing levels of GDP per capita and total population could provide an incentive for investors to find a target market in the country, thereby cutting some costs from exporting goods abroad. A population that experiences rising levels of income attracts foreign capital accumulation. Recent studies, such as Feng's (2003) empirical work on political institutions show political variables with respect to FDI can explain the attraction of foreign capital in developing countries. In addition to the extent of economic literature, there is also an established political literature on FDI. Recent studies focusing on governmental corruption through bribes and extortion have provided the framework on FDI suggesting an inverse relation (Kaufmann, Kraay, and Mastruzzi 2008). Hence, it is essential for any country to establish a government, regardless of ideology or political structure that is accountable to the people. For example, some governments choose to take the road to democracy are more likely to promote individual freedoms, civil liberties, and civil rights. In such societies, constitutional laws ensure protection for investors from arbitration making a much more favorable environment for investments. The ability of a government to uphold these laws can be related to increased FDI levels suggesting that a stable political environment is less likely to experience political coups or revolutions (Harms and Ursprung 2002). The FDI literature sheds light to multiple political variables that show strong correlations with economic growth. Scholars argue that for developing nations to experience positive levels of economic prosperity, its institution must adopt and enforce certain practices. Some examples include implementing a constitution that gives civil liberties to its people as it is seen as the main organ of a free nation. Other examples 
include a restructuring of government into a democracy where the populace is free to vote for the persons to represent them. This is more of the popular belief in the literature as we have seen countless public leaders, such as U.S presidents who implemented their presidential doctrines to democratized developing nations. Other theories, such as the Democratic Peace theory also supports this argument that peace can be achieved between democratic nations due to the populace's recognition that wars destroys economies, thus being able to concentrate on its economy through the free market exchange. Lastly, some scholars argue that a developing nation can be non-democratic and still be able to attract FDI to increase economic growth. However, the key factor in the latter argument is that these developing nations must have low levels of corruption in their country to be able to attract foreign investors.

Lastly, a government's political capacity is the most important indicator for attracting FDI. The government's ability to extract resources from its people, such as taxes, can provide its society with a better financial system, hence developing its economy. Recent studies have shown a consistent trend of political capacity and economic growth (Feng 2003), while other studies measure the levels of political extraction and political reach in sub-national levels suggesting positive effects on FDI (Johnson 2007). They report that political capacity is statistically significant with both economic and political variables, and might be a better measurement than traditional factors, such as GDP and military expenditures (Singer 1960). Further, a wide range of researches have allowed the popularity of political capacity to be used in many sub-fields, such as population, fertility, and mortality rates (Kugler, Feng, and Zak 2000) reporting consistent findings. In addition, political capacity has been used in testing a government's ability to decrease inflation (Alacazar 1997) as well as its ability to 
implement a wide range of policies (Snyder 2000). This reassures investors that their capital is protected by a financially-sound market system reinforcing the notion of a strong and stable political system. Political capacity is indeed very dynamic and powerful, and could be the key to finally solve the puzzle of what attracts FDI in developing countries.

As a nation establishes a constitution that is accountable to its people and promotes individual freedoms ensuring protection from arbitration, it becomes a viable recipient of foreign investors. The ability of an institution to uphold the rule of law, such as strong civil liberties has enabled consistent flows of FDI due to the likelihood of a stable political environment that will not lead to coups or a revolution. In addition, financial institutions appear to be attracted by countries in which civil and political freedoms are respected (Harms and Ursprung 2002).

The rule of law can also be extended through a developing nation's willingness to provide transparency. For an institution to be able to provide the public access to its records of public funds is an important first step to invite foreign investors. This will then enable investors to have a peace of mind knowing that the FDI invested into the nation will not be used for personal gains, rent-seeking, or special interests. Hence, it is up to the government to uphold and sustain a greater sense of transparency to financial institutions as there is a credible commitment involved among the parties (Cerdenia 2001). Moreover, this makes the government accountable to its people by screening financial institutions, such as multinational corporations (MNCs) that are credible and reputable in investment standards minimizing the likelihood of corrupt practices. The rule of law encompasses many attributes within an institution, but some scholars argue that the rule of law has a small affect in the overall outcome of economic prosperity. 
There have been several case studies that show democratized nations are able to attract FDI and increase levels of economic growth, but for the most part, a democratized nation does not guarantee strong institutions to enforce the rule of law. The notion that a democracy is a sufficient reason to invest in should be of concern as we have seen many examples of developing nations that have democratized for the sake of democratization, but with weak institutions. 


\section{CHAPTER III}

\section{METHODOLOGY}

In order to understand the data set, we tested three developing countries' provincial governments from 1994-2000. The collection of data proved to be quite challenging as there were several occasions that led to simply nowhere. China, India, and Indonesia were chosen for its diverse set of political and economical policies as well as their strengths as future global superpowers. There is a growing consensus that the Asian continent is starting to show its prowess and ability to dominate the international markets. It will be a matter of time for each of these countries to take its rightful place on the throne.

We employed an Ordinary Least Squared (OLS) regression to determine the correlation of variables. We have a sufficient amount of observations collected and also feel sufficient to carryout this research, especially considering the lack of literature in the sub-national field. We found interesting results only to reinforce our hypothesis that an interaction between a country's RPC and an economic variable is needed to attract FDI.

We can expect to run several models using FDI as the dependent variable and hope to find consistency throughout the regression analyses. We expect to conclude that RPC alone in these three countries is not enough to attract FDI, rather there needs to be an interaction between FDI and economic growth to do so. However, there are several works in the RPC literature that provides the framework of the importance of RPC as an independent variable alone, such as the works from Kugler, Feng, and Zak with their POFED model, and Arbetman and Johnson, so we must acknowledge the importance of RPC as a dynamic variable. Nevertheless, there are the works of Kugler and Cohen who 
have provided their model similar to ours in that RPC alone is insufficient in effectively attracting FDI, hence an interaction variable is needed.

An issue worth considering is the sub-national data each provincial government represents. The argument here states that provincial governments may not have the wherewithal needed to effectively carryout political and economical policies in attracting FDI. Examples of this would be an incompetent government that is able to collect resources, such as taxes from its people, but does not in turn use their extraction to create a lucrative economic environment for investors. This would be a disincentive for potential investors to invest its capital as there is no assurance of a safety net for investing.

Our first model will include all three developing countries and its respective provincial governments. We will analyze the independent variables to assess its effectiveness on FDI, primarily the interaction variable between RPC and GDP. The interaction variable is very important as it can provide compelling analyses in terms of policies to developing countries. We hope to find this variable both positive and highly significant, thereby stating that RPC alone is insufficient for provincial governments to attract FDI, rather needs to interact with an economic variable to make a more favorable investing environment.

The interaction variable is one of the highlights of this research as there is consistency from the works of Kugler and Cohen in their interaction model. Further, it provides the tools necessary for provincial governments in developing countries to achieve their goals of economic growth and stability. The interaction should suggest that these governments have both the political and economic policies in place, thereby effectively extracting the resources from its people, but being able to implement 
economic policies that improves the overall welfare of the province. This is truly a favorable environment for investors to consider investing in as there are assurances that a government will not promote corrupt acts, default on its loans, and/or implode through civil unrest. We have seen numerous examples of developing countries throughout the world with one or more of these attributes, from Tunisia to Libya, among others.

The next independent variable is GDP. We expect to find a significant and positive correlation between FDI and GDP, thereby supporting the growth literature. Many studies, such as Feng's work has tested the ability of developing countries' strength of GDP in determining the likelihood of attracting foreign investments. If GDP is stable and growing, it is a very good sign that the overall welfare of a country is improving, thereby sending credible signs of sound economic policies to the international community.

The next independent variable is Democracy. We expect democracy to support the growth literature as well considering that it is the type of governmental system that gives supreme power to the people, hence we expect high levels of civil liberties and civil rights, which are very appealing to international investors. However, it is important to note that there are many types of democracies, so this type of governmental system varies from country to country. We see a good number of democracies in the world, but are not necessarily free in terms of civil liberties and civil rights, so we need to take this into account. Not to mention the differences between developing and developed nations can also impact its abilities to effectively attract FDI, so democracy can either help or hurt an economy depending on many political and social attributes. Nevertheless, a country considered to be non-democratic might have more of a challenge in effectively attracting FDI. Moreover, a country that chooses to democratize itself without the proper 
institutions can lead to a stagnant government does not invest in its human capital system, thereby severely dampening its economic opportunities. A good indicator of this is the increasing poverty levels of a province. Again, a government can effectively extract resources from its people, but if it chooses to pursue personal policies and reward cronies through private goods then it becomes a disservice for economic growth. We see a lot of examples similar to this, especially that of African nations, such as Zimbabwe where poverty levels are on the rise not to mention its uncontrollable inflation rates and its current dictator, Robert Mugabe. We want to prevent a developing country from becoming a democracy like this as it will only hamper its economic abilities.

We hope to find democracy to be significant and positively affecting FDI. There is also the possibility of several provinces in each country that is remotely isolated from traditional urban and metropolitan areas where governments do a much better job exercising democracy through elections and social services. In addition, provincial governments that are hundreds of miles away from the closest urban area might fall into the category of tribal governments with its own rules of laws. This can lead to the extraction of resources, but in an ineffective manner as tribal leaders may have little incentive in implementing political and economical policies. Further, we expect to see a consistency in the literature that urban and metropolitan areas do exercise democracy much more effectively, such as the growing levels of education attainment and income per capita for both men and women versus that of rural areas. We see two metropolitan provinces that epitomize these indicators: Beijing and Guizhou.

The last independent variable included in the first model will be Open Economy. Our model takes into account the levels of a country's ability to privatize its primary, secondary, and tertiary sectors. We have created a continuum model to gauge exactly 
where each provincial government belongs to by looking at its total expenditures in each privatize sector.

Figure 6: Issue Continuum for Open Economy

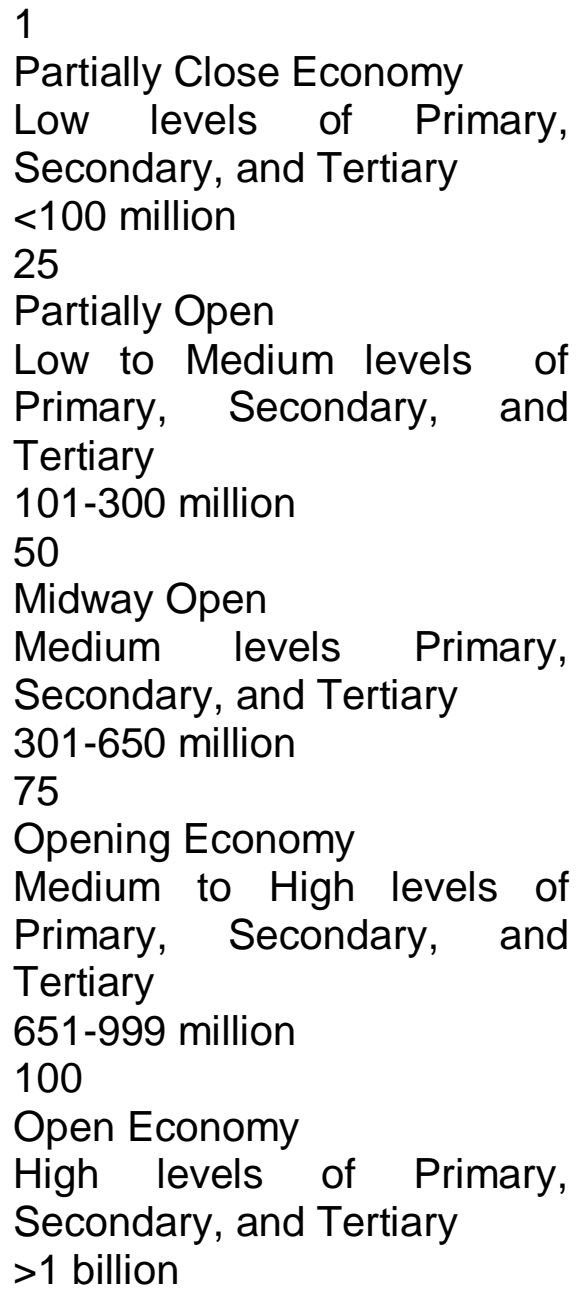

Depending on how much each province spends on privatization, whether mining, manufacturing, and/or services, they will determine the level of economic openness. This is very important for many reasons, especially to investors as they want to ensure that their investments are in a safe place with the hopes of high returns, so it is no surprise to see provinces with an open economy levels of 75-100 attract the most FDI. Another reason why this is important for economic development is because a country's economic 
openness can determine how ineffective/effective its government is governing. An open economy level indicator of 75-100 provides the substance that the ruling government in a developing country is at best trying to implement effective economic policies to jumpstart its economy, thereby putting its resources in industries such as its mining, manufacturing, and/or services sectors.

These attempts indirectly send the credible commitments to investors that it is perfectly safe to put their capital in a country. We would like to see each provincial government with levels of 75-100, but many provinces find themselves in remote areas where infrastructures are absent not to mention low levels of RPC, which signifies an ineffective governance of the ruling party. We hope the model supports the literature that economic openness is a good indicator in attracting FDI.

The next model will break down each individual country in the following order: China, India, and Indonesia. We hope to find consistency with all three countries in that RPC alone is insufficient in effectively attracting FDI, but needs an interaction with an economic variable. We also hope that the other independent variables will be consistent and support the literature. We expect GDP to be positive and significant in each developing country as they have proved to be a rising and dominant force in Asia, especially considering that all three countries combined has a GDP value of over fifteen trillion dollars, which is more than the U.S. It should be no surprise to see how these three countries are improving the standard of living for its society as we have seen its gross domestic product per capita (GDP per capita) also rising. However, with that said, we have to take note of how different each country is in terms of political and economic history, and how each developing country has gotten where they are today. 
We also expect to see Democracy consistent with our first model, so this is where the developing countries differ. We expect to see our China model to have a negative correlation between FDI and non-democracy as the expectation in the field is that democracies are the better form of government allowing supreme power to rest in the hands of the people. In addition, we know that India is the largest democracy in the world with well over 1.1 billion people and growing, and Indonesia is the most populous Muslim country in the world, so both should have no problem attracting FDI due to its democratic style of governing. Although China is non-democratic nationally, we know its provincial governments exercise a larger degree of democracy than usual. We see provincial governments, such as Guangdong and Jiangsu with tremendous amounts of FDI as two dominant cities: Hong Kong and Shanghai have attracted international investors to continually invest capital pursuing new venture projects.

Lastly, we expect Open Economy to be consistent with our first model as it is a compliment in what it takes to effectively attract FDI. It would be nearly impossible and shocking to find provincial governments with closed economies attracting foreign investments. Rather, we assume that international investors tend to be more risk-averse, especially during challenging financial times like what we are experiencing today, hence would not consider investing in a developing country with a closed economy. Plus, a partially closed economy indicates that the ruling government has little or no interest in importing and exporting goods and services to other countries, so it is very rare to find true closed economies nowadays. This would truly be a disincentive for international investors as they themselves would be very limited to what they can, and more importantly, cannot do in that developing country. 
Overall, we hope to find consistency in our models with the correct theoretical signs and high significance levels as this would prove to be vital as a policy tool that developing countries can adopt and implement in its efforts to effectively attract FDI. 


\section{CHAPTER IV}

\section{RESULTS}

Our analyses imply that RPC alone does not necessarily attract FDI in provincial governments of developing nations, but rather RPC needs another variable, more precise, an economic variable to effectively appeal to international investors. Therefore, we added GDP as an interaction variable with RPC, and found interesting results. Our models suggest that this interaction variable is very viable in attracting FDI as it is both positive and significant for all countries as well as for each individual country. Further, our analyses imply that developing countries can effectively attract FDI so long as their governments extract resources from its people to promote economic policies improving the overall welfare of its province.

Model 1 includes FDI as the dependent variable, while GDP, RPC*GDP, Democracy, and Open Economy are the independent variables. Model 1 provides the following.

\section{Model 1: All Countries}

- regress FDI GDP RPCGDP Dem open

\begin{tabular}{r|crr} 
Source & SS & df & MS \\
\hline Mode1 & 7089577.92 & 4 & 1772394.48 \\
Residua1 & 5603705.53 & 485 & 11554.032 \\
\hline Tota1 & 12693283.4 & 489 & 25957.6349
\end{tabular}

Number of obs $=490$

$F(4,485)=153.40$

Prob $>\mathrm{F}=0.0000$

R-squared $=0.5585$

Adj R-squared $=0.5549$

Root MSE $=107.49$

\begin{tabular}{r|rrrrrr}
\hline FDI & Coef. & Std. Err. & $\mathrm{t}$ & $\mathrm{P}>|\mathrm{t}|$ & \multicolumn{2}{c}{ [95\% Conf. Interva1] } \\
\hline GDP & 35.70257 & 6.554204 & 5.45 & 0.000 & 22.82443 & 48.58071 \\
RPCGDP & 12.56402 & 7.069351 & 1.78 & 0.076 & -1.326316 & 26.45436 \\
Dem & 44.00503 & 14.9763 & 2.94 & 0.003 & 14.57858 & 73.43147 \\
Open & .5768624 & .290895 & 1.98 & 0.048 & -0052923 & 1.148433 \\
-COns & -71.52573 & 15.17239 & -4.71 & 0.000 & -101.3375 & -41.714 \\
\hline
\end{tabular}

Model 1 includes all provincial governments from the three developing nations:

China, India, and Indonesia. It is no surprise to find GDP to be positive and significant, 
which supports the growth literature as developing nations try to make strides in the international community to become an economic powerhouse. We find that a one percent change in GDP will lead to a thirty-five million dollar increase to FDI. Our three developing countries have done very well as we see China with a GDP of over ten trillion dollars, while India with over four trillion dollars, and Indonesia with over one trillion dollars. The International Monetary Fund also ranks each country overall as number two, five, and fifteen, respectively hence we can expect GDP to continue to be an effective variable in attracting FDI. Moreover, our results indicate that fifty-six percent of the variance is explained, which is a good sign that our variables do indeed have an impact on FDI.

Model 1 excluded RPC as it was negative and insignificant implying that governments with high levels of extraction detract FDI and does not necessarily impact economic policies. Figure 7 provides the regression analysis.

Figure 7: Model 1 Including RPC

- regress FDI RPC GDP RPCGDP Dem Open

\begin{tabular}{|c|c|c|c|c|c|c|c|}
\hline Source & ss & $d f$ & \multicolumn{2}{|c|}{ MS } & & \multirow{3}{*}{$\begin{array}{l}\text { Number of obs } \\
\text { F( } 5, \quad 484) \\
\text { Prob }>F \\
\text { R-squared } \\
\text { Adj R-squared } \\
\text { Root MSE }\end{array}$} & \multirow{3}{*}{$\begin{array}{rr}= & 490 \\
= & 122.50 \\
= & 0.0000 \\
= & 0.5586 \\
= & 0.5540 \\
= & 107.59\end{array}$} \\
\hline $\begin{array}{r}\text { Mode1 } \\
\text { Residual }\end{array}$ & $\begin{array}{r}7090312.95 \\
5602970.5\end{array}$ & $\begin{array}{r}5 \\
484\end{array}$ & $\begin{array}{l}141 \\
115\end{array}$ & $\begin{array}{l}2.59 \\
3853\end{array}$ & & & \\
\hline Total & 12693283.4 & 489 & 259 & .6349 & & & \\
\hline FDI & coef. & std. & Err. & $t$ & $P>|t|$ & [95\% Conf. & Interval] \\
\hline $\begin{array}{r}\text { RPC } \\
\text { GDP } \\
\text { RPCGDP } \\
\text { Dem } \\
\text { Open } \\
\text { cons }\end{array}$ & $\begin{array}{r}-3.179844 \\
34.64317 \\
13.83407 \\
44.2538 \\
.5731089 \\
-68.46979\end{array}$ & $\begin{array}{l}12.6 \\
7.792 \\
8.687 \\
15.02 \\
.2915 \\
19.4\end{array}$ & $\begin{array}{l}5194 \\
103 \\
737 \\
325 \\
571 \\
5352\end{array}$ & $\begin{array}{r}-0.25 \\
4.45 \\
1.59 \\
2.95 \\
1.97 \\
-3.52\end{array}$ & $\begin{array}{l}0.801 \\
0.000 \\
0.112 \\
0.003 \\
0.050 \\
0.000\end{array}$ & $\begin{array}{r}-27.97542 \\
19.33264 \\
-3.236266 \\
14.73494 \\
.000235 \\
-106.6576\end{array}$ & $\begin{array}{r}21.61573 \\
49.9537 \\
30.90441 \\
73.77265 \\
1.145983 \\
-30.282\end{array}$ \\
\hline
\end{tabular}

Therefore, RPC needs to be combined with an economic variable. The interaction variable between RPC and GDP is positive and significant. We found that a one percent change in the interaction variable of RPC*GDP will increase FDI by twelve million dollars. This implies that governments that effectively extract resources from its people 
needs to do so in a manner where the economic policies are geared towards increasing the living standards of its country; this is what will appeal to international investors. It is not enough to simply collect taxes on a regular basis and expect FDI to flow into the economy as there is no commitment made by the government to improve economic development. International investors are smart and will see right through a government failing to make these commitments.

We see this interaction variable as a necessary step in enabling provincial governments to effectively attract FDI. This becomes a very important policy tool for many developing countries as it provides them an opportunity to participate in the international economy of foreign investments. We do not have to expect a country to simply experience a revolution and/or conduct a political coup to remove the current government; rather we need to see the current government make a commitment in improving the living standards of its people. This would suffice the ability to appeal to the international community as a credible country thereby attracting FDI. We have also found that an open economy is an important determinant in attracting FDI.

An open economy allows several things to occur, namely the exchange of goods through both imports and exports to the international community, and also, the credible signal to international investors about the opportunities for maximizing growth and profits. We found that a one percent change in an open economy will lead to a five hundred thousand dollar increase to FDI. This is consistent with the literature as we find open economies a better and safer place for investments than closed economies. In addition, international investors would not risk their capital knowing that a developing country has not opened up its borders to trade as the incentives in doing so is absent; why 
risk the possibility of zero returns in a closed economy where the likelihood of an authoritarian regime exists?

Moreover, our analysis suggests that the type of governmental system does matter when attracting FDI as our results suggests that autocracies have a negative impact than do democracies. We find that a one percent change in democracy will lead to a forty-four million dollar increase to FDI while a one percent change in autocracy will lead to a seventy-one million dollar decrease to FDI. We see China as a communist style country ruled by an authoritarian regime while both India and Indonesia's governmental systems are considered to be a democratic republic. However, we should take note that China is very different compared to the average communist style authoritarian system, such as Laos and Vietnam. Where China is a massive growing nation with record level growth rates, military and technological capabilities, Laos and Vietnam are plagued with high levels of corruption and political instability.

Since our variables vary in terms of measurement, it is important to note that we need to include standardized coefficients to better assess our model. Figure 8 provides us model 1 with beta coefficients.

Figure 8: Model 1 with Beta Coefficients

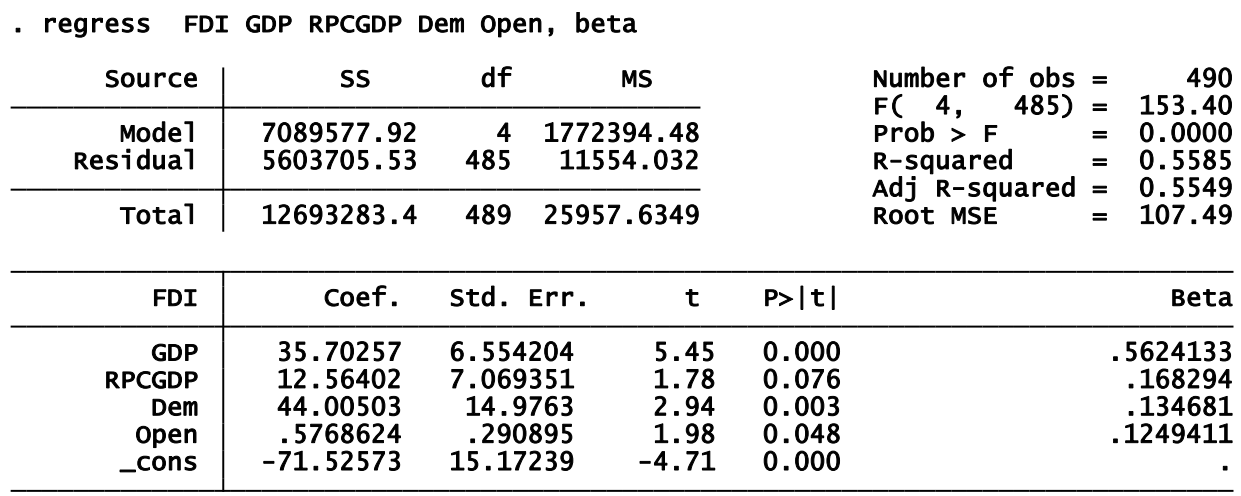


It is expected that GDP does have the strongest weight on FDI at 0.56 relative to the other variables, but one interesting point to make is to note the interaction variable at 0.16 , which is higher than the other variables of Democracy and Open Economy, 0.13 and 0.12 , respectively. This again highlights the importance of the interaction variable as a powerful tool to influence FDI at the provincial level of a developing county.

Now, let us take a look at each of the variables in a graph format to determine the effectiveness of the dataset. From a snapshot picture, we can see the correlation matrix for all variables regressed from Model 1, and notice some interesting things.

Graph 1: Correlation Matrix of Model 1

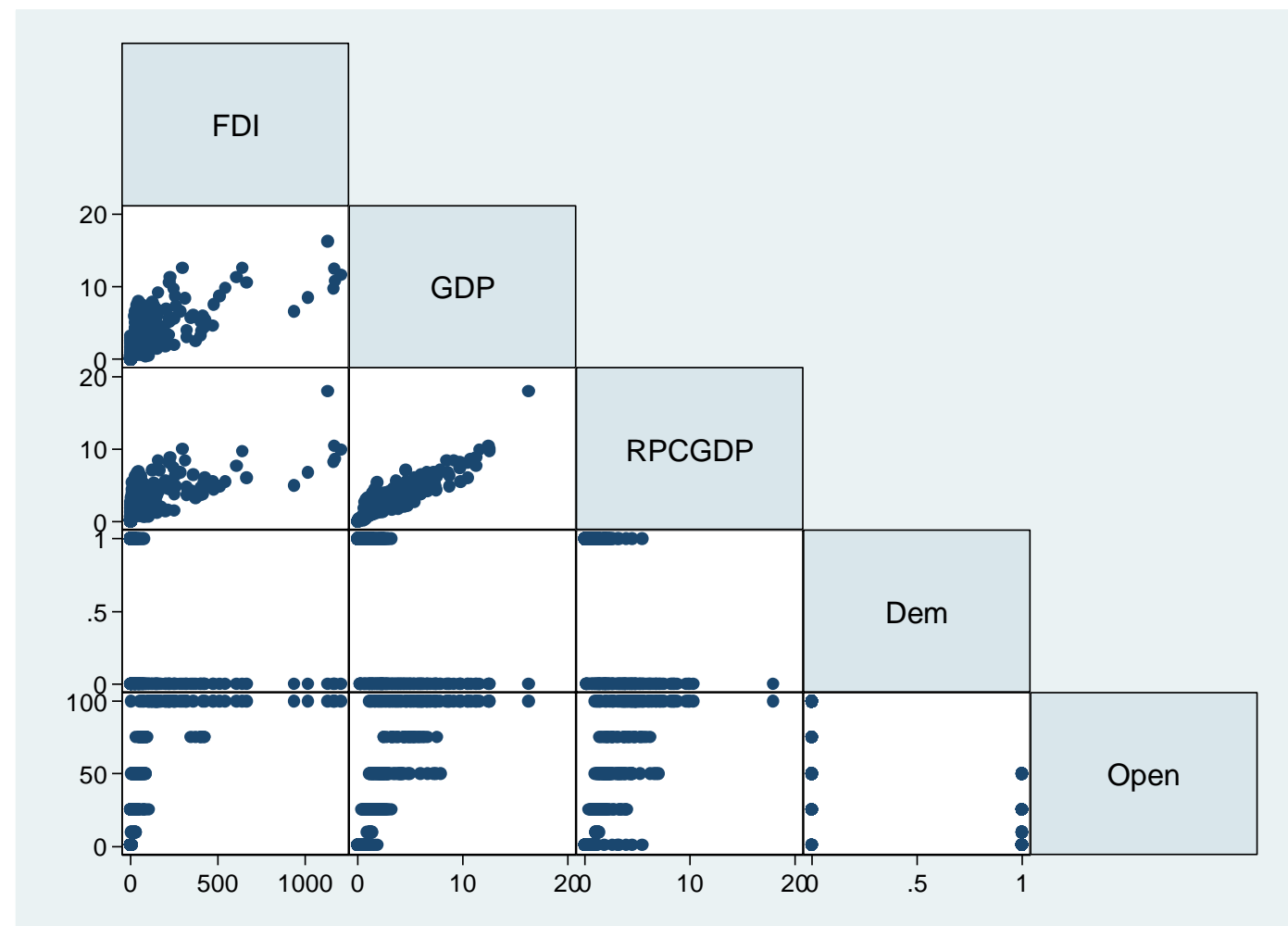

We can note that there are some issues with the individual graphs of FDI and our independent variables, so we need to take a closer look at necessary steps to fix our dataset. Looking at both FDI and GDP, and FDI and RPCGDP, we can see several 
outliers that can make our overall analyses ineffective, so we will need to test our regression to ensure that we have normal distribution, linearity, homoscedasticity, and non-multicollinearity. We used the kernel density estimate to see how our variables perform in hopes to have a normal distribution. Graph 2 provides the illustration.

Graph 2: Kernel Density Estimate of Residuals for Model 1

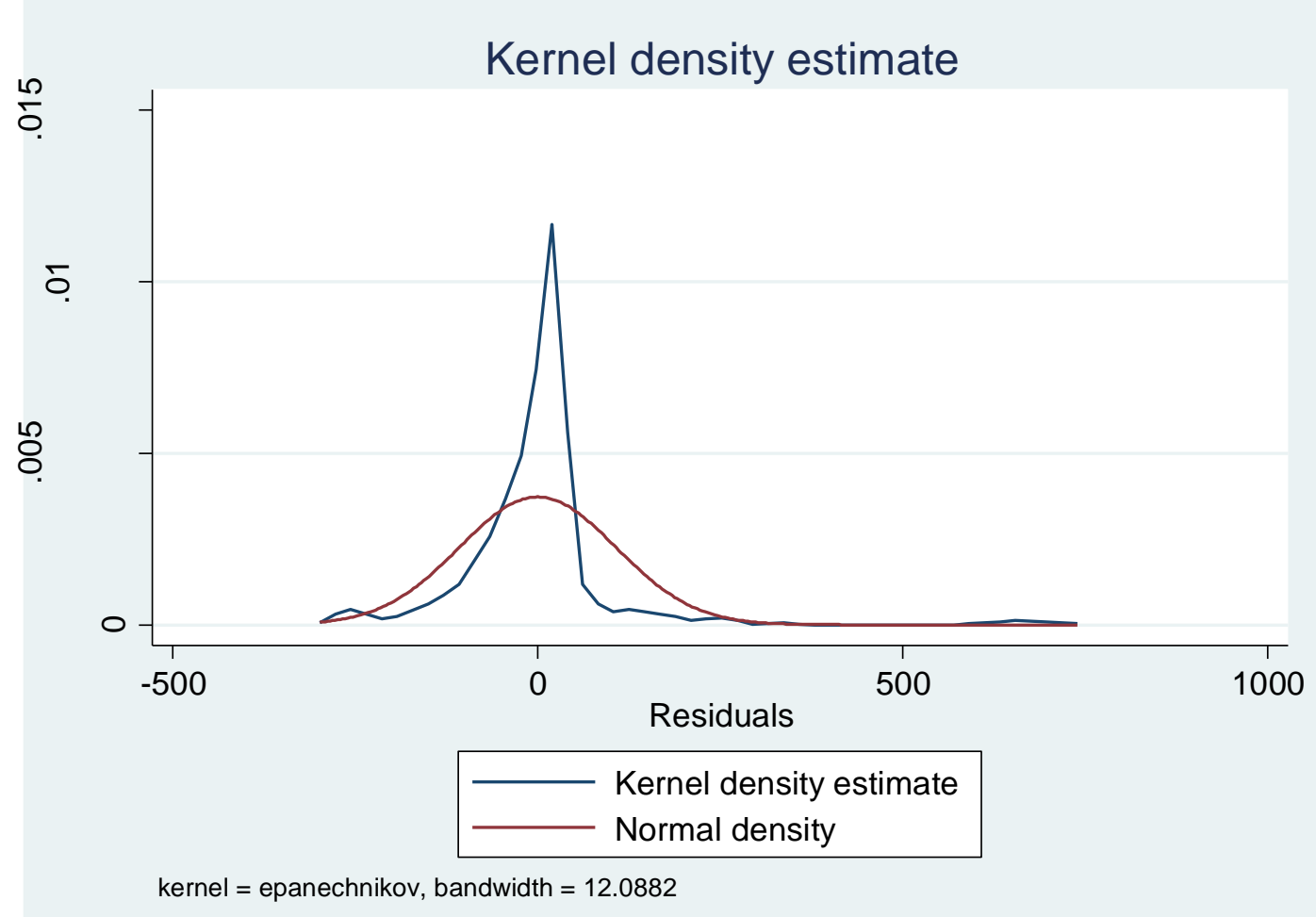

The graph does have minor issues, but we can move forward in our analyses and check for linearity. 
Graph 3: Kernel Density Estimate of GDP for Model 1

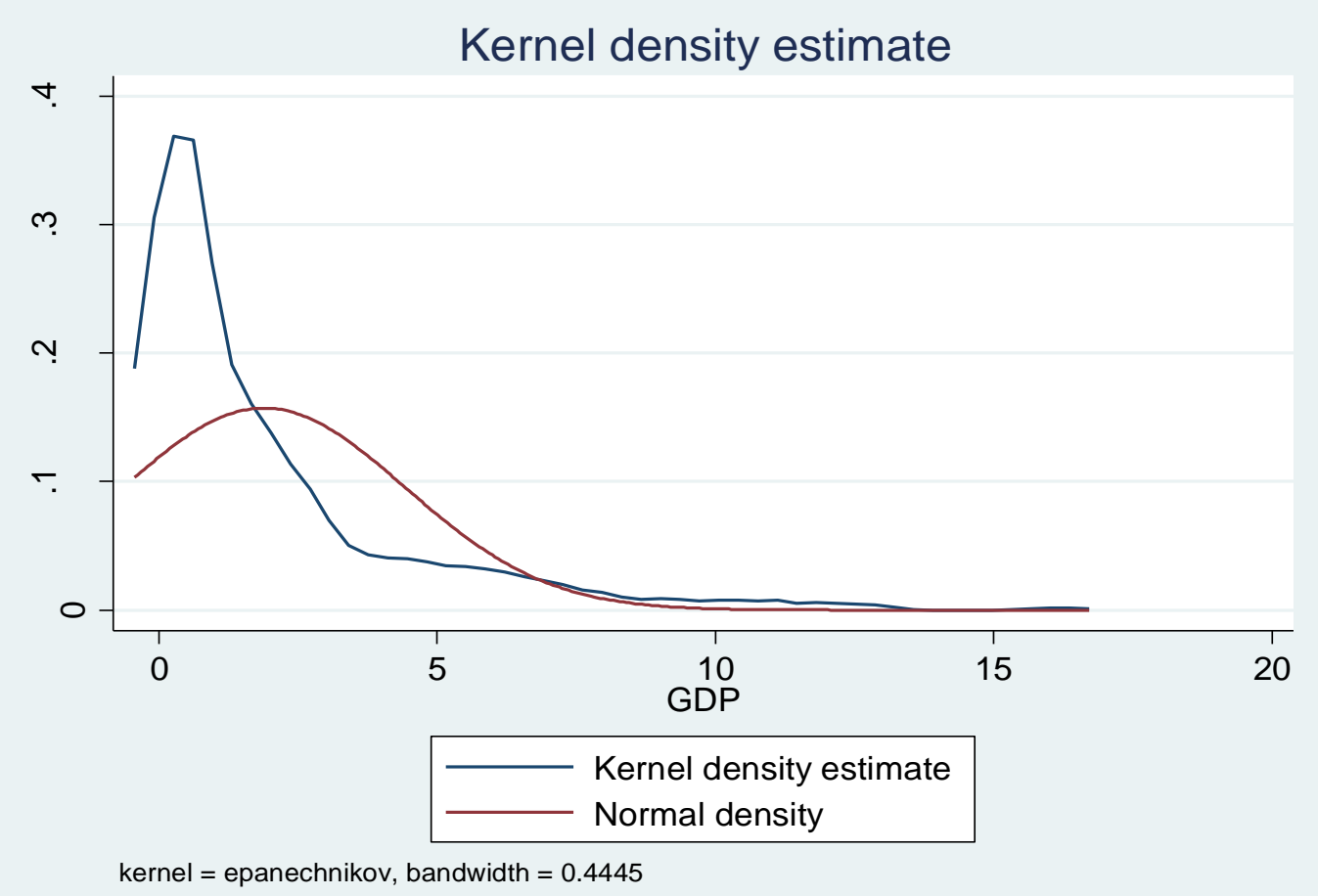

Graph 4: Kernel Density Estimate of RPCGDP for Model 1

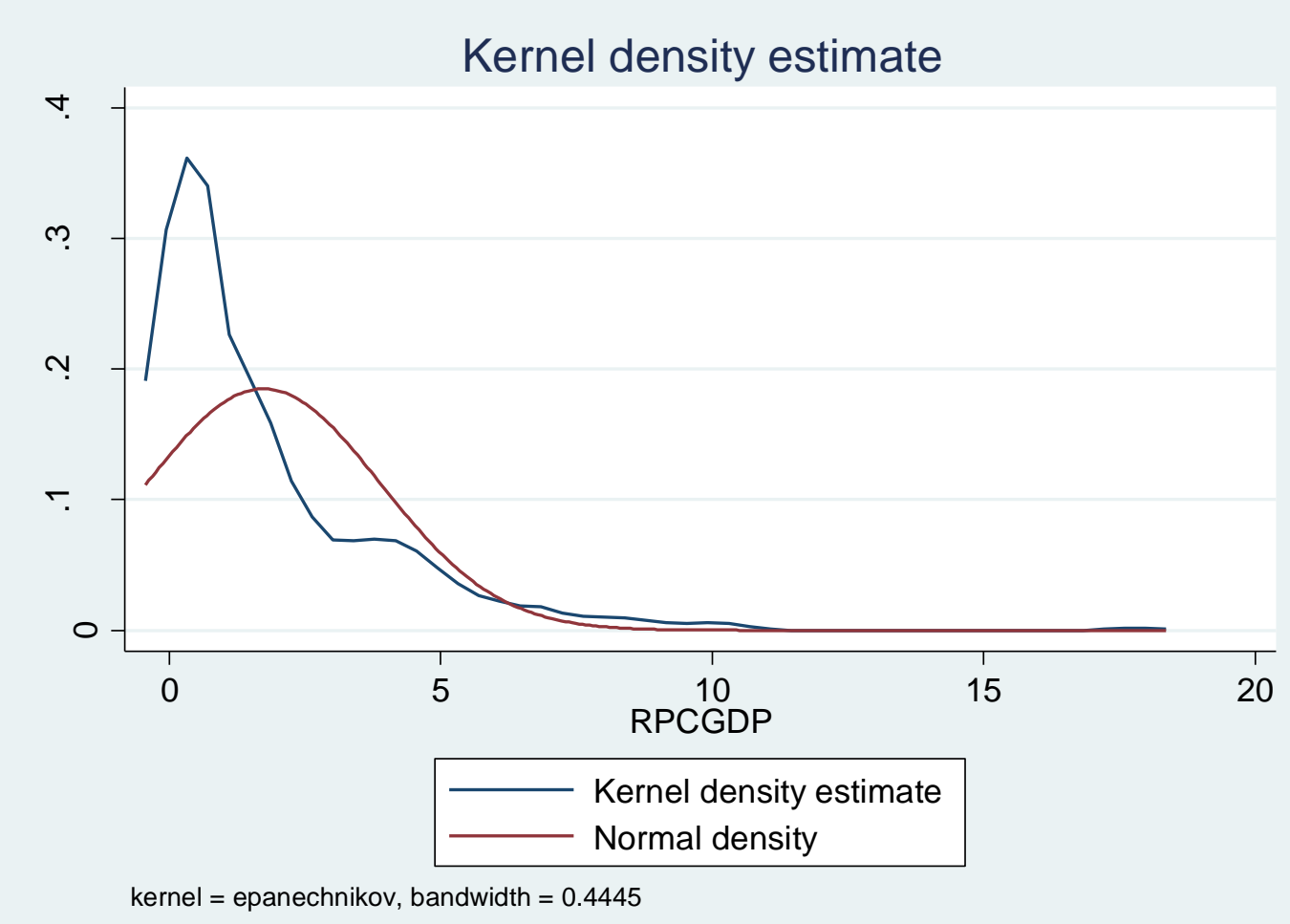


It is important to ensure that our regression analysis is linear as it will assist provincial governments of developing countries to forecast future economic trends not to mention assessing the strength of the variables used for political decisions. We have used the augmented partial residual plot to determine how linear our dataset is to successfully predict future trends. Graphs 5, 6, and 7 provide the illustrations.

\section{Graph 5: ACPR Plot of GDP for Model 1}

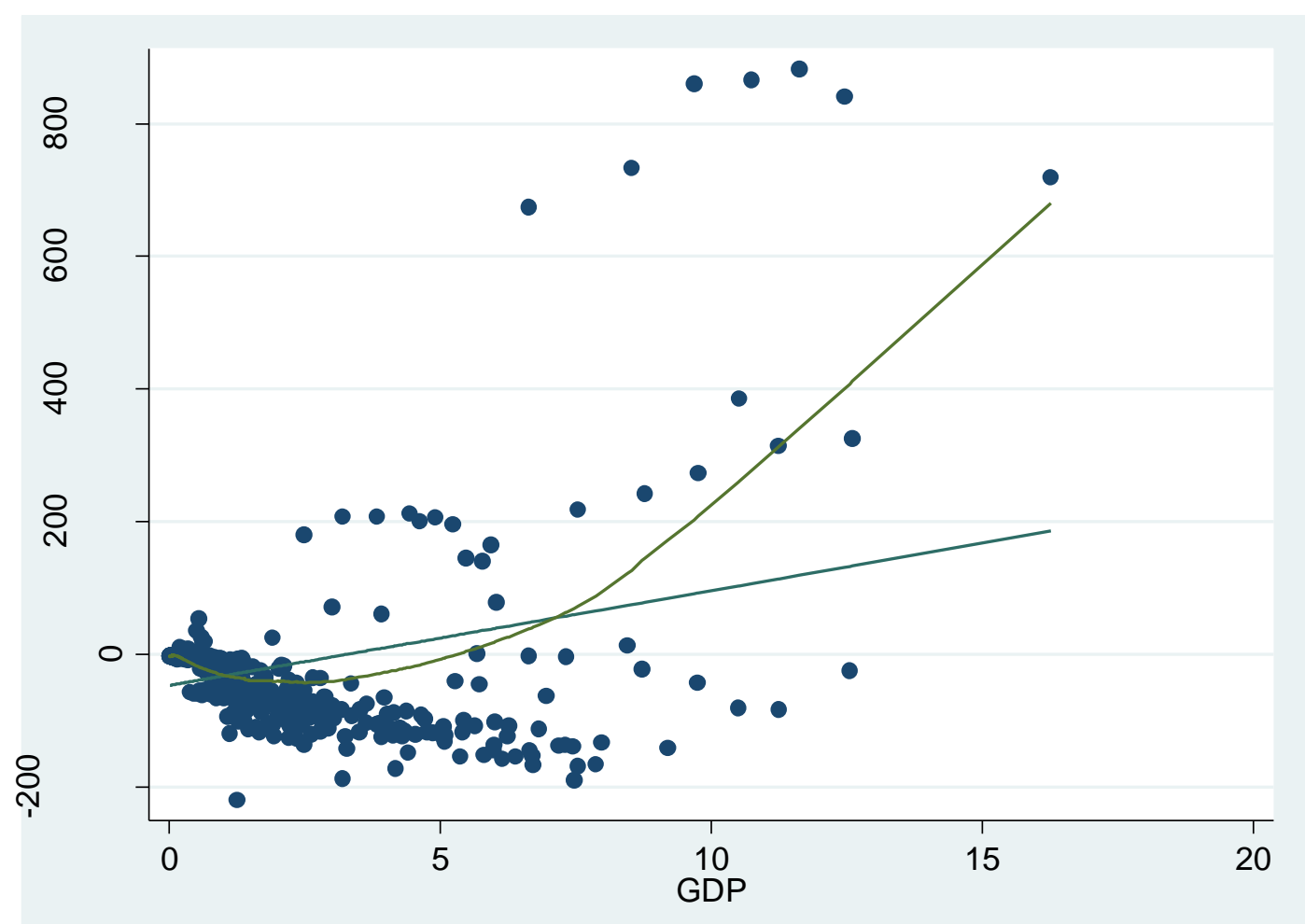

This graph does start out fairly well until we see GDP increase over eight billion dollars, but this is expected considering GDP is income that can exponentially increase each year, especially for a country. We need to take note that there are a few outliers that is causing this graph to be non-linear, so we have taken the step to take the log of GDP in hopes of correcting the linearity issue. Graph 6 provides the illustration. 


\section{Graph 6: ACPR Plot of logGDP for Model 1}

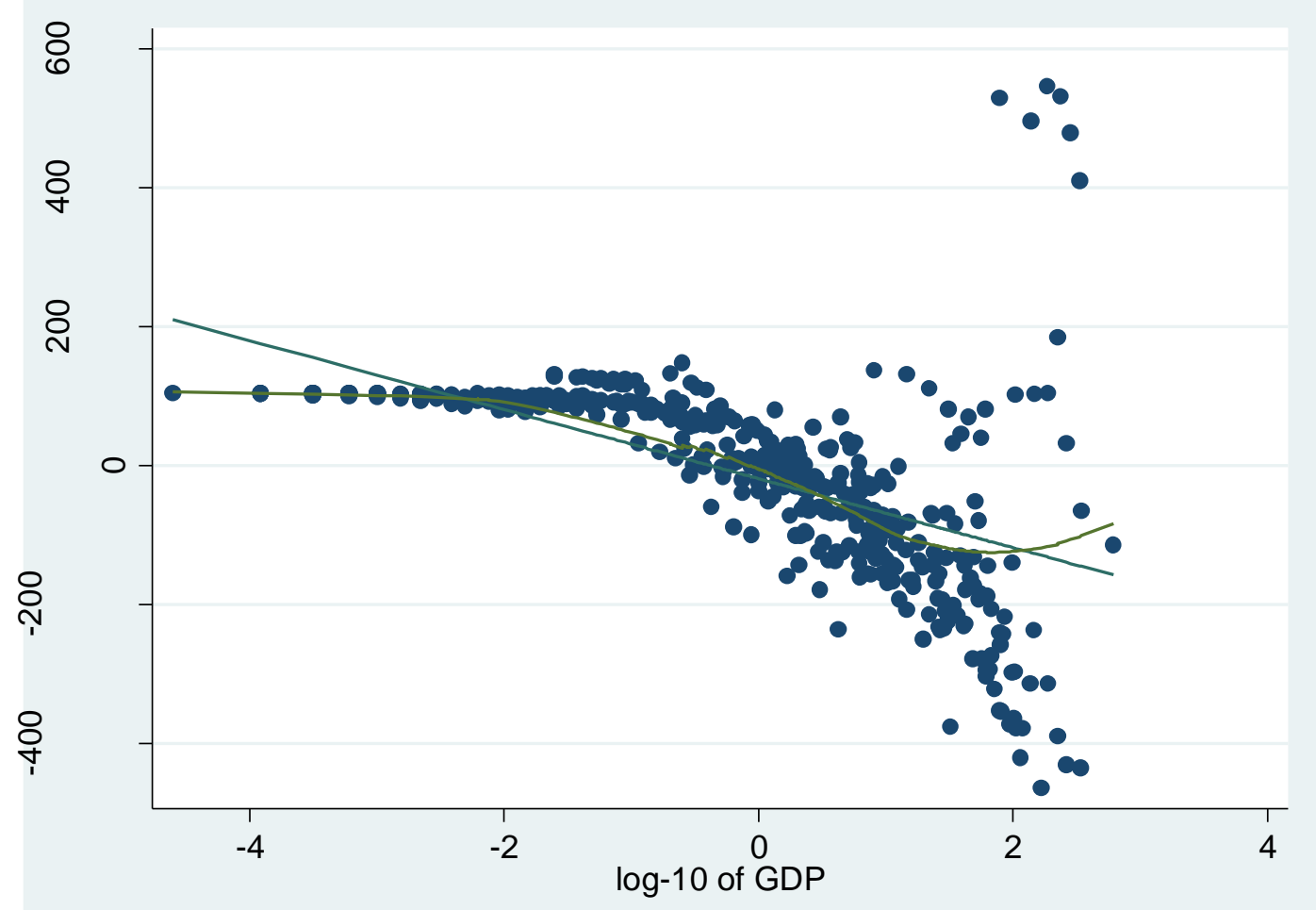

This graph does do a better job relative to graph 5 in terms of linearity. However, it is important to note that by taking the natural log of GDP into the model, it makes our interaction variable of RPCGDP statistically insignificant. One option to consider is to drop the variable GDP altogether as we would still achieve our desired results. Nevertheless, this is one issue we need to take note for future references as we may need to revisit our dataset to ensure that we do not have missing variables. 


\section{Graph 7: ACPR Plot of RPCGDP for Model 1}

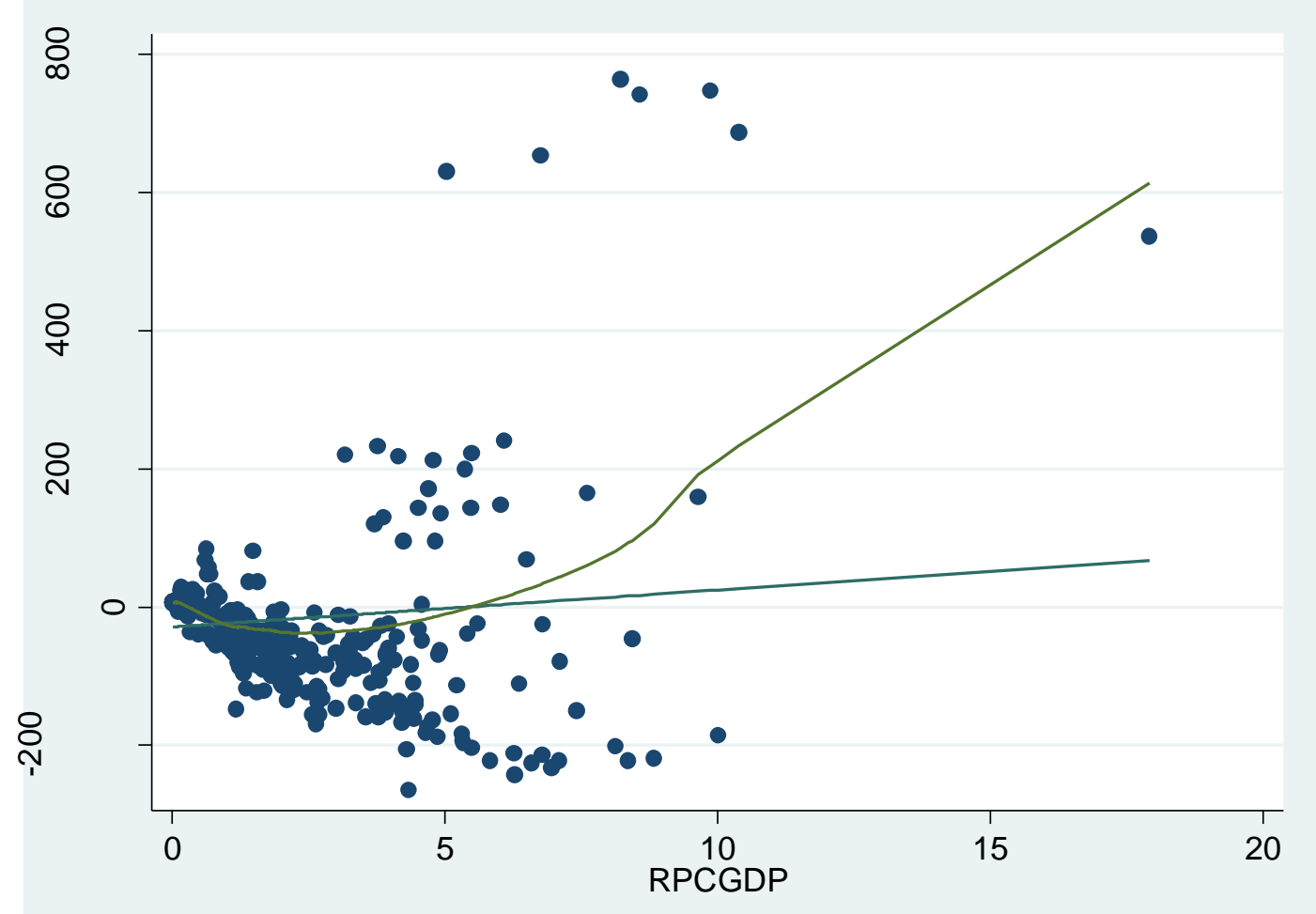

The same issue here arises as RPCGDP also exponentially increases after reaching six.

We have also taken the step to log our variable in hopes to find a more linear regression.

Graph 8 provides the illustration. Since RPCGDP is our main variable, we need to keep this in its proper form. 
Graph 8: ACPR Plot of logRPCGDP for Model 1

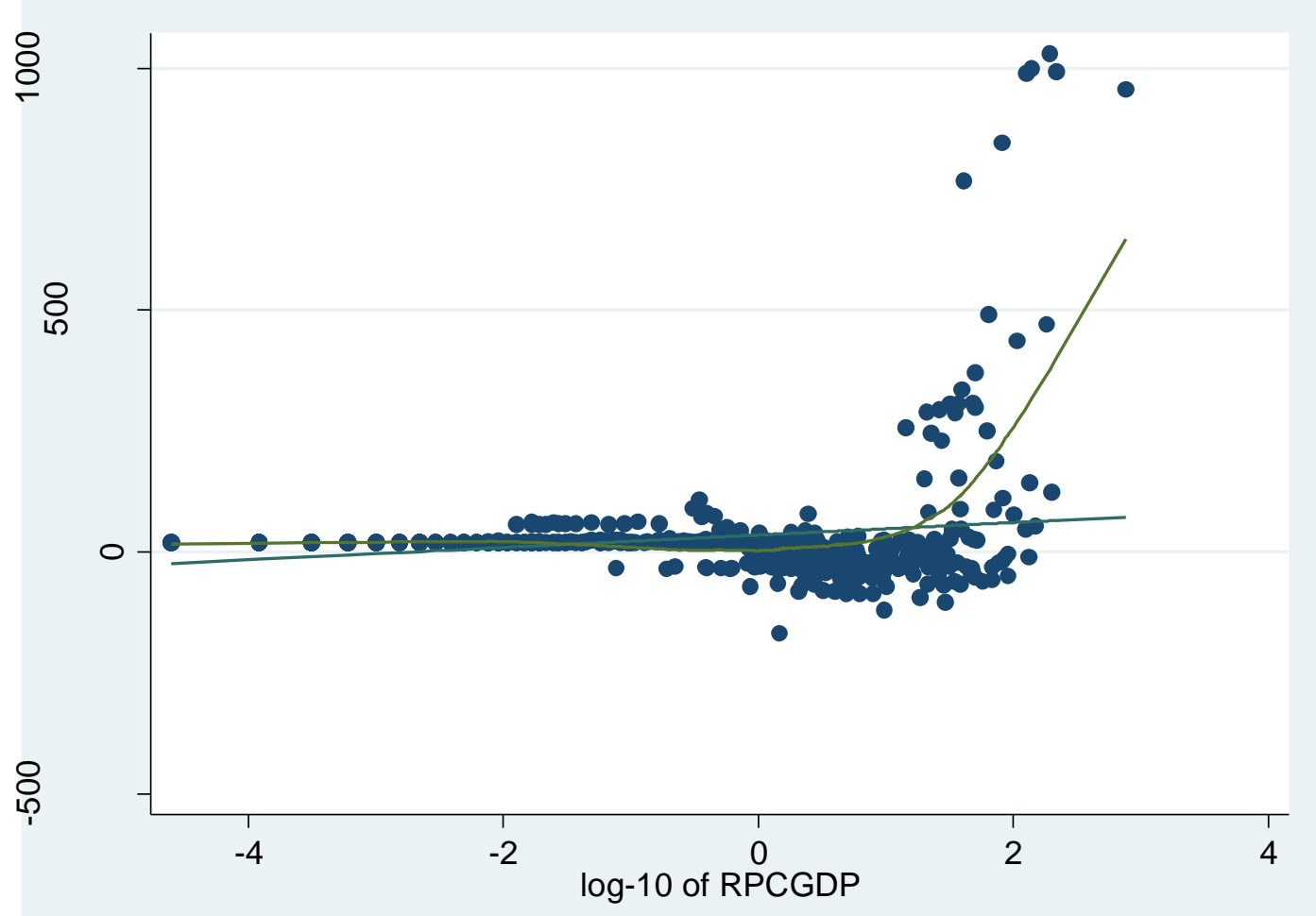

This graph also does a better job relative to the graph 7 , but like what was mentioned earlier, we cannot omit nor change our main variable in our model, so for the purpose of experimentation, this graph was included to determine the effectiveness of our interaction variable in natural log form, and indeed, it does provide a better linear picture than our original data. 


\section{Graph 9: ACPR Plot of Open Economy for Model 1}

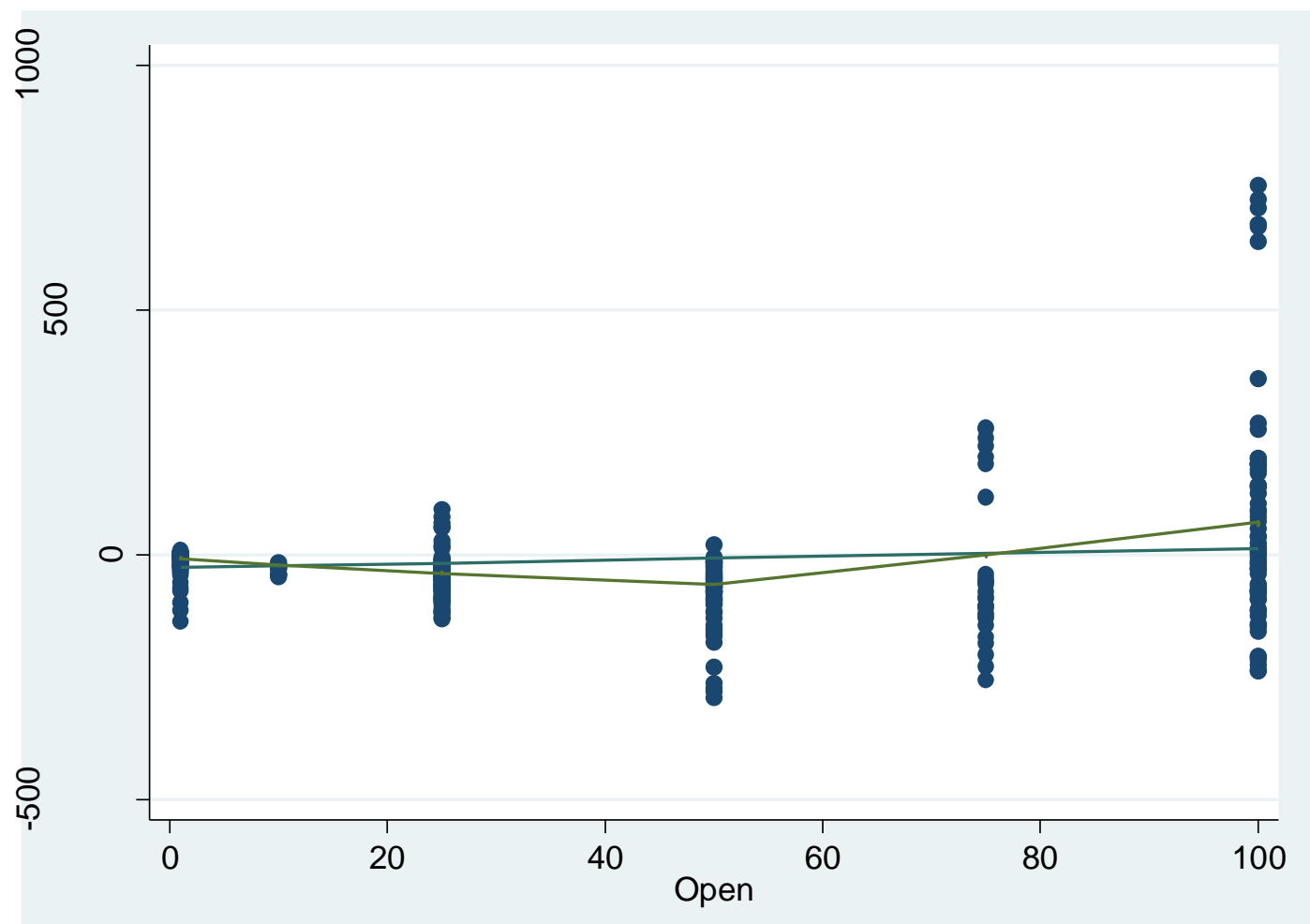

This graph does provide the linearity requirement needed to forecast future trends along with assessing the strength of an open economy to attract FDI. It is important to note that provincial governments in developing countries must be able to take the necessary steps in opening its economy, more likely in the realm of political decisions, such as policies of free trade. We do see this example in our dataset as all three developing countries chosen have opened up its economies through a range of free trade policies since the midtwentieth century. However, it is also important to note that each developing countries economic success rate varies relative to each other as each one faced different circumstances throughout its governing tenure.

The next step is to test for homoscedasticity as this will validate our statistical testing that our variances are uncorrelated. Graph 10 provides the illustration. 
Graph 10: Residuals vs. Fitted Values

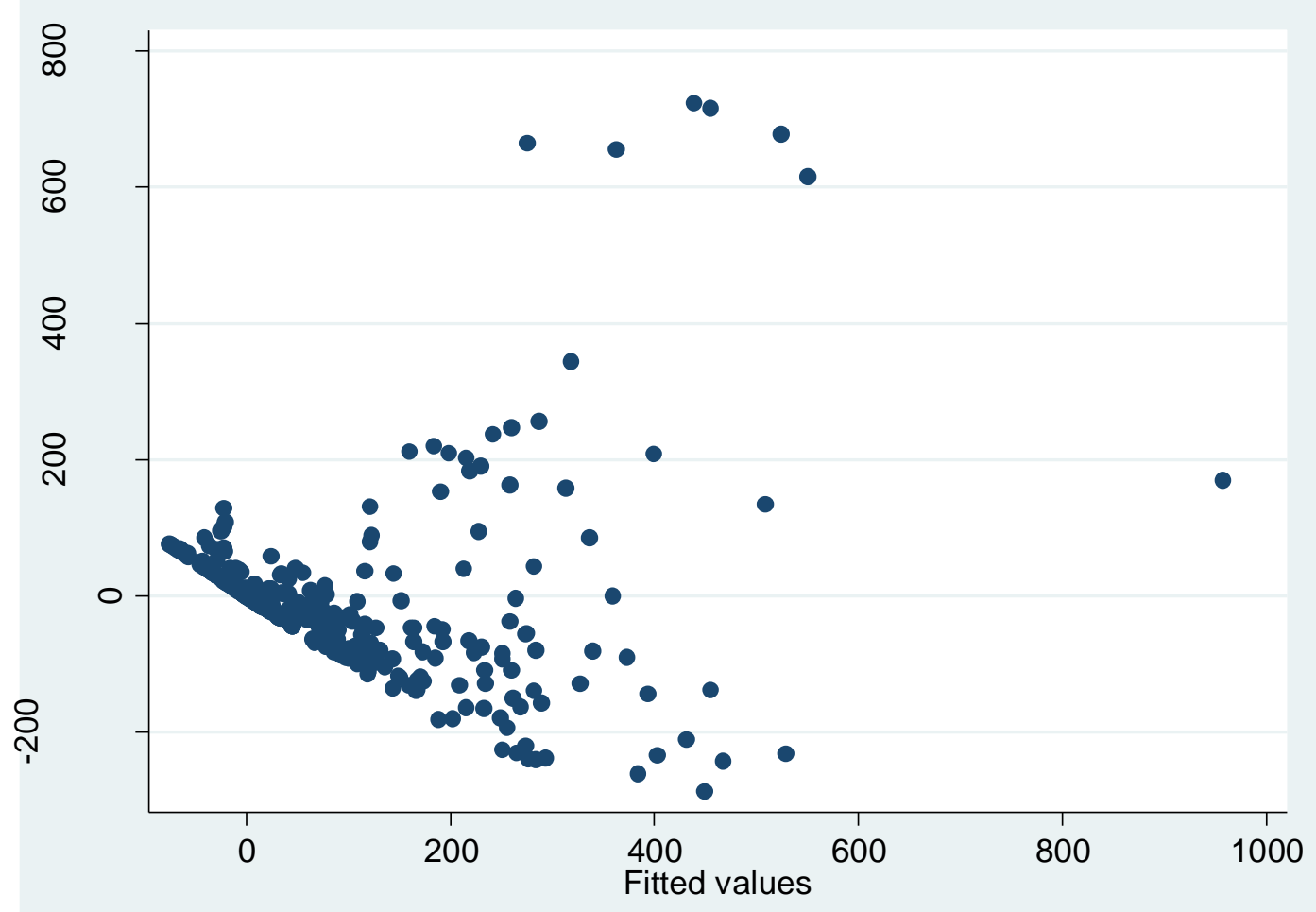

In addition, we also included a heteroscedasticity test called Breusch-Pagan and found our chi square to be extremely large and significant, which figure 9 indicates that we have heteroscedasticity in our analysis.

Figure 9: BP Test for Heteroscedasticity

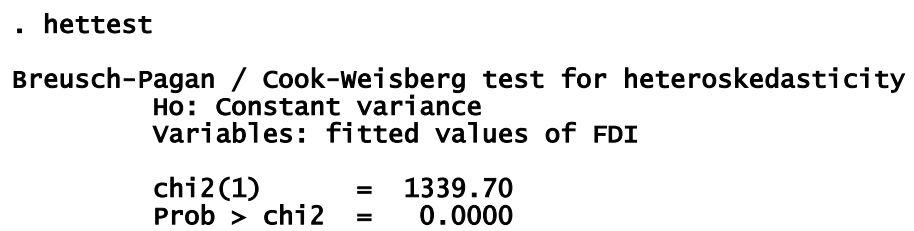

Hence, we ran our regression model with robust standard errors to fix this issue. Figure 10 illustrates the new regression analysis. 
Figure 10: Model 1 with Robust Standard Errors

\begin{tabular}{|c|c|c|c|c|c|c|}
\hline \multicolumn{5}{|c|}{ Linear regression } & \multirow{2}{*}{$\begin{array}{l}\text { Number of obs } \\
\text { F( 4, 485) } \\
\text { Prob }>\text { F } \\
\text { R-squared } \\
\text { Root MSE } \\
\text { [95\% conf. }\end{array}$} & \multirow{2}{*}{$\begin{array}{lr}= & 490 \\
= & 43.70 \\
= & 0.0000 \\
= & 0.5585 \\
= & 107.49 \\
& \\
& \end{array}$} \\
\hline FDI & coef. & $\begin{array}{l}\text { Robust } \\
\text { std. Err. }\end{array}$ & $t$ & $P>|t|$ & & \\
\hline $\begin{array}{r}\text { GDP } \\
\text { RPCGDP } \\
\text { Dem } \\
\text { Open } \\
\text { _cons }\end{array}$ & $\begin{array}{r}35.70257 \\
12.56402 \\
44.00503 \\
-5768624 \\
-71.52573\end{array}$ & $\begin{array}{l}10.37155 \\
10.06488 \\
11.29569 \\
.3920386 \\
13.72583\end{array}$ & $\begin{array}{r}3.44 \\
1.25 \\
3.90 \\
1.47 \\
-5.21\end{array}$ & $\begin{array}{l}0.001 \\
0.213 \\
0.000 \\
0.142 \\
0.000\end{array}$ & $\begin{array}{r}15.32385 \\
-7.212124 \\
21.8105 \\
-.1934415 \\
-98.49517\end{array}$ & $\begin{array}{r}56.08129 \\
32.34017 \\
66.19956 \\
1.347166 \\
-44.55628\end{array}$ \\
\hline
\end{tabular}

There seems to be an issue with our interaction variable as it is now considered insignificant. This forces us to be creative with our dataset, and see what happens when we omit one independent variable, GDP. There is also the fear of multicollinearity, so it would make sense to drop the GDP variable to ensure that our analysis is indeed valid. Figure 11 provides the illustration.

Figure 11: Model 1 without GDP

\begin{tabular}{|c|c|c|c|c|c|c|}
\hline \multicolumn{5}{|c|}{ Linear regression } & $\begin{array}{l}\text { Number of obs } \\
\mathrm{F}(3,486) \\
\text { Prob }>\mathrm{F} \\
\text { R-squared } \\
\text { Root MSE }\end{array}$ & $\begin{array}{lr}= & 490 \\
= & 51.91 \\
= & 0.0000 \\
= & 0.5315 \\
= & 110.62\end{array}$ \\
\hline FDI & coef. & $\begin{array}{l}\text { Robust } \\
\text { std. Err. }\end{array}$ & $t$ & $P>|t|$ & [95\% Conf. & Interva1] \\
\hline $\begin{array}{r}\text { RPCGDP } \\
\text { Dem } \\
\text { Open } \\
\text { cons }\end{array}$ & $\begin{array}{r}45.45263 \\
53.07678 \\
1.217187 \\
-85.41803\end{array}$ & $\begin{array}{l}9.295288 \\
13.09901 \\
.3322728 \\
16.11135\end{array}$ & $\begin{array}{r}4.89 \\
4.05 \\
3.66 \\
-5.30\end{array}$ & $\begin{array}{l}0.000 \\
0.000 \\
0.000 \\
0.000\end{array}$ & $\begin{array}{r}27.18871 \\
27.33909 \\
-5643185 \\
-117.0745\end{array}$ & $\begin{array}{r}63.71654 \\
78.81447 \\
1.870056 \\
-53.76153\end{array}$ \\
\hline
\end{tabular}

We can clearly see a stronger relationship with our dependent and independent variables. Also, the result is statistically significant with higher levels than that of model 1 with GDP included. Further, we can see our interaction variable, RPCGDP as the strongest variable to attract FDI, so we can suggest that this model does provide validity. Lastly, we need to test for multicollinearity. 
It is also very important to ensure that our variables are independent of each other and does not cause correlation as we want to ensure accuracy throughout the regression process. We tested for multicollinearity by using the variance inflation factor and figure 12 provides the illustration. Since model 1 includes GDP and RPCGDP, we assumed that multicollinearity is present due to the close relation between these variables, so we omitted GDP for the purpose of ensuing our regression analysis is both valid and accurate.

Figure 12: Variance Inflation Inflator for Model 1

\begin{tabular}{r|rr}
\multicolumn{1}{l}{$\begin{array}{l}\text { vif } \\
\text { Variable }\end{array}$} & VIF & $1 /$ VIF \\
\hline Open & 3.65 & 0.274061 \\
RPCGDP & 2.67 & 0.375156 \\
Dem & 2.28 & 0.438679 \\
\hline Mean VIF & 2.86 &
\end{tabular}

We can suggest that we do not have multicollinearity present in our dataset as our variance inflation inflator is well under four. Our regression analysis is indeed stable. It seems that our initial model did provide important information regarding a provincial government's ability to effectively attract FDI. Moreover, our regression analysis suggests that the interaction variable is indeed sufficient in jumpstarting economic growth. This is perhaps the missing piece of the mystery as to why many provincial governments cannot compete with other provinces not to mention other emerging markets worldwide. There must be the commitment by the provincial government to implement economic and political policies for a more open domestic economy in order for foreign capital to flow in. We will now see how our model performs in each individual developing country. 
China has proved to be a powerful developing country since the mid-to-late twentieth century as it consistently experienced record growth rates well above the U.S. Further, it consists of over thirty provinces, which ranges dramatically from rural to metropolitan areas, thus making it a challenge to aggregate economical and political variables. Nevertheless, each province is unique with its own characteristics and traits that only contribute to the overall welfare of the nation.

We expect China to be consistent with the literature in this study as it is the main driving force in effectively attracting FDI. We see that consistency in the model as RPC is insignificant, but the interaction variable, $\mathrm{RPC}^{*} \mathrm{GDP}$ is positive and significant therefore we will omit RPC in Model 2. We find that a one percent change in China's RPC*GDP will lead to a twenty-four million dollar increase in FDI. We have an R-square of fifty percent, which is also a good indicator that our variables explain FDI.

Model 2: China

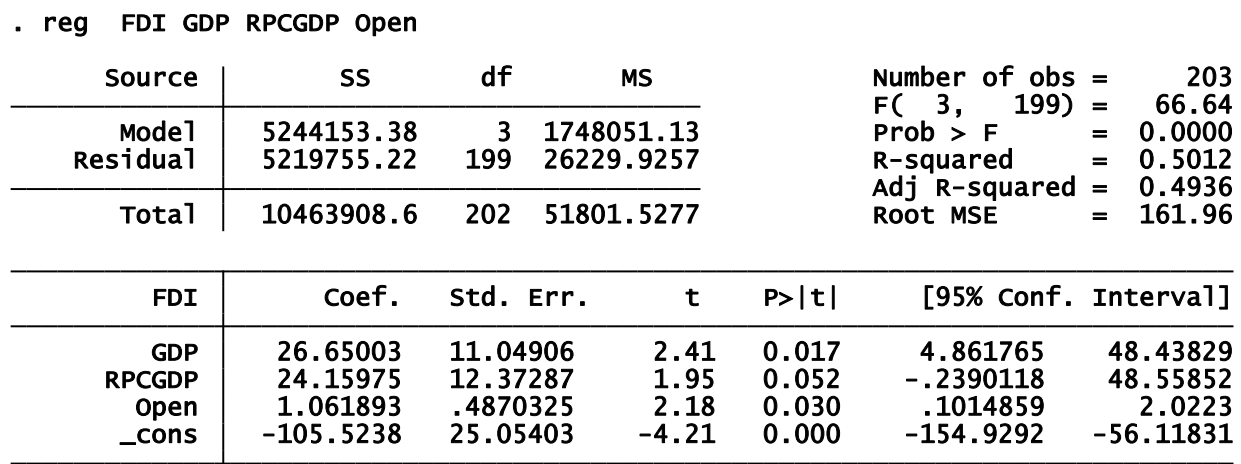

However, we need to take into account why RPC is insignificant as there is a vast difference between the rural west and the metropolitan east. When we compare two distinct provinces on opposite ends of the country, such as Qinghai and Shanghai, we see stark difference in their economies and politics. For example, our data collected for RPC gives Qinghai's level between 0 and 0.8, while Shanghai is between 1 and 1.3. This is an 
indicator that Shanghai's government is indeed capable in extracting resources from its people and transforming it to effective policies, thereby creating a positive environment for investors.

As for Qinghai, it is adjacent to Xinjiang and Xizang to the west both of which are autonomous regions. This creates a sense of instability among investors due to the uncertainty of public leaders, and for that matter a credible government governing those areas, which is perhaps an indicator of the low levels of RPC and FDI in Qinghai. Whereas Shanghai is located on the east coast adjacent to the Pacific Ocean, thereby allowing an easier route for trade and investment as multiple modes of transportation can easily go in and out of the province. Further, Shanghai is considered to be one of the largest international mega-ports in the world attracting well over twenty-five billion dollars of FDI each year.

Another factor that could potentially explain RPC's insignificance is that of incapable governments. Take the example of Jiangsu and Shanghai. Both provinces border each other in the east coast, but have different RPC and FDI levels. Unlike Shanghai, where its government is considered capable in extracting resources from its people, Jiangsu's RPC is between 0 and 0.8 similar levels to that of Qinghai. This can imply Jiangsu's government's inability to effectively extract resources from its people relative to Shanghai, regardless of geographical location. We could assume that both provinces should have the same RPC and FDI levels, but find both between 0 and 0.8 and 1 and 1.3, and an average of seven and twenty-five billion dollars each year, respectively. These factors are worth considering in Model 2, where the results imply RPC levels are insignificant. 
To extend on Model 2, we find that our variables, RPC*GDP, GDP, and Open Economy are indeed positive and significant, and is consistent with Model 1. Moreover, we expect to find GDP as a good indicator to gauge the country's overall growth as higher levels of GDP would imply a growing economy, hence a growing target market of consumers for investors to target. We find that a one percent change in China's GDP will lead to a twenty-six million dollar increase in FDI. We do see China today as the second largest economy behind the U.S, but more importantly, its GDP will eventually surpass that of the U.S in the next few decades as evidence by several indicators of growth, such as the rise of a middle class and capital invested abroad.

Lastly, we see the variable Open Economy consistent with the literature as our results suggest our coefficients to be positive and significant. We find that a one percent change in China's open economy will lead to a one million increase in FDI. Utilizing the Issue Continuum, we imply that open economies will attract investors to invest their capital as the most of the infrastructures are already provided, such as roads and highways, and technology. Plus, an open economy is a good indicator that the government promotes a free market capitalist environment, and not necessarily an iron fist of governance, although China itself is a good basket case for the previous statement.

Now, we can check for the four rules of regression analysis, and hope that we have not violated any of the assumptions. First, we need to ensure that our variables can be assessed in a uniform and consistent manner, so we need to run the model with beta coefficients and determine how strong of an indicator our main variable is. Figure 13 provides the illustration. 
Figure 13: Model 2 with Beta Coefficients

- reg FDI GDP RPCGDP open, b

\begin{tabular}{r|crc} 
Source & SS & df & MS \\
\hline $\begin{array}{r}\text { Mode1 } \\
\text { Residual }\end{array}$ & 5244153.38 & 3 & 1748051.13 \\
\hline Total & 10463908.6 & 202 & 51801.5277
\end{tabular}

Number of obs $=203$

$\mathrm{F}(3,199)=66.64$

Prob $>F=0.0000$

R-squared $=0.5012$

$\begin{array}{rll}\text { Adj R-squared } & =0.4936 \\ \text { Root MSE } & =161.96\end{array}$

\begin{tabular}{r|rlccr}
\hline FDI & Coef. & Std. Err. & $t$ & P $>|t|$ & Beta \\
\hline GDP & 26.65003 & 11.04906 & 2.41 & 0.017 & .3480849 \\
RPCGDP & 24.15975 & 12.37287 & 1.95 & 0.052 & .2593623 \\
Open & 1.061893 & .4870325 & 2.18 & 0.030 & .1519639 \\
_Cons & -105.5238 & 25.05403 & -4.21 & 0.000 &. \\
\hline
\end{tabular}

We do see our interaction variable with roughly twenty-six percent indicating that it does have a strong weight in terms of our dependent variable. With no surprise, GDP also has a stronger weight on FDI, which is expected for our model. Next, we need to check to see if our model is normally distributed.

\section{Graph 11: Correlation Matrix of Model 2}

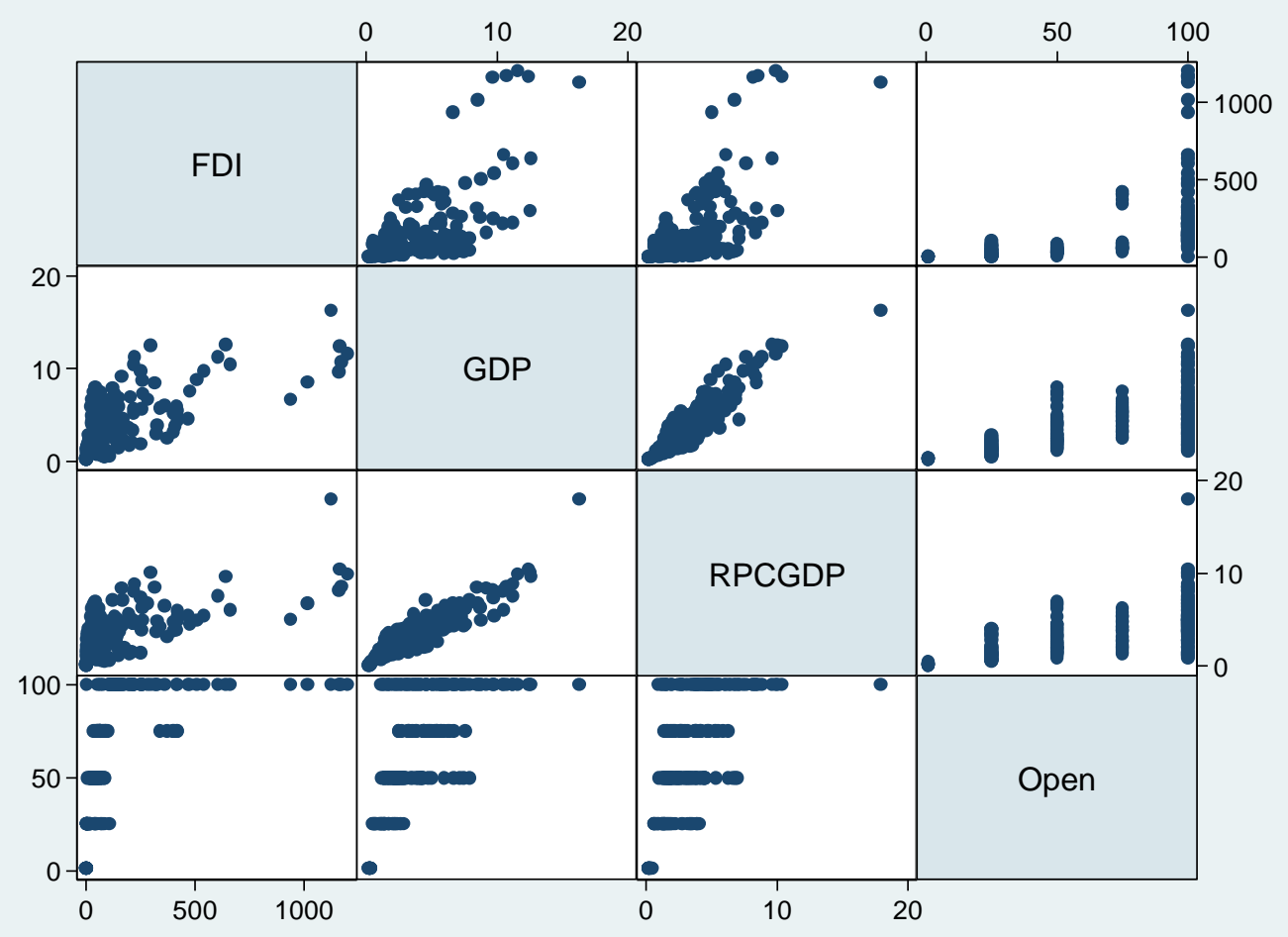


Automatically, we see a few issues with our observations, primarily that of outliers, so we will need to investigate each of our variables in depth to ensure that our analysis is valid. We will implement the Kernel density estimate to determine if our residuals are normally distributed. Graph 11 provides the illustration.

Graph 12: Kernel Density Estimate of Residuals for Model 2

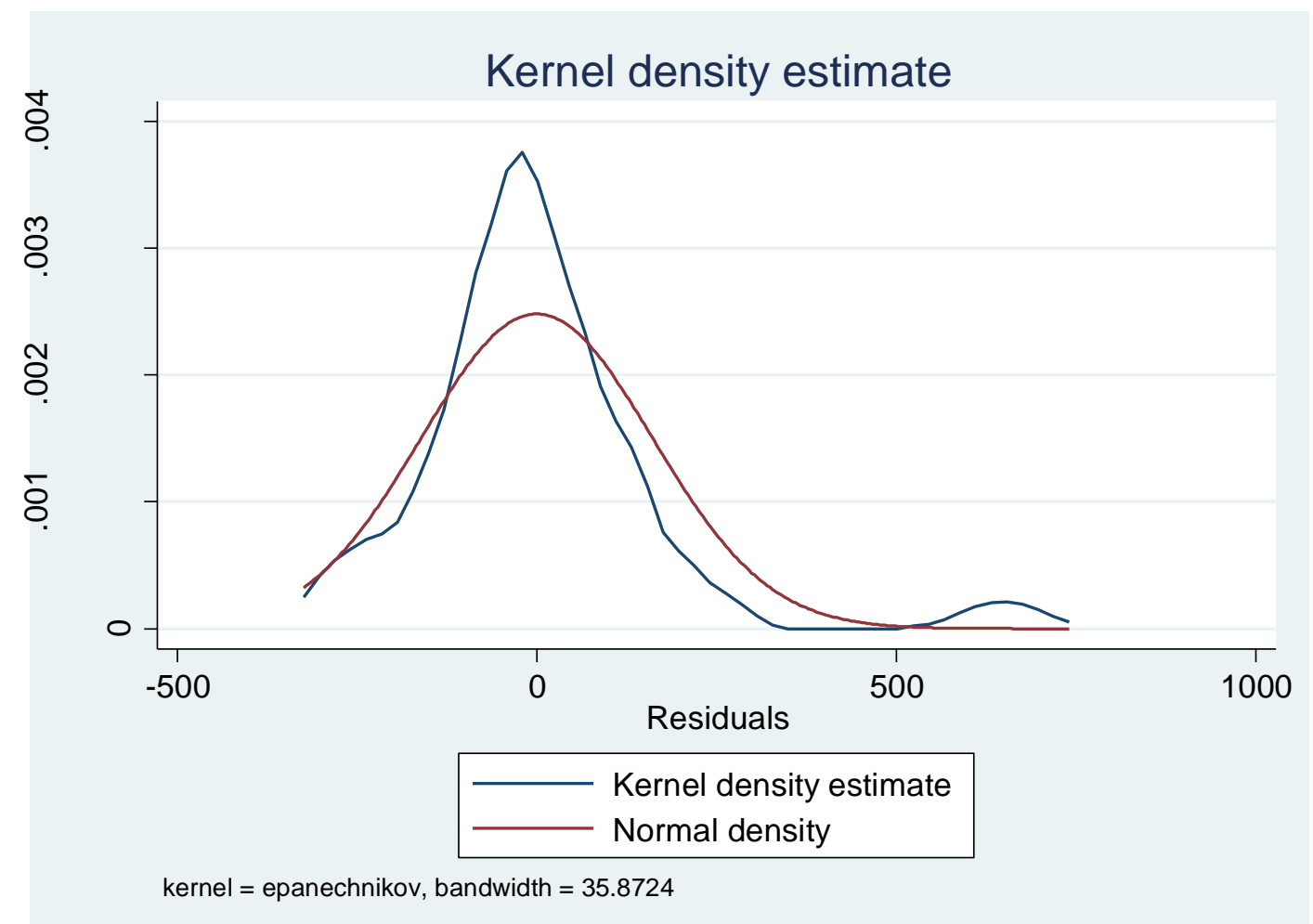

The graph does depict our residuals to be normally distributed as expected, so we can move on to the next test. We need to ensure that our regression analysis does provide a linear relationship for forecasting efforts, so we will implement the augmented partial residual plot for each independent variable. Graphs 12 and 13 provide the illustration. 
Graph 13: ACPR of GDP for Model 2

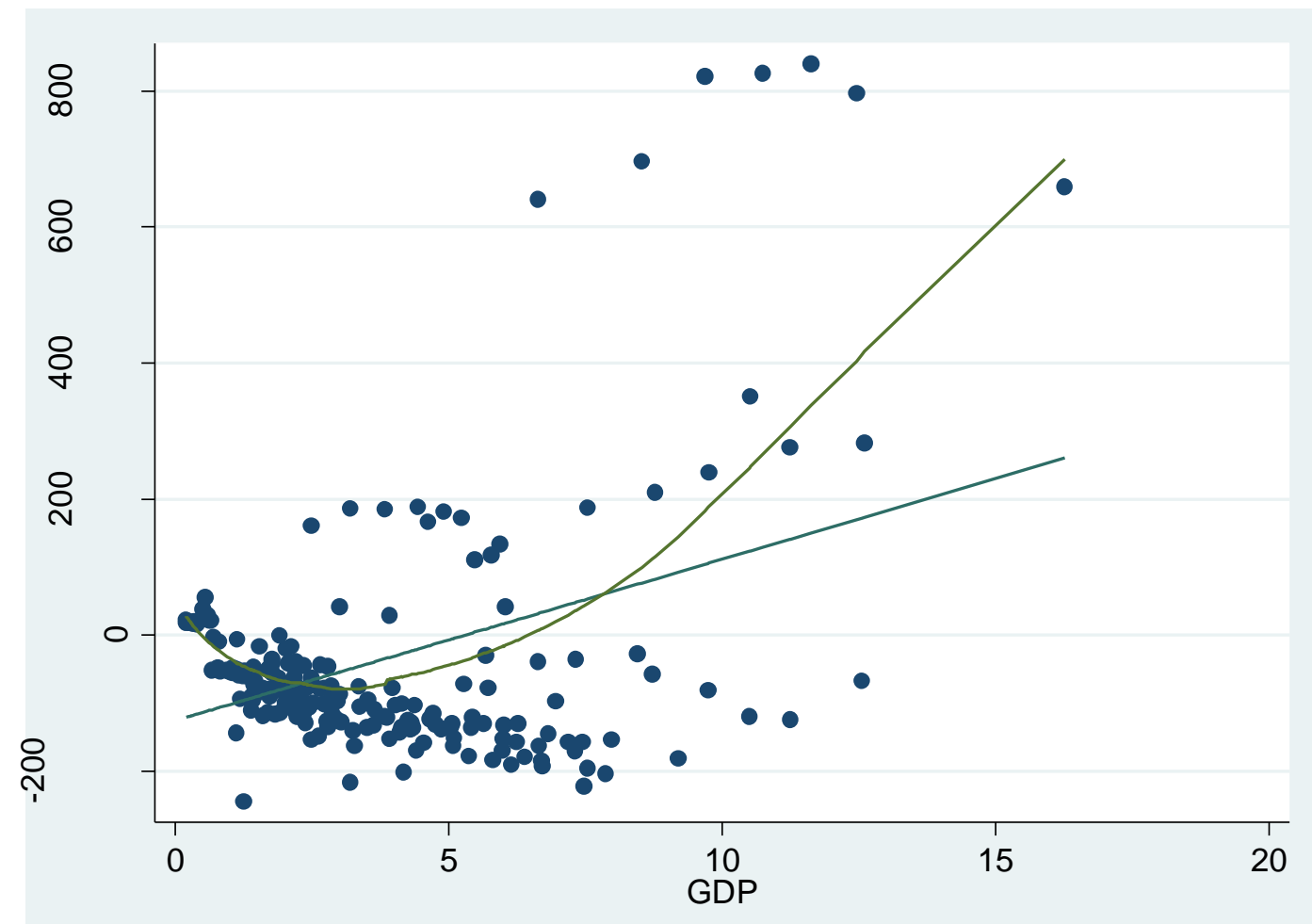

Similar to model 1 , we do see a minor issue with our linearity in that after eight billion dollars, the observation exponentially increases. Again, due to the nature of the income variable, this is expected to occur, so one solution to this is to take the natural log of GDP then plot it, or to omit GDP altogether. 
Graph 14: ACPR of RPCGDP for Model 2

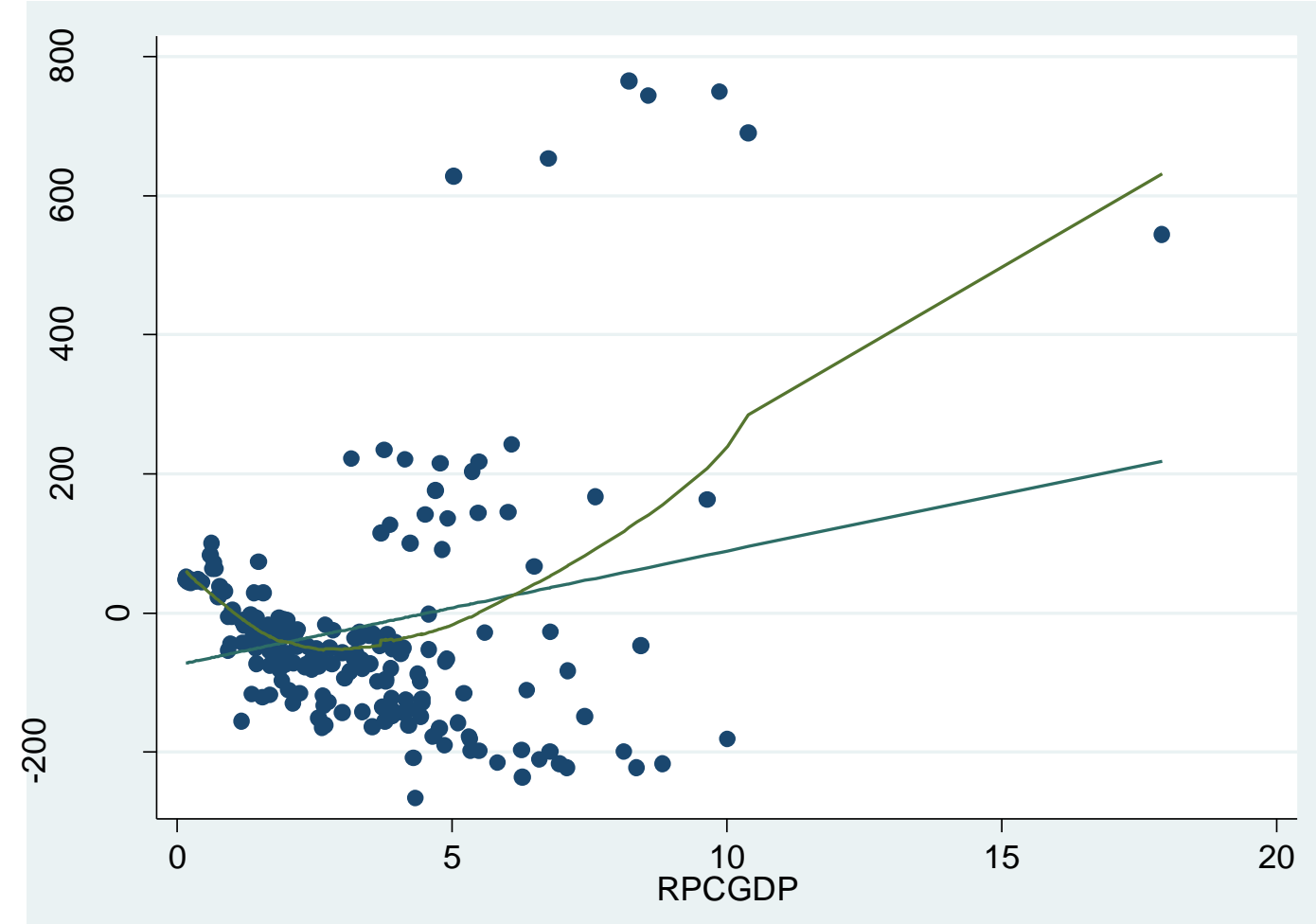

The linearity issue is also prevalent as was in the previous graph, and we also see a consistent pattern in model 1 when all three countries are regressed. However, since RPCGDP is our main variable, we will need to move on, but keep this in mind for future references. Our next test is for heteroscedasticity. We will plot our residuals relative to our predicted values and hope to see constant variation. Graph 14 provides the illustration. 
Graph 15: Residuals vs. Fitted Values

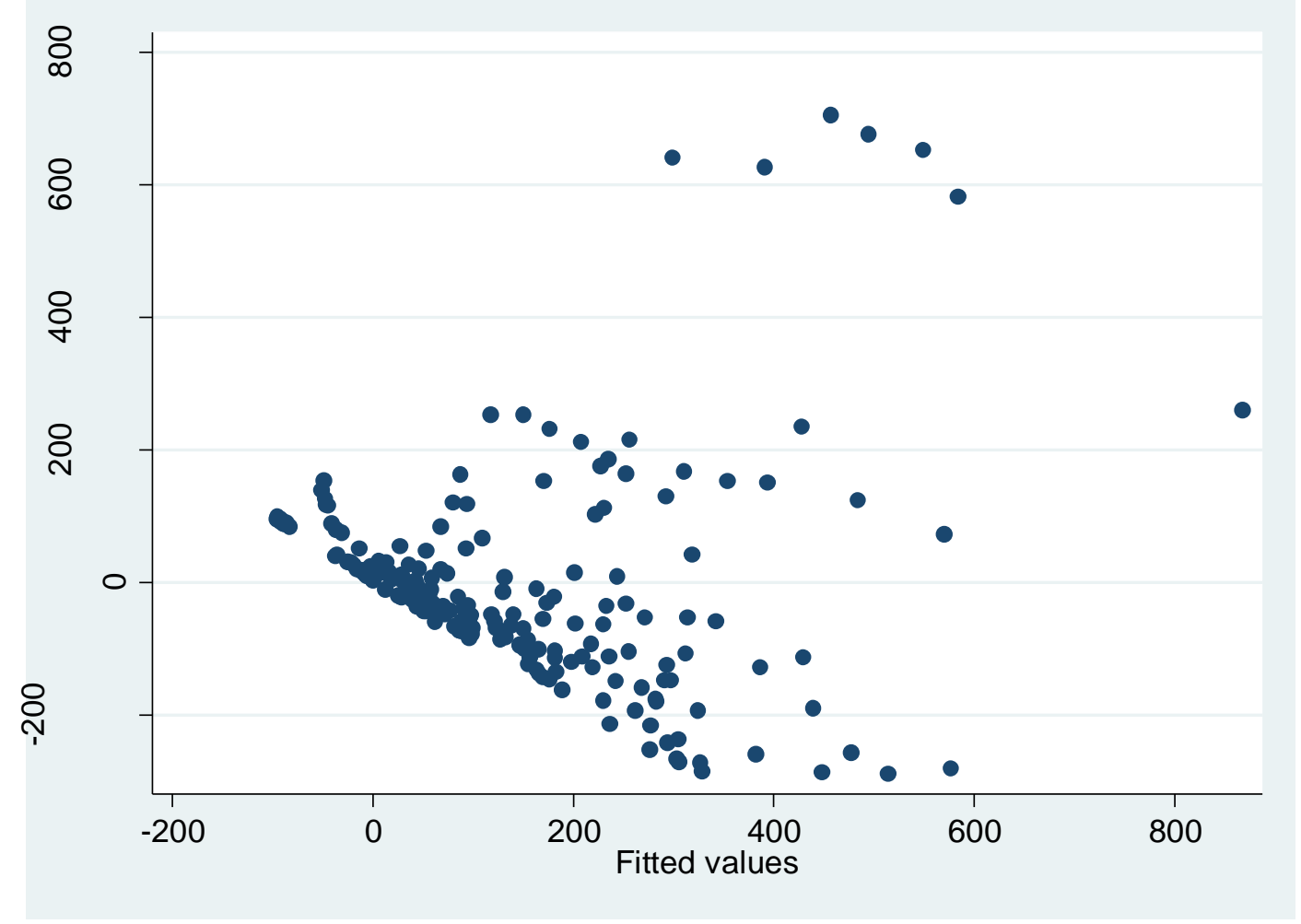

There is definitely a sign of heteroscedasticity in our graph as most of the observations are clumped together at the zero level of both $\mathrm{x}$ and $\mathrm{y}$ axes. We will take a look at the Breusch-Pagan test to ensure our assumption. Figure 14 provides the results.

Figure 14: BP Test for Heteroscedasticity

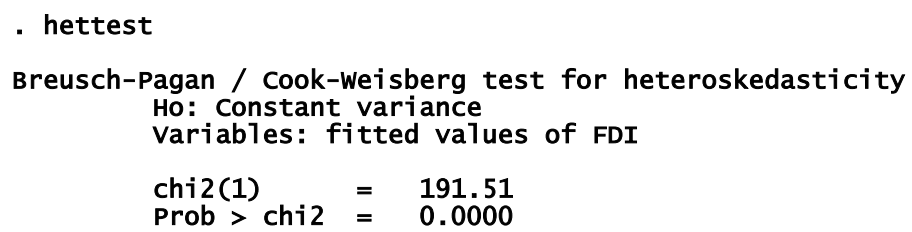

The Breush-Pagan test does validate that our model is heteroscedastic, hence we need to rerun the model with robust standard errors. 
Figure 15: Model 2 with Robust Standard Errors

\begin{tabular}{|c|c|c|c|c|c|c|}
\hline \multicolumn{5}{|c|}{ Linear regression } & $\begin{array}{l}\text { Number of obs } \\
\mathrm{F}(3,199) \\
\text { Prob }>\mathrm{F} \\
\text { R-squared } \\
\text { Root MSE }\end{array}$ & $\begin{array}{lr}= & 203 \\
= & 37.07 \\
= & 0.0000 \\
= & 0.5012 \\
= & 161.96\end{array}$ \\
\hline FDI & coef. & $\begin{array}{l}\text { Robust } \\
\text { std. Err. }\end{array}$ & $t$ & $P>|t|$ & [95\% conf. & Interva1] \\
\hline $\begin{array}{r}\text { GDP } \\
\text { RPCGDP } \\
\text { Open } \\
\text { _cons }\end{array}$ & $\begin{array}{r}26.65003 \\
24.15975 \\
1.061893 \\
-105.5238\end{array}$ & $\begin{array}{l}11.29514 \\
12.06942 \\
.4256557 \\
17.79594\end{array}$ & $\begin{array}{r}2.36 \\
2.00 \\
2.49 \\
-5.93\end{array}$ & $\begin{array}{l}0.019 \\
0.047 \\
0.013 \\
0.000\end{array}$ & $\begin{array}{r}4.376494 \\
.3593812 \\
.2225182 \\
-140.6166\end{array}$ & $\begin{array}{r}48.92356 \\
47.96013 \\
1.901268 \\
-70.43094\end{array}$ \\
\hline
\end{tabular}

We need to note that our variables continue to be statistically significant. Finally, we can check for multicollinearity. We will run the variance inflation inflator to determine whether our model has multicollinearity. Figure 16 provides the results.

Figure 16: Variance Inflation Inflator for Model 2

\begin{tabular}{|c|c|c|}
\hline Variable & VIF & 1/VIF \\
\hline $\begin{array}{r}\text { GDP } \\
\text { RPCGDP } \\
\text { Open }\end{array}$ & $\begin{array}{l}8.31 \\
7.04 \\
1.94\end{array}$ & $\begin{array}{l}0.120359 \\
0.142080 \\
0.516022\end{array}$ \\
\hline Mean VIF & 5.76 & \\
\hline
\end{tabular}

Similar to model 1, we did expect both variables GDP and RPCGDP to be highly correlated, which is why we have large variance inflation inflator numbers at eight and seven, respectively. The only solution to this issue is to rerun our model omitting GDP. And by doing so, we should be able to fix the multicollinearity issue. Once we omitted GDP from the model, we can see our variance inflation inflator improve as figure 17 provides the results.

Figure 17: Variance Inflation Inflator for Model 2 without GDP

\begin{tabular}{l|rr}
\multicolumn{1}{l}{ vif } \\
Variable & VIF & $1 /$ VIF \\
\hline Open & 1.63 & 0.612347 \\
RPCGDP & 1.63 & 0.612347 \\
\hline Mean VIF & 1.63 &
\end{tabular}


We can now suggest that our model has taken care of the multicollinearity issue. In addition, by omitting the GDP variable, our model 2 has also improved in other avenues, namely, normal distribution and linearity. We will rerun model 2 along with its beta coefficients to provide the illustration in figure 18.

Figure 18: Model 2 without GDP

\begin{tabular}{|c|c|c|c|c|c|c|c|}
\hline Source & ss & $d f$ & \multicolumn{2}{|c|}{ MS } & & \multirow{3}{*}{$\begin{array}{l}\text { Number of obs } \\
\text { F( 2, 200) } \\
\text { Prob > F } \\
\text { R-squared } \\
\text { Adj R-squared } \\
\text { Root MSE }\end{array}$} & \multirow{3}{*}{$\begin{array}{rr}= & 203 \\
= & 94.77 \\
= & 0.0000 \\
= & 0.4866 \\
= & 0.4814 \\
= & 163.9\end{array}$} \\
\hline $\begin{array}{r}\text { Mode1 } \\
\text { Residua1 }\end{array}$ & $\begin{array}{l}5091557.84 \\
5372350.76\end{array}$ & 200 & $\begin{array}{l}254 \\
268\end{array}$ & 538 & & & \\
\hline Total & 10463908.6 & 202 & 518 & 5277 & & & \\
\hline FDI & Coef. & std. & Err. & $t$ & $P>|t|$ & [95\% Conf. & Interva1] \\
\hline $\begin{array}{r}\text { RPCGDP } \\
\text { Open } \\
\text { _cons }\end{array}$ & $\begin{array}{r}50.31244 \\
1.527802 \\
-120.5288\end{array}$ & $\begin{array}{r}6.03 \\
245 \\
24.5\end{array}$ & $\begin{array}{l}247 \\
441 \\
994\end{array}$ & $\begin{array}{r}8.34 \\
3.38 \\
-4.91\end{array}$ & $\begin{array}{l}0.000 \\
0.001 \\
0.000\end{array}$ & $\begin{array}{r}38.41945 \\
-6356352 \\
-168.9585\end{array}$ & $\begin{array}{r}62.20543 \\
2.419968 \\
-72.09917\end{array}$ \\
\hline
\end{tabular}

\begin{tabular}{|c|c|c|c|c|c|c|c|}
\hline Source & ss & $d f$ & \multicolumn{2}{|c|}{ MS } & & \multirow{3}{*}{$\begin{array}{l}\text { Number of obs } \\
\text { F( 2, 200) } \\
\text { Prob > F } \\
\text { R-squared } \\
\text { Adj R-squared } \\
\text { Root MSE }\end{array}$} & \multirow{3}{*}{$\begin{array}{l}= \\
= \\
= \\
=\end{array}$} \\
\hline $\begin{array}{r}\text { Mode1 } \\
\text { Residual }\end{array}$ & $\begin{array}{l}5091557.84 \\
5372350.76\end{array}$ & $\begin{array}{r}2 \\
200\end{array}$ & $\begin{array}{l}2545 \\
2686\end{array}$ & $\begin{array}{l}78.92 \\
.7538\end{array}$ & & & \\
\hline Total & 10463908.6 & 202 & $518 \mathrm{C}$ & .5277 & & & \\
\hline FDI & Coef. & std. & Err. & $t$ & $P>|t|$ & & Beta \\
\hline $\begin{array}{r}\text { RPCGDP } \\
\text { Open } \\
\text { _cons }\end{array}$ & $\begin{array}{r}50.31244 \\
1.527802 \\
-120.5288\end{array}$ & $\begin{array}{r}6.031 \\
.452 \\
24.55\end{array}$ & $\begin{array}{l}247 \\
441 \\
994\end{array}$ & $\begin{array}{r}8.34 \\
3.38 \\
-4.91\end{array}$ & $\begin{array}{l}0.000 \\
0.001 \\
0.000\end{array}$ & & $\begin{array}{l}.5401194 \\
.2186385\end{array}$ \\
\hline
\end{tabular}

We do see an improvement from the initial model as our interaction variable is much more influential relative to FDI at fifty-four percent compared to nearly twenty-six percent. We also feel confident that our model does not violate the rules of normal distribution as graph 15 illustrates the relationship. 


\section{Graph 16: Pnorm of Model 2}

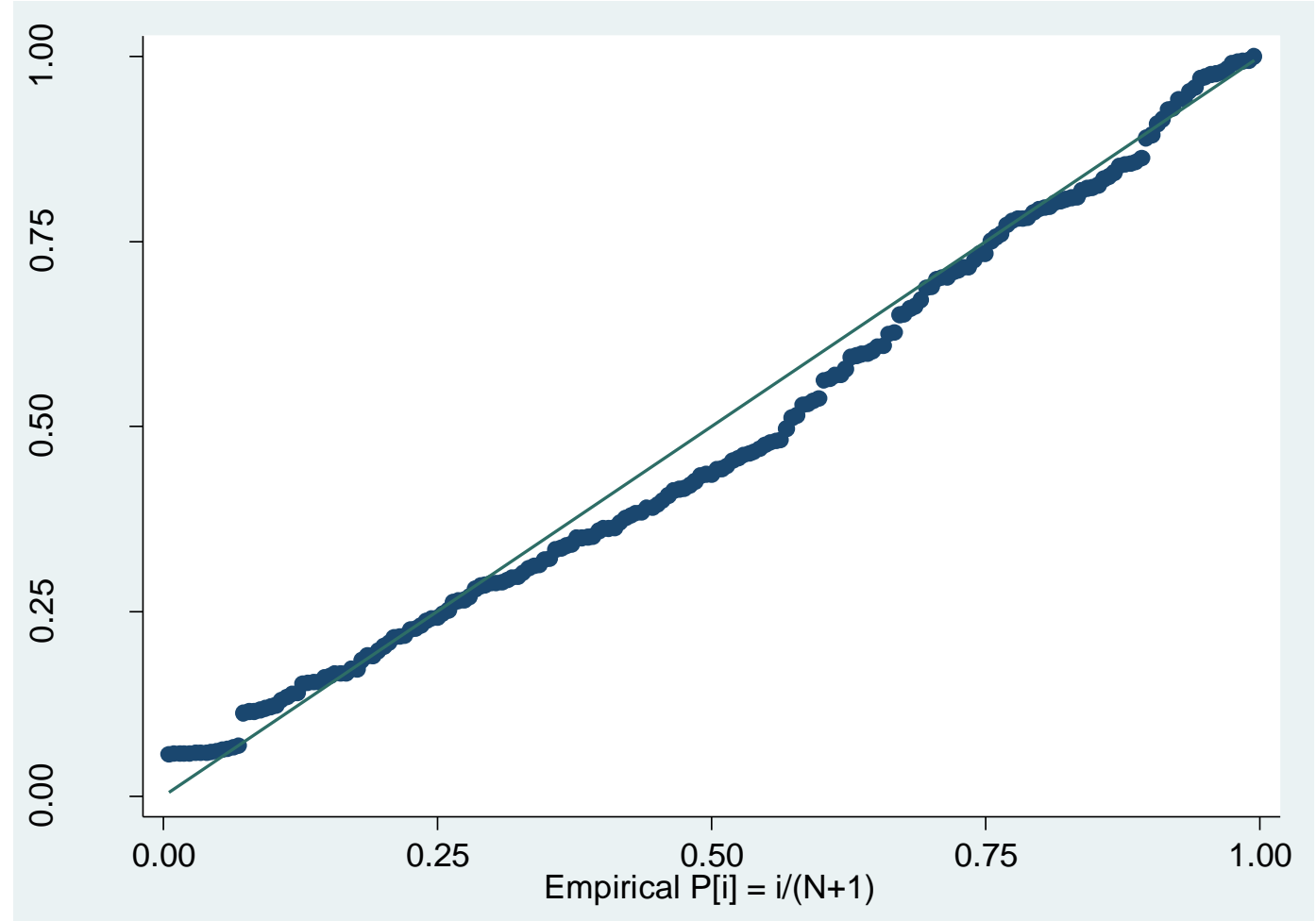

We have used the normal distribution technique called the probability normal distribution and see that it is fairly consistent from start to finish. There is a lot to be said about the model used for our analyses, primarily that of our interaction variable. Nevertheless, this is one avenue in understanding the vastly complex situation in China as it has experienced multiple economic and political policies with different outcomes.

Since the 1970s, China has opened up its market to the outside world while maintaining its political environment as a quasi-communist government with one major political party. Investors, such as the U.S were aware of the risks involved in investing in a country that was considered a foe with completely opposite political beliefs. Nevertheless, the risks were made and the returns proved to be very lucrative for investors. Today, China, mainly on its east coast, is well known for its open economy as 
international trading, primarily its exporting capabilities to both developed and developing countries, have dominated the world. Therefore, China has well over several decades of experience in attracting FDI. It is no surprise to see this variable consistent with the growth literature. However, the next country on the list proves to be quite a challenge to understand.

India is regarded as an emerging economy, although not at the same economic levels as China, but a formidable powerhouse indeed in the next century. It is also the largest democracy in the world with well over 1.1 billion people second to that of China. Both countries share similar traits, such as geographical location and the number of provincial governments. With over thirty provinces, India is also very unique in that it too has its rural and metropolitan areas, and a vast amount of water surrounding it. However, it is very much different from China in both its economical and political stances.

Model 3 provides the information for India with stark results.

\section{Model 3:}

- reg FDI GDP RPCGDP Open

\begin{tabular}{r|crc} 
Source & SS & df & MS \\
\hline $\begin{array}{r}\text { Mode1 } \\
\text { Residua1 }\end{array}$ & 9484.38927 & 3 & 3161.46309 \\
\hline Total & 20966.6564 & 104 & 201.602465
\end{tabular}

Number of obs $=105$

$F(3,101)=27.81$

Prob $>\mathrm{F}=0.0000$

R-squared $=0.4524$

Adj R-squared $=0.4361$

$\begin{array}{lll}\text { Adj R-Squared } & =0.4361 \\ \text { Root MSE } & 10.662\end{array}$

\begin{tabular}{r|rlrrrr}
\hline FDI & Coef. & std. Err. & $\mathrm{t}$ & $\mathrm{P}>|\mathrm{t}|$ & \multicolumn{2}{c}{ [95\% Conf. Interva1] } \\
\hline GDP & -9.195648 & 4.539087 & -2.03 & 0.045 & -18.19998 & -.1913202 \\
RPCGDP & 13.64313 & 6.289281 & 2.17 & 0.032 & 1.166893 & 26.11938 \\
Open & .4478851 & .1119237 & 4.00 & 0.000 & .2258587 & .6699115 \\
-COns & .2409249 & 2.143979 & 0.11 & 0.911 & -4.012153 & 4.494002 \\
\hline
\end{tabular}

We expected its RPC levels to be positive and significant merely due to its democratic value, but we found its RPC levels to be negative and insignificant, not to mention only forty-three percent of the variance is explained in our model. This causes some debate in 
the democracy literature as we assumed that democracies are very capable in governing. However, we need to take into account that India is a developing country unlike that of the U.S where several variables differ dramatically, such as corruption. When comparing democratic countries based on the Corruption Perception Index, India is given a 3.3 and the U.S a 7.1. The lower the number implies the higher the level of corruption perceived in a given country, hence perhaps why India's RPC levels are negative. There is some truth to this that although India is indeed capable of extracting resources from its people, the perceived corruption has plagued its potential from maximizing its abilities to attract FDI. However, another inconsistency lies in the model as GDP is also negative, but significant.

Contrary to the growth literature, we expect GDP to be positive and significant for a country's growth, but in the case of India, it seems as if it is quite the opposite. We find that a one percent change in India's GDP will lead to a nine million dollar decrease in FDI. Model 3 provides a negative relationship relative to FDI, so this would imply that India's growing economy alone does not necessarily attract FDI, but is missing something. From one perspective, this makes sense as the CPI has truly plagued India's appeal to investors, so an increase in economic development may not be enough to give investors the signal to invest right away. We also have to note that India's current GDP level is four trillion dollars, six trillion less than China. This may not be convincing enough for investors to start investing in this country as economic development is well below that of China, and plus, China is the more appealing country for investors. Further, there needs to be some sort of interaction between the ability of a government to extract its resources along with its people's living standards. Hence, we included the interaction variable between RPC and GDP. 
Model 3 provides compelling evidence that RPC and GDP by itself is not enough to positively attract FDI, but the interaction of both variables must be present for investors to invest in India. The interaction variable is indeed positive and significant, not to mention consistent with the China model, hence making us believe that once investors see Indian provincial governments extracting resources from its people for the purpose of economic development, in turn would give the signal to investors to invest in India. We find that a one percent change in India's RPC*GDP will lead to a thirteen million dollar increase in FDI. This is a powerful implication as we have also seen this interaction variable work when all three countries are analyzed. There is something to be said about this as developing countries regardless of its CPI levels can still overcome its reputation and attract FDI by showing investors that its government is committed in improving economic development through effective policy-making. The last point to make about this interaction variable is that other authors have used similar variables to suggest the same goal of attracting FDI, so there is already a growing literature in these interaction variables.

Model 3 also includes one last variable, which is not a surprise in the growth literature. The variable Open Economy was collected and used to determine its consistency in the field, and we found it to be positive and significant in attracting FDI. We find that a one percent change in India's open economy will lead to a four hundred thousand dollar increase in FDI. This reinforces the notion that developing countries need to open up its borders to trade in the international realm in order to attract foreign investments. Now, we can check the model to ensure that it meets the four pillars of statistical analysis. To ensure that our interaction variable does have a significant impact, 
we ran the regression analysis with beta coefficients, and as figure 19 suggests, our interaction variable is the strongest variable to affect FDI.

Figure 19: Model 3 with Beta Coefficients

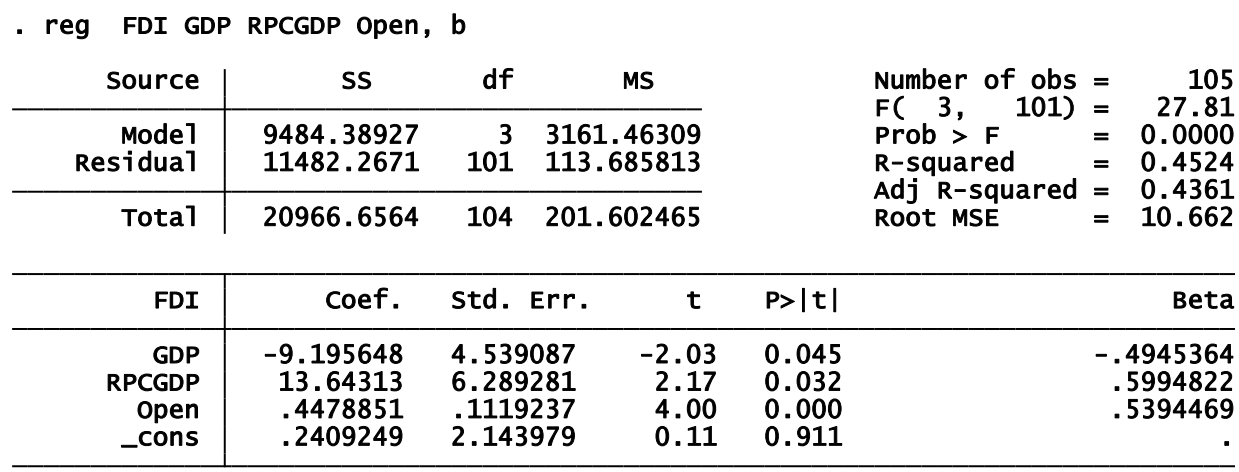

One item to note is the negative relationship between FDI and GDP as we expected it to be positive, however, unlike models 1 and 2, GDP in model 3 is not as signficant as our interaction variable. It is also important to provide the relationship of our dependent variable against our independent variables to see the patterns. Based on the correlation matrix graph, we can see some issues similar to what we experienced in model 2. Graph 16 provides the illustration. 
Graph 17: Correlation Matrix of Model 3

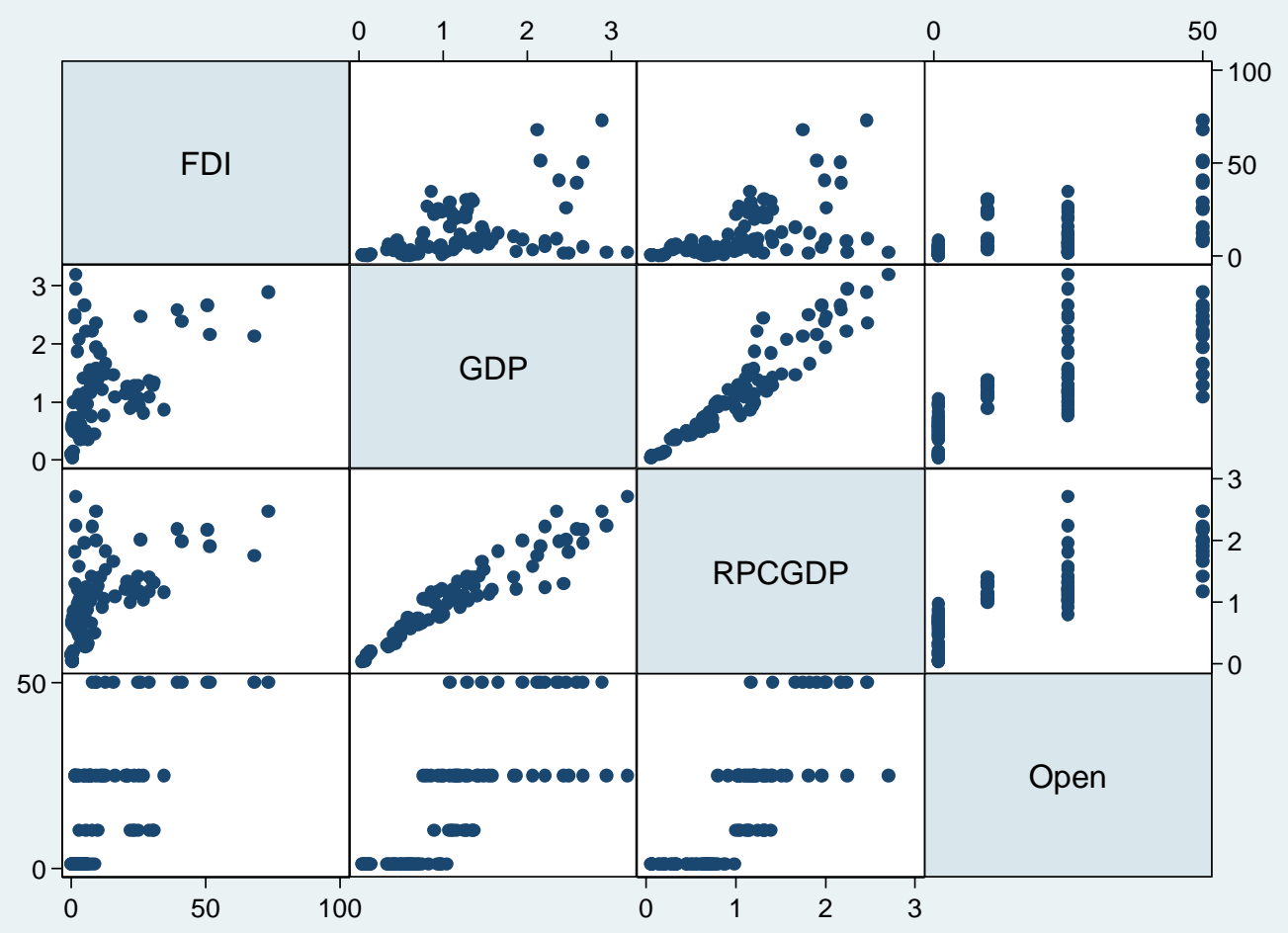

There are a few issues with outliers as depicted in the graph, so we need to check that the observations do not affect our results. We will use the kernel density estimate to check that our model is normally distributed. Graph 17 provides the illustration. 


\section{Graph 18: Kernel Density Estimate of Model 3}

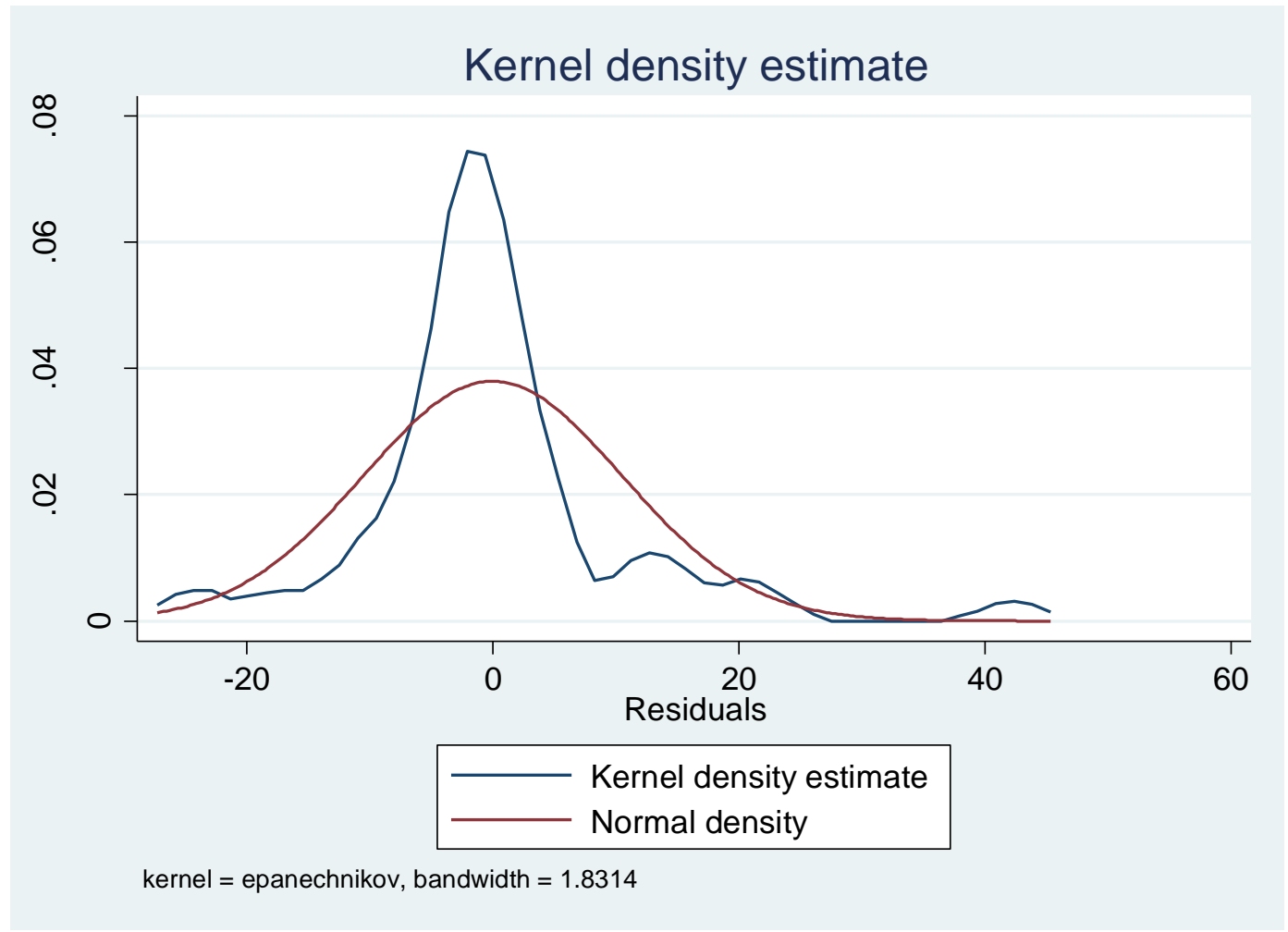

Our graph does look much better than previous models, and we can suggest that our model is normally distributed. The next test is to determine whether our model fulfills the linearity test. The augmented component plus residual tool was used to determine the linearity of each independent variable. Graphs 18 and 19 provide the illustration. 
Graph 19: ACPR Plot of GDP for Model 3

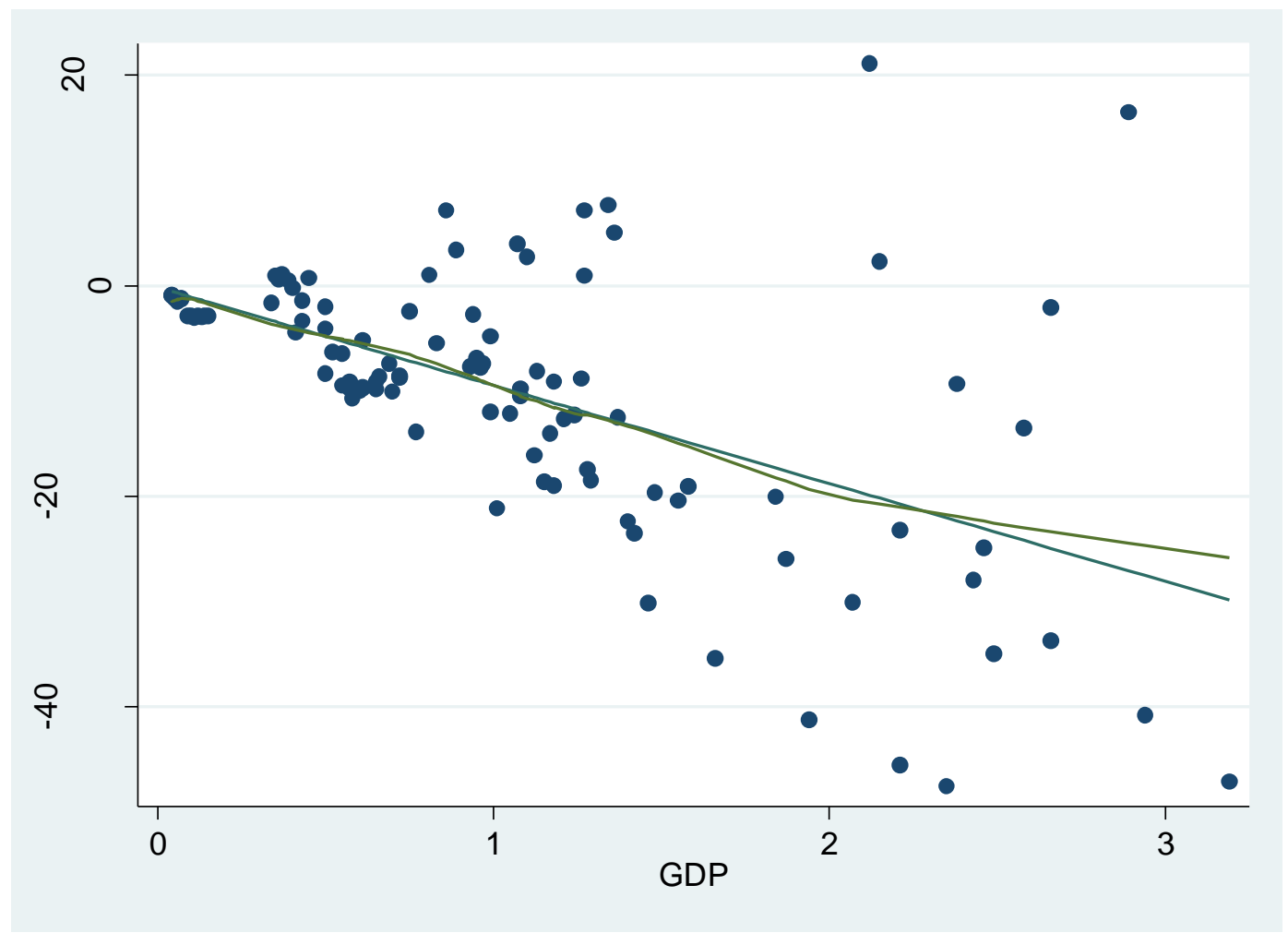

We can definitely see a linear relationship in this graph, although just to mention what was stated earlier, the relationship is indeed a negative one. Nonetheless, we do see a very smooth fitted downward-sloping curve until two where it starts to slowly move away from each other. 
Figure 20: ACPR Plot of RPCGDP for Model 3

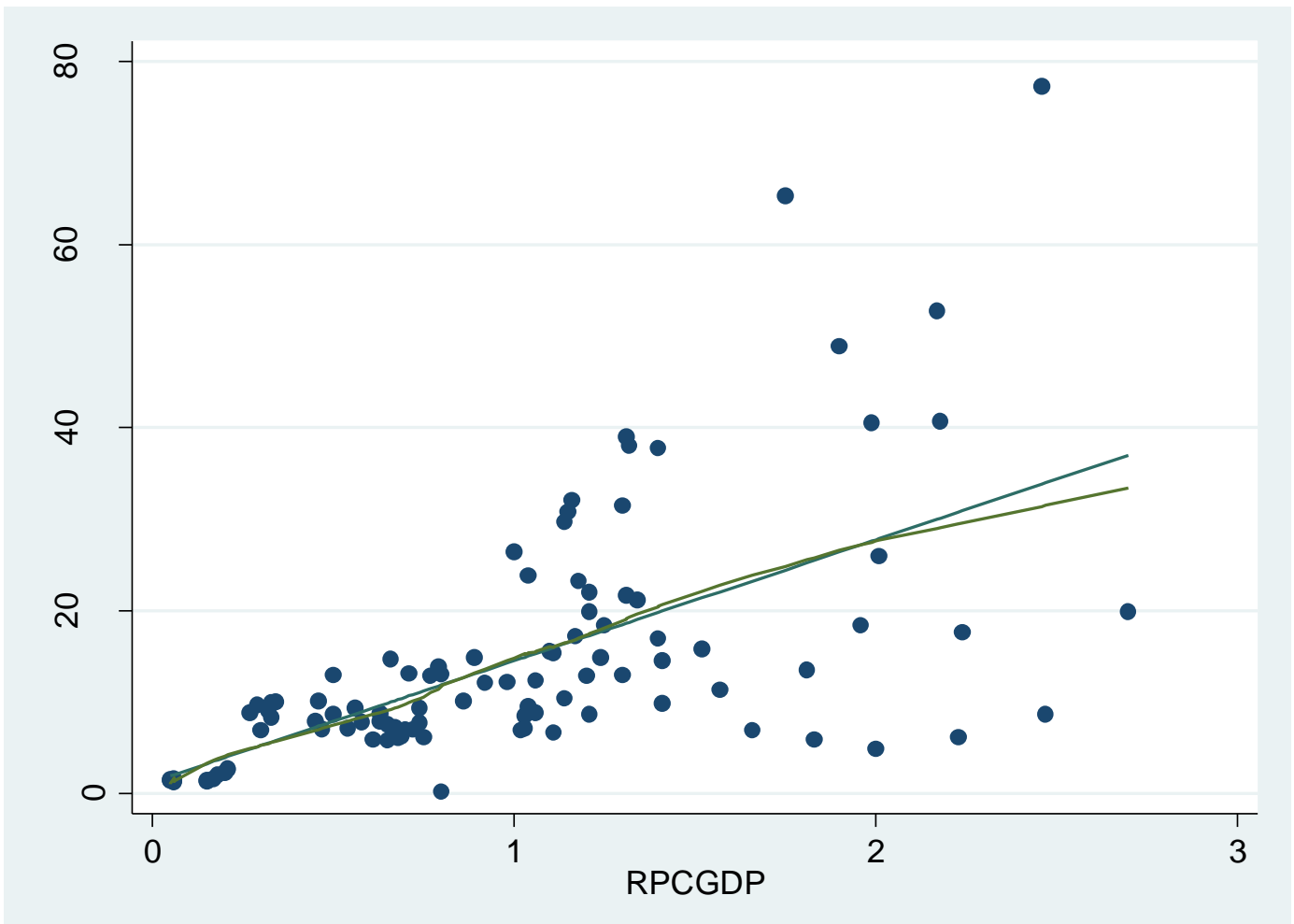

The augmented component plus residual graph for our interaction variable is also linear as we see the slope increase. There is a minor deviation once the variable reaches two, but for the most part, the relationship is indeed linear. We can rest assure that we have fulfilled the second criteria of statistical testing and are ready to test for homoscedasticity. Graph 20 provides the illustration. 
Graph 21: Residuals vs. Fitted Values

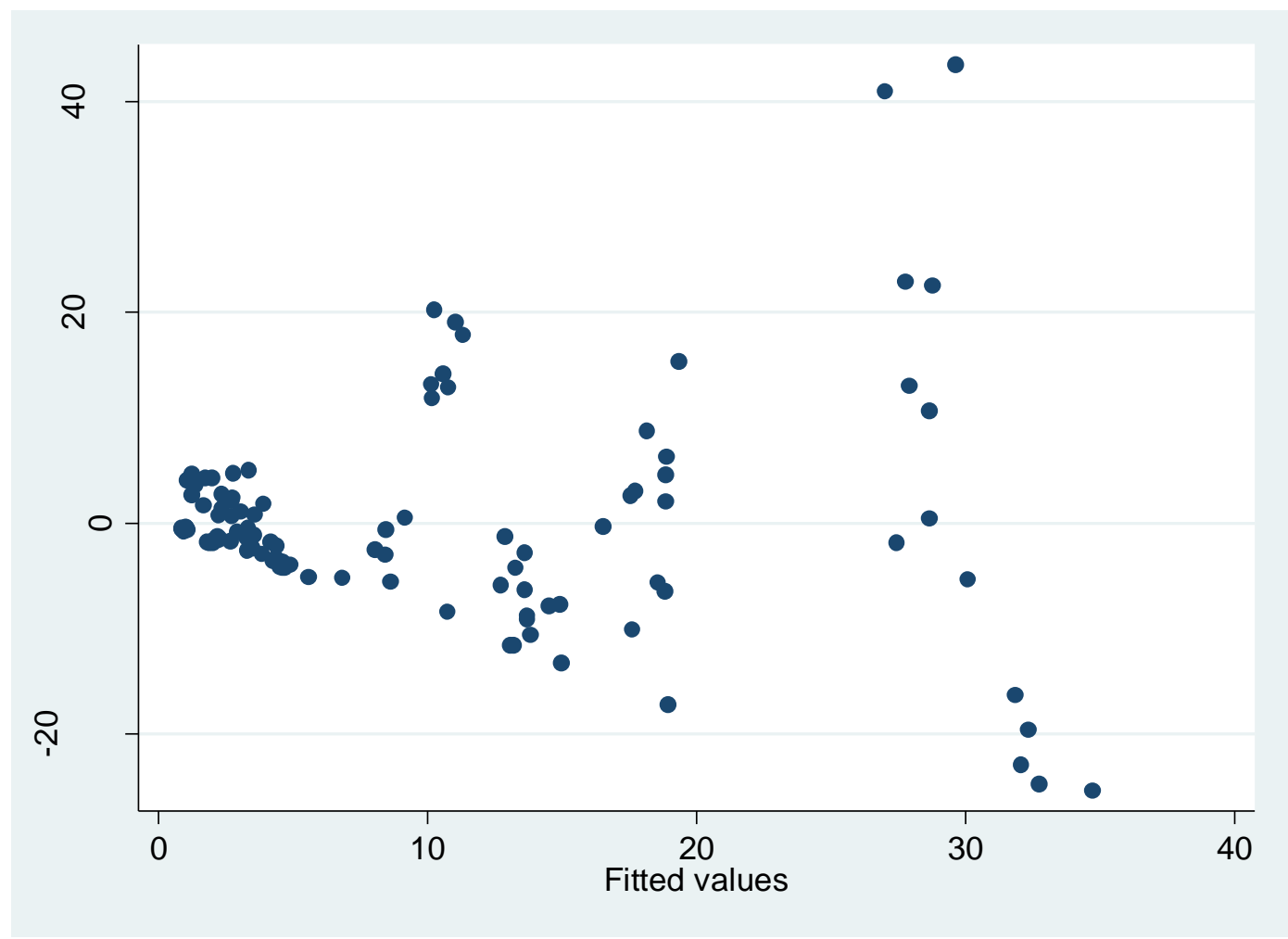

Unlike the tests for normal distribution and linearity, we see an issue with heteroscedasticity. The observations seem to cluster at the beginning of the graph then randomly spread out. However, we will need to run the Breusch-Pagan test to make sure that it is present in our model. Figure 20 provides the heteroscedasticity results.

Figure 20: BP Test for Model 3

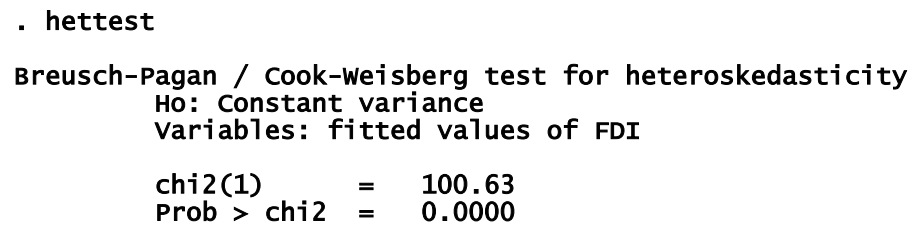

We definitely can reject the hypothesis that our model is homoscedastic. Therefore, we will need to correct this by running our model with robust standard errors. Figure 21 provides the results. 
Figure 22: Robust Standard Errors for Model 3

\begin{tabular}{|c|c|c|c|c|c|c|}
\hline \multicolumn{5}{|c|}{ Linear regression } & $\begin{array}{l}\text { Number of obs } \\
\text { F( } 3,101) \\
\text { Prob }>\text { F } \\
\text { R-squared } \\
\text { Root MSE }\end{array}$ & $\begin{array}{lr}= & 105 \\
= & 10.19 \\
= & 0.0000 \\
= & 0.4524 \\
= & 10.662\end{array}$ \\
\hline FDI & coef. & $\begin{array}{l}\text { Robust } \\
\text { Std. Err. }\end{array}$ & $t$ & $P>|t|$ & {$[95 \%$ conf. } & Interval] \\
\hline $\begin{array}{r}\text { GDP } \\
\text { RPCGDP } \\
\text { Open } \\
\text { _cons }\end{array}$ & $\begin{array}{r}-9.195648 \\
13.64313 \\
.4478851 \\
.2409249\end{array}$ & $\begin{array}{l}4.939281 \\
7.300044 \\
.144118 \\
2.034421\end{array}$ & $\begin{array}{r}-1.86 \\
1.87 \\
3.11 \\
0.12\end{array}$ & $\begin{array}{l}0.066 \\
0.065 \\
0.002 \\
0.906\end{array}$ & $\begin{array}{r}-18.99385 \\
-.8381902 \\
.1619937 \\
-3.794819\end{array}$ & $\begin{array}{r}.602558 \\
28.12446 \\
.7337765 \\
4.276669\end{array}$ \\
\hline
\end{tabular}

We do see a slight issue when running this model with robust standard errors as both our variables, GDP and RPCGDP are now statisticall insignificant at the 95\% level. This can cause some concern as our original model suggest that our variables, particularly our interaction variable is positively correlated with FDI. We can either check our observations to ensure that we do not have missing observations, or we can simply omit GDP in our model as there is the other concern for multicollinearity. Figure 21 provides the test results for multicollinearity.

Figure 23: Variance Inflation Inflator for Model 3

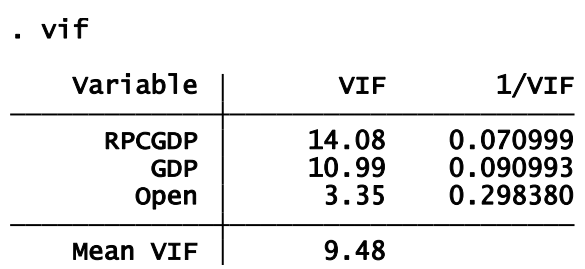

As suspected, we do see a very strong correlation between our independent variables, so one technique to solve this issue is to omit GDP. Figure 22 provides the new variance inflation inflator. 
Figure 24: Variance Inflation Inflator without GDP for Model 3

\begin{tabular}{|c|c|c|}
\hline Variable & VIF & $1 / \mathrm{VIF}$ \\
\hline $\begin{array}{r}\text { Open } \\
\text { RPCGDP }\end{array}$ & $\begin{array}{l}3.33 \\
3.33\end{array}$ & $\begin{array}{l}0.300210 \\
0.300210\end{array}$ \\
\hline Mean VIF & 3.33 & \\
\hline
\end{tabular}

We now can move on as our model does not show any signs of multicollinearity. Again, we saw this similar issue with models 1 and 2, and omitting GDP from both models solved the issue of multicollinearity. If this trend continues, we can expect it to occur again in model 4 for Indonesia.

We have to keep in mind that regardless of India's open economy spanning back to its independence from Great Britain in the mid-twentieth century, it took on a combination of western style policies with socialist practices, which became known as economic socialism. This did not sit well with investors, as there was the uncertainty of what type of economic industry India was going to become, so a cautious optimism ensued. However, the results took several decades long to finally appeal to the international community that it is a reputable and safe country to invest in. Today, India is an economic powerhouse, primarily in the realms of service as they provide assistance to several developed countries, such as the U.S in many technology related fields. Nevertheless, India does need several variables present to effectively attract FDI and continue to take its place in the international market as an economic powerhouse rather than having an open economy alone as there must be a commitment made by the Indian governments to improve economic development. The last developing country tested is Indonesia, and surprisingly had similar results with India.

Indonesia like China and India has thirty provinces in this vast archipelago system. And unlike China and India where one of its coasts consist of land and the other 
water, its provinces are scattered around and all are surrounded by water. Although there are advantages of having water accessibility, it can also hinder economic investments and trade as a direct route may be absent not to mention the lack of ports in smaller provinces. In our study, we found interesting results with Indonesia closely resembling that of India. Model 4 provides the breakdown of each variable used relative to FDI. We also see our R-square at 0.65 , nearly twice as strong as India's R-square.

\section{Model 4:}

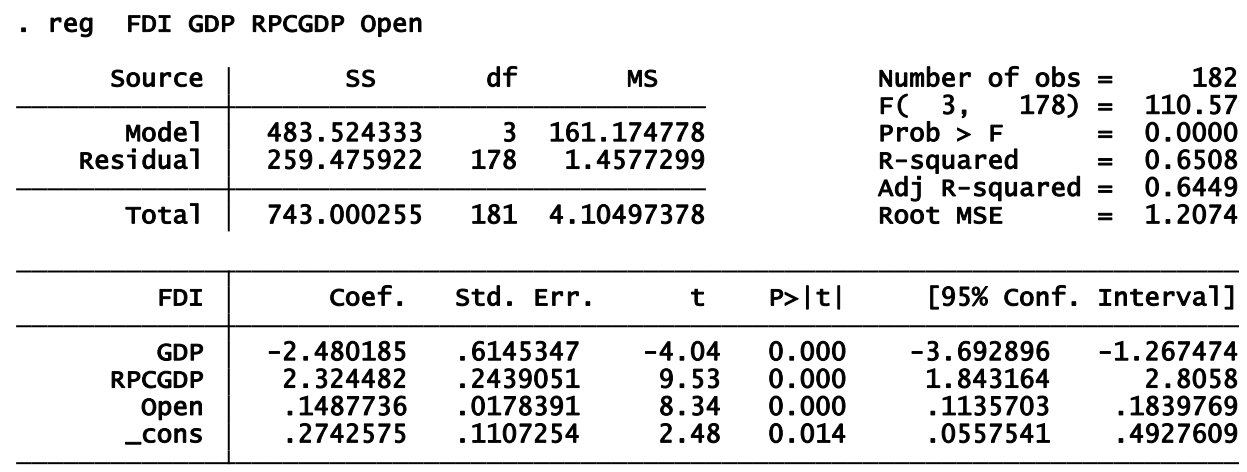

Similar to India, Indonesia's RPC level is negative and insignificant, which leads us to believe that the same thing happening in India is happening in Indonesia, which could be the CPI result. The CPI level for India is at a 3.3 while Indonesia is at 3.1 , so the corruption perception is much higher in Indonesia. This could again possibly explain the negative relation to FDI as capable governments may not necessarily know how to effectively extract its resources from its people that would in turn lead to effective policies, thereby appealing to foreign investors. Another similarity between India and Indonesia is their GDP's negative and significant relation relative to FDI. We find that a one percent change in Indonesia's GDP will lead to a two million dollar decrease in FDI. Although the theoretical sign does not support the growth literature, we can conclude by 
saying that GDP alone is insufficient in attracting FDI. Nevertheless, this reminds us of the importance of an interaction variable between RPC and GDP.

The more interesting finding is that of the interaction variable between RPC and GDP. Similar to the results found in China and India, Indonesia is positive and significant. We find that a one percent change in Indonesia's RPC*GDP will lead to a two million dollar increase in FDI. This suggests that the interaction variable is necessary in attracting FDI into this developing country even though it has been plagued by the CPI result. And to reemphasize the notion of political systems, Indonesia is considered to be a democratic republic just like India. There is something to be said about CPI and democracies, which can be further explained in a different research.

The interaction variable sheds light into why developing countries find it such a challenge to attract FDI as most of the developing countries do not have capable governments able to extract resources from its people for the purpose of improving economic development. Our model suggests that a one percent increase in RPC*GDP will lead to a two million dollar increase in FDI. In addition, this interaction variable also suggests that certain variables alone, such as RPC and GDP are insufficient in attracting FDI, hence there must be something more than that. We mentioned earlier that Indonesia's GDP level is nine trillion dollars less than China's, which would make any investor choose the latter as economic development is much better in China.

Model 4 also provides the results for the variable Open Economy, and similar to China, Indonesia's open economy is positive and significant. We find that a one percent change in Indonesia's open economy will lead to a one hundred thousand dollar increase in FDI. Again, this supports the theoretical sign in the growth literature that a developing country needs to have open markets as one of the requisites in attracting FDI. However, 
one point to make regarding open economies is Indonesia's archipelago system. Unlike China and India where both countries are not only neighboring countries, but are massive in terms of land mass and population, each have mega seaports known to the international community. This truly provides other countries the ability to invest and trade using direct routes to China's and India's massive coastlines. Indonesia only consists of four major ports, while China has over 100 ports and India thirteen ports. This is truly a big difference when it comes to economic development. In addition, there are many provincial islands in Indonesia that are untouched where primitive groups of people still reside living as they did for hundreds of years; Indonesia as a whole is just starting to open its economy.

We also have to take into account that even though Indonesia opened up its economy in the late 1960s, it was also the hardest hit during the 1997 financial crisis, which truly made this country notorious as a place to invest as billions of dollars were lost, so investors have not forgotten about that event and will continue to play a cautious role when investing in Indonesia.

Now, we can check to see if our model fulfills the four tests in statistical testing. We also need to see how influential our variables are, particularly our interaction variable. Figure 23 provides model 4 with beta coefficients. 
Figure 25: Model 4 with Beta Coefficients

- reg FDI GDP RPCGDP Open, b

\begin{tabular}{r|crr} 
Source & SS & df & MS \\
\hline $\begin{array}{r}\text { Mode1 } \\
\text { Residual }\end{array}$ & 483.524333 & 3 & 161.174778 \\
\hline Total & 743.000255 & 181 & 4.10497378
\end{tabular}

Number of obs $=182$

$\mathrm{F}(3,178)=110.57$

Prob $>\mathrm{F}=0.0000$

R-squared $=0.6508$

$\begin{aligned} \text { Adj R-squared } & =0.6449 \\ \text { Root MSE } & =1.2074\end{aligned}$

\begin{tabular}{r|rcrcr}
\hline FDI & Coef. & std. Err. & $t$ & P $>|t|$ & Beta \\
\hline GDP & -2.480185 & .6145347 & -4.04 & 0.000 & -.4736746 \\
RPCGDP & 2.324482 & .2439051 & 9.53 & 0.000 & .8982839 \\
Open & .1487736 & .0178391 & 8.34 & 0.000 & .5645853 \\
_Cons & .2742575 & .1107254 & 2.48 & 0.014 &. \\
\hline
\end{tabular}

We can definitely a larger influence our interaction variable has on FDI. From the previous models, we only saw a range of up to fifty-percent, but for model 4, it is nearly ninety percent, so we can definitely suggest that our interaction variable truly influences FDI in Indonesia. Graph 23 provides a snapshot of a graphical representation of each of our variables in a matrix.

Graph 22: Correlation Matrix of Model 4

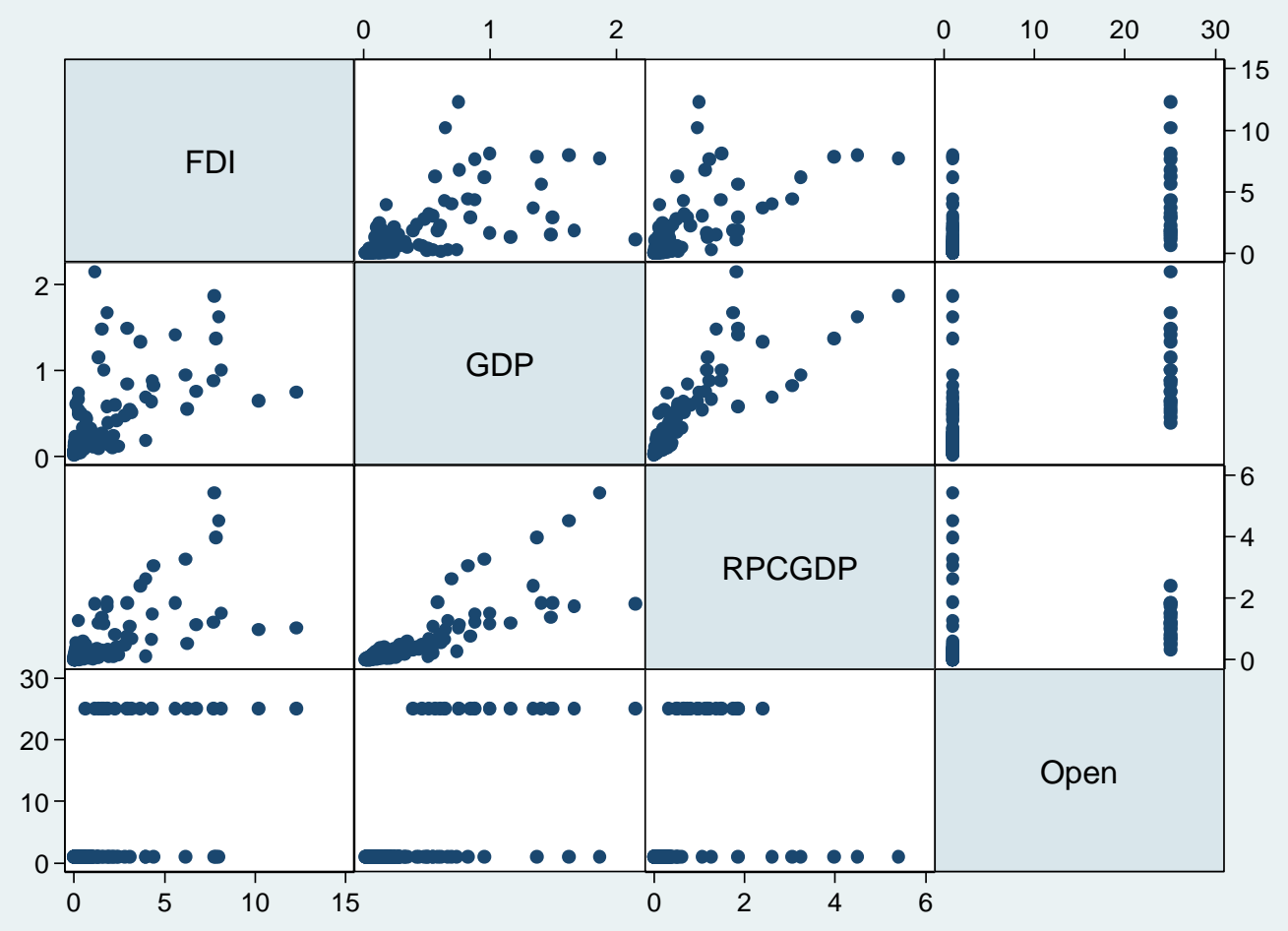


It is no surprise that we do see minor issues similar to our previous models, so we will need to check if our model is normally distributed. For this, we will test for normality using the kernel density estimate. Graph 22 provides the illustration.

\section{Graph 23: Kernel Density of Model 4}

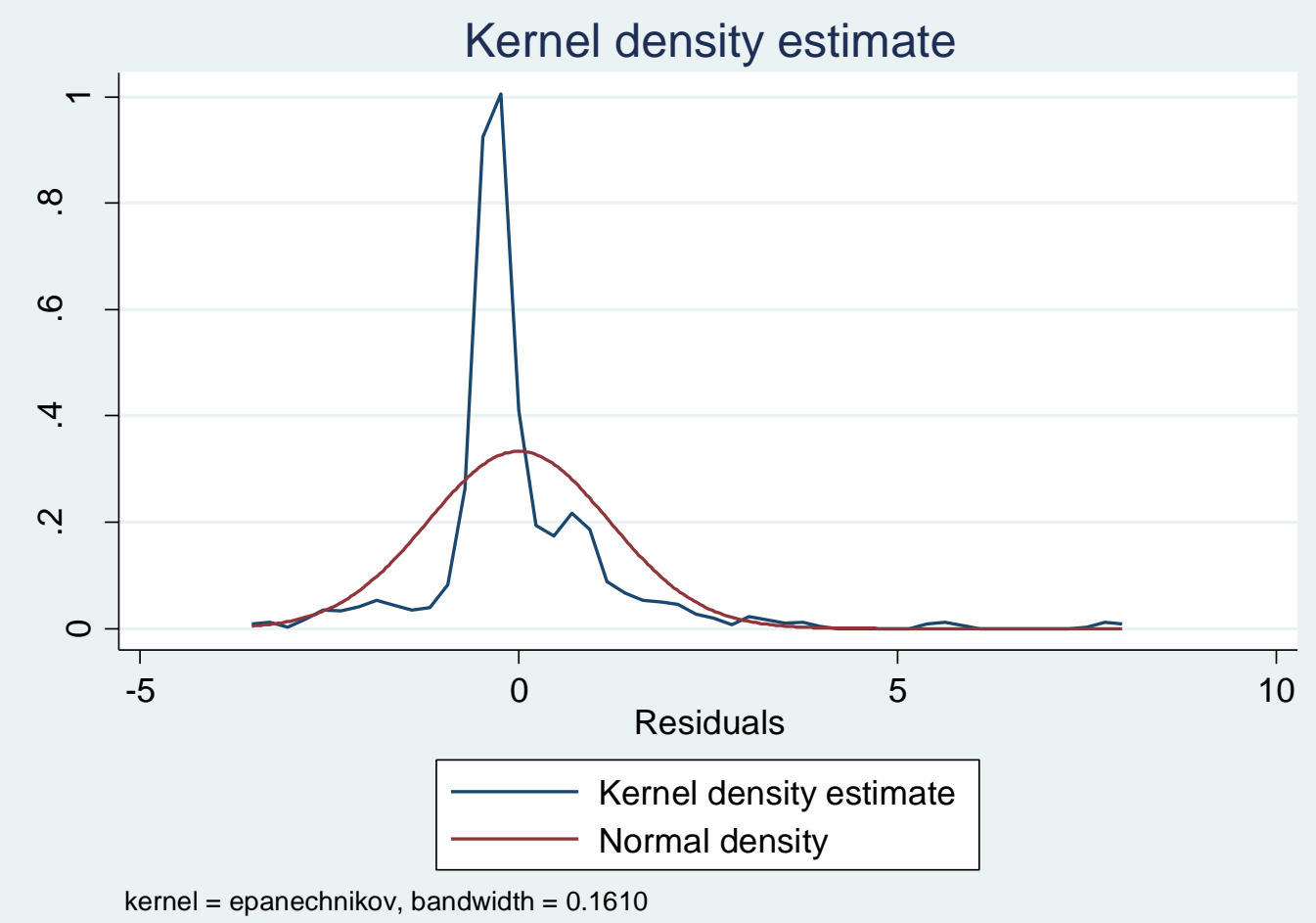

We do see a normally distributed model with minor issues, but overall, does fulfill the criteria of a normal distribution. Next, we need to check if our model obeys the rule of linearity. Graphs 23 and 24 provides the illustration for both GDP and RPCGDP 


\section{Graph 24: ACPR Plot of GDP for Model 4}

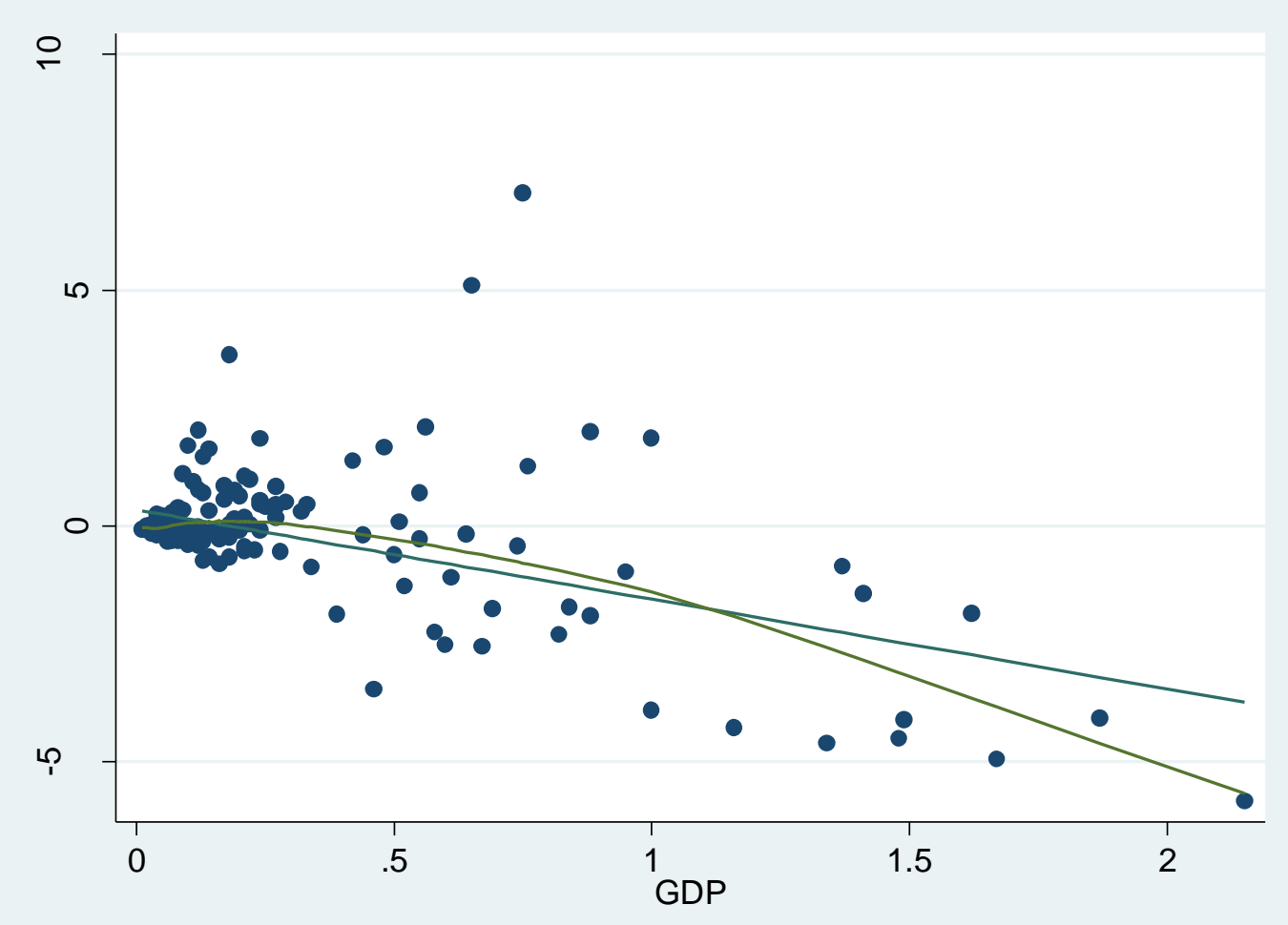

We do see some consistency in this graph, and similar to model 3, we do have GDP with a downward slope indicating a negative relationship with FDI. In addition, we do see a slight deviation once we surpass one, but for the most part, it does provide a faily consistent linear curve. 


\section{Graph 25: ACPR Plot of RPCGDP for Model 4}

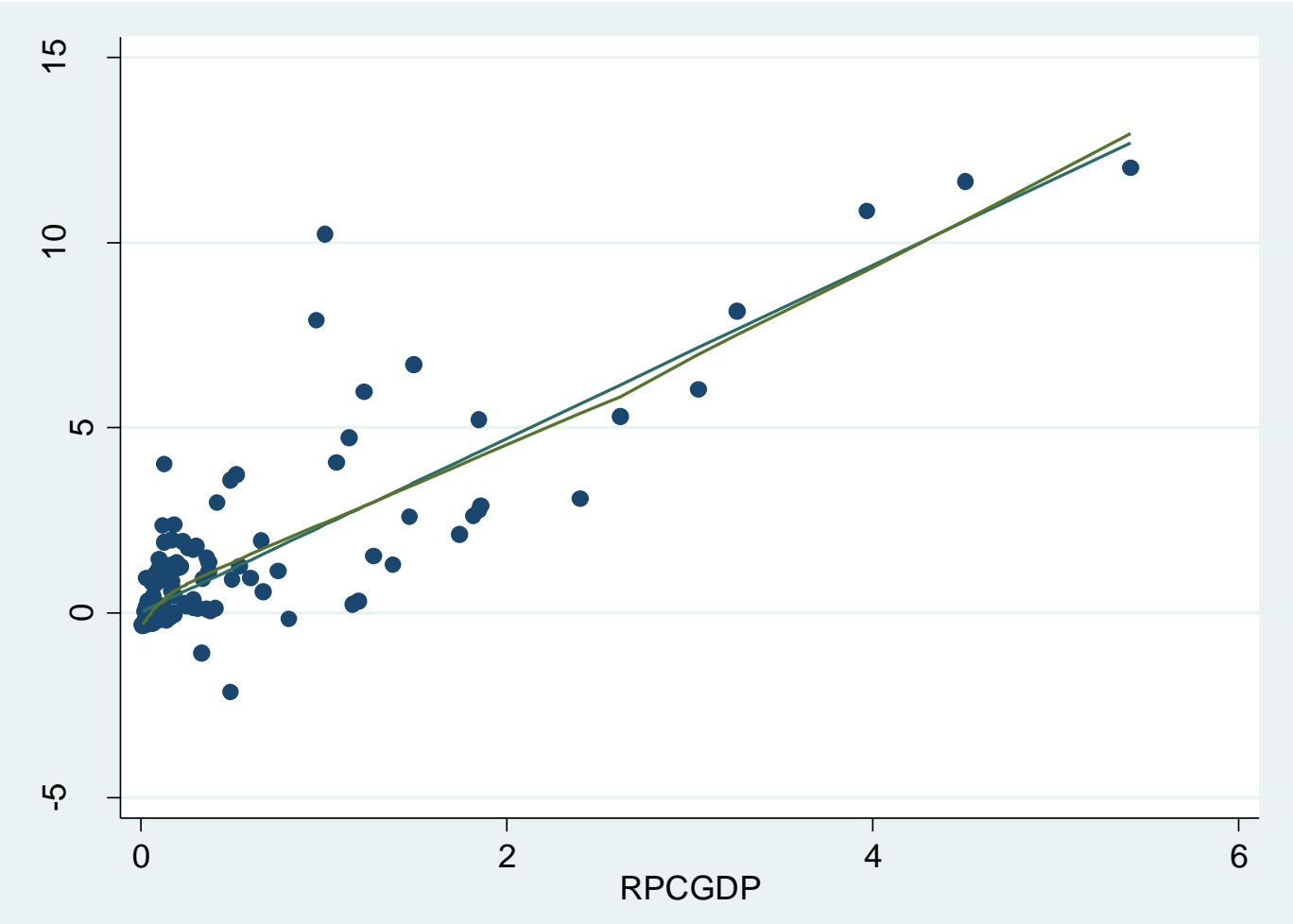

We have a much better depiction of a linear curve when using our interaction variable. Unike model 3, we do not see any deviation at any point, implying that we do have a linear relationship with our interaction variable. We can now check for heteroscedasticity. Graph 25 visually tests for heteroscedasticity while figure 24 provides the results of the Breusch-Pagan test. 
Graph 26: Residuals vs. Fitted Values

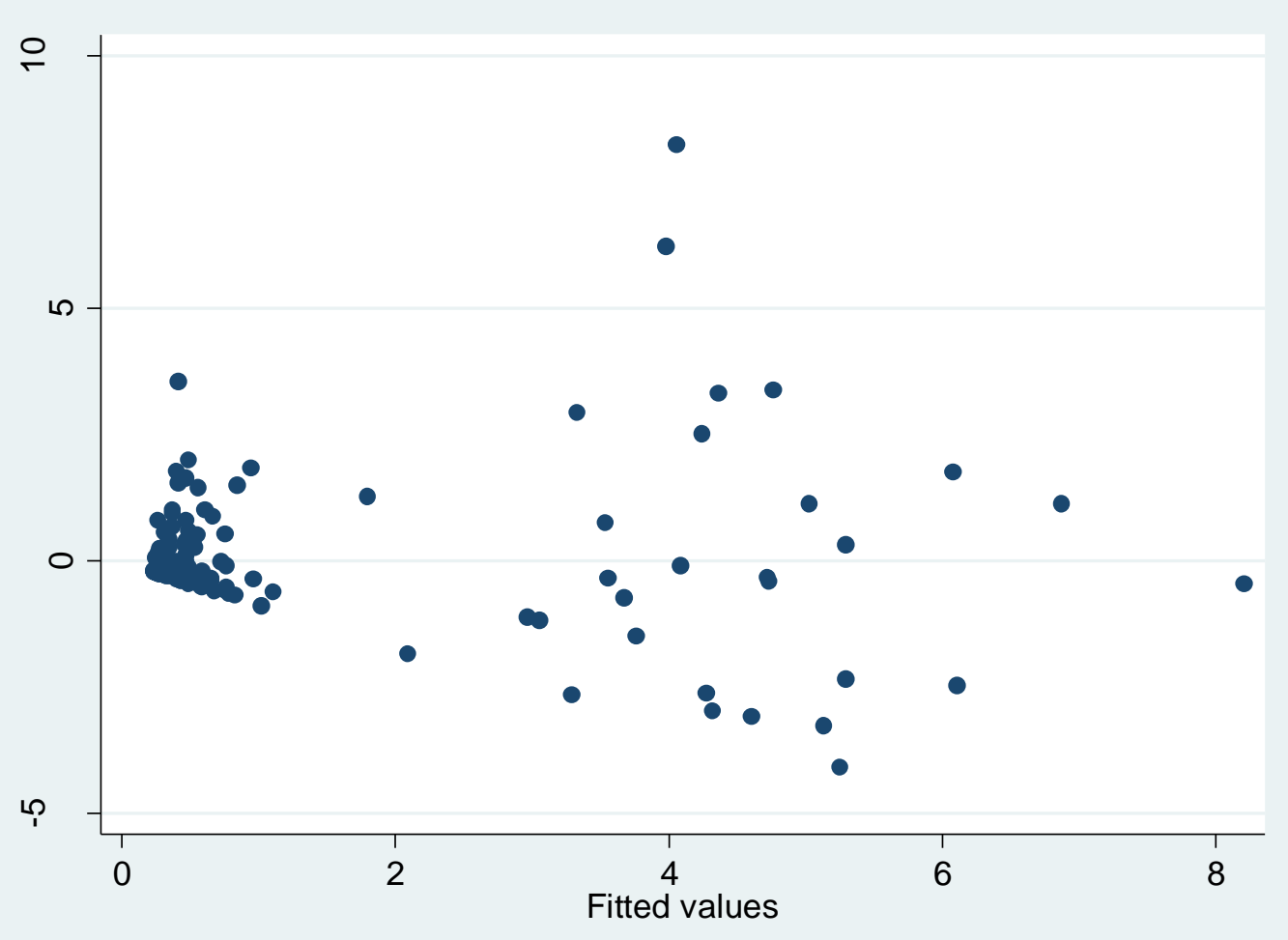

Figure 26: BP Test for Model 4

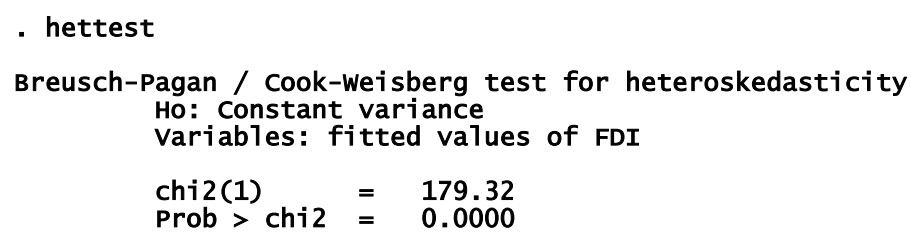

Again, we see a similar trend from the previous models that our observations start to cluster at the beginning of the graph then slowly deviate. Although this graph provides very little evidence of constant variance, not to mention the Breusch-Pagan test indicating that we have heteroscedasticity, we will need to address this issue by running model 4 with robust standard errors. Figure 25 provides the results. 
Figure 27: Model 4 with Robust Standard Errors

\begin{tabular}{|c|c|c|c|c|c|c|}
\hline \multicolumn{5}{|c|}{ Linear regression } & $\begin{array}{l}\text { Number of obs } \\
\mathrm{F}(3,178) \\
\text { Prob }>\mathrm{F} \\
\text { R-squared } \\
\text { Root MSE }\end{array}$ & $\begin{array}{rr}= & 182 \\
= & 74.49 \\
= & 0.0000 \\
= & 0.6508 \\
= & 1.2074\end{array}$ \\
\hline FDI & coef. & $\begin{array}{l}\text { Robust } \\
\text { Std. Err. }\end{array}$ & $t$ & $P>|t|$ & [95\% conf. & Interva1] \\
\hline $\begin{array}{r}\text { GDP } \\
\text { RPCGDP } \\
\text { Open } \\
\text { _cons }\end{array}$ & $\begin{array}{r}-2.480185 \\
2.324482 \\
.1487736 \\
.2742575\end{array}$ & $\begin{array}{l}.9320194 \\
.3135704 \\
.0402672 \\
.0769293\end{array}$ & $\begin{array}{r}-2.66 \\
7.41 \\
3.69 \\
3.57\end{array}$ & $\begin{array}{l}0.009 \\
0.000 \\
0.000 \\
0.000\end{array}$ & $\begin{array}{r}-4.319414 \\
1.705688 \\
.069311 \\
.1224468\end{array}$ & $\begin{array}{r}-.6409553 \\
2.943276 \\
.2282362 \\
.4260682\end{array}$ \\
\hline
\end{tabular}

We can see that GDP is negatively correlated with FDI, while our interaction variable of RPCGDP continues to be significant displaying the correct theoretical sign. Since we had similar issues with previous models, we can also assume that GDP and RPCGDP might be highly correlated, which can enable us to omit GDP. We test for multicollinearity and did find a similar trend with previous models in figure 26.

Figure 28: Variance Inflation Inflator for Model 4

\begin{tabular}{|c|c|c|}
\hline Variable & VIF & $1 / \mathrm{VIF}$ \\
\hline $\begin{array}{r}\text { GDP } \\
\text { RPCGDP } \\
\text { Open }\end{array}$ & $\begin{array}{l}7.02 \\
4.53 \\
2.34\end{array}$ & $\begin{array}{l}0.142431 \\
0.220837 \\
0.428090\end{array}$ \\
\hline Mean VIr & 4.63 & \\
\hline
\end{tabular}

Although GDP is not as high as other models where we experience over ten, we still have to be concern that GDP is showing a variance inflation inflator of seven. Therefore, by omitting GDP, we can control for multicollinearity. Figure 27 provides the variance inflation inflator without GDP.

Figure 29: Variance Inflation Inflator without GDP for Model 4

\begin{tabular}{|c|c|c|}
\hline Variable & VIF & $1 /$ VIF \\
\hline $\begin{array}{r}\text { Open } \\
\text { RPCGDP }\end{array}$ & $\begin{array}{l}1.16 \\
1.16\end{array}$ & $\begin{array}{l}0.863044 \\
0.863044\end{array}$ \\
\hline Mean & 1.16 & \\
\hline
\end{tabular}


We can definitely see a big difference when omitting GDP from the model. We also have to take note that dropping GDP in the previous models actually improved our model while maintaining the important premise of this study that the interaction of GDP and RPC is necessary to effectively attract FDI.

Overall, there seems to be many similarities and differences among each country, but we can definitely attest to the importance of the interaction between RPC and GDP as a compelling variable to suggest a developing country's ability to effectively attract FDI. We can also note that most of the variables used do support the growth literature by its theoretical signs and its significance, especially in the case of China. Further, we have analyzed a long list of variable outcomes that can be used in policy making for each provincial government of each country as we have examined the dataset results when all three countries are combined and individually.

Again, to revisit when all three countries are combined, strong governments alone do not necessarily attract FDI, rather strong governments need strong economic policies to effectively attract FDI. We see consistent results with the interaction variable of RPC*GDP, but when each country is analyzed, we see different results. Going back to our initial premise, as long as there is a commitment made by the government to improve economic development, it will attract FDI. The main difference among the models is the notion that both India and Indonesia are democracies while China is an autocracy. Our models suggest that autocracies have a negative impact in attracting FDI than do democracies, but we need to note that China is unlike any autocratic governmental system as it has a proven track record of high levels of FDI for several decades. We also need to note that although India and Indonesia are both democracies, they are considered to be developing nations, which are very different from a developed nation, such as the 
U.S, Great Britain, and France, so it may be safe to say that democracies have a positive impact in attracting FDI than do autocracies, but strictly speaking for developed democratic nations. Plus, these two countries were given very low CPI levels making investors think twice of investing their capital in a highly corrupt country, and we see their GDP about three times less of China's GDP, so it would make sense for any investor to take their chances in a developing country where there is less corruption and economic development.

To further compare our models, we found in Model 2 that China's GDP level is positive and significant, which is consistent in the growth literature. However, in Models 3 and 4, we found India and Indonesia's GDP levels negative and significant, which draws to one conclusion that both of these countries GDP are detracting FDI. In addition, However, all four models suggests that an open economy is key in attracting FDI as our results were positive and significant, which also supports the growth literature.

Overall, it was no surprise to see the interaction variable of RPC and GDP consistent for each individual country and all three countries combined in our models. However, we need to keep in mind that each country is vastly different from one another and varies in terms of economic development. Nevertheless, our results suggest that developing countries in general can become an economic powerhouse, but must have a combination of high levels of RPC and increasing levels of GDP, an open economy, and more importantly, the commitment to pursue economic development policies. 


\section{CHAPTER V}

\section{CONCLUSION}

Our analyses provide support to our hypothesis: the interaction of RPC and economic growth leads to provincial governments in developing countries to effectively attract FDI. The results will allow future researches to examine the conditions between the interaction variable, and how to effectively attract FDI. The implications are as follow:

1. Provincial governments with high levels of RPC alone are insufficient to attract FDI. The theoretical sign and insignificance of RPC in model 1 suggests that strong governments do not necessarily attract FDI as strength alone may not translate to effective policies to improve the standard living of its country. Overall, provincial governments in developing countries with a combination of economical and political policies are in a very good position to attract FDI.

2. Provincial governments in developing countries with a combination of high RPC levels and a commitment to economic policy through economic growth lead to effectively attracting FDI. Models 1, 2, 3, and 4 provide the correct theoretical sign and significance. This accounts for both analyzing all three developing countries (China, India, and Indonesia) combined and individually. These results suggest that an interaction variable of RPC and economic growth is needed to jumpstart a provincial government's ability to attract FDI.

3. On average, democracies seem to attract FDI at a better rate than autocracies. Model 1 provides the analyses for this claim, but we need to keep note of the developing countries economical and political history along with its perception of corruption by the 
international community. Models 2, 3, and 4 entail a different perspective from this claim.

4. A developing country's economical and political history does matter when attracting FDI. Models 2, 3, and 4 provide the analyses for China (autocratic), and India and Indonesia (democratic) for GDP as significant and theoretically positive and negative, respectively. This suggest that China is unlike any other autocratic developing country as it has established itself since the mid-twentieth century as a growing Asian giant with a lot of economic potential. Today, China is number two behind the U.S and continues to experience record growth rates each year. Secondly, China is not seen as a highly corrupt country relative to other autocratic developing countries as evidence by its CPI levels. Lastly, when comparing China as a country, we can see its national governmental level more on the autocratic side, but many of its provincial governments are in fact exercising democratic norms within its borders. As for India and Indonesia, both countries have been plagued by its past economic and political histories. Although India is democratic nationally, it has its share of problems, such as its high levels of corruption and political instability. This does not sit very well for many investors. Its CPI level is higher than China indicating that corruption is more prevalent in India. Plus, India still faces a stalemated war with Pakistan in which the tensions today have increased, especially for the 2008 Mumbai Attacks. As for Indonesia, its corruption perception has also plagued its abilities in attracting FDI as its CPI levels are higher than both China and India. In addition, Indonesia was hit hardest from the 1997 Asian Financial Crisis that led to record inflation rates nearly $80 \%$, rapid currency depreciation of the rupiah, and a severe economic contraction that decreased real GDP by more than $13 \%$. This gave international investors little faith in re-investing in a plague developing country with very 
little promise. Indonesia today is doing much better than a decade ago, but with everything that has taken place, it will take time for its economic wounds to heal for investors to start investing again.

5. Provincial governments in developing countries do need an open economy to attract FDI. Models 1, 2, 3, and 4 show the correct theoretical sign and significance, and is seen as a complement to our interaction variable of RPC and GDP. This suggests that a developing country with high levels of RPC and a strong commitment to economic policies, along with an open economy will be in a better position to attract FDI.

There are a lot of positive outcomes in terms of policy wise for each developing country. As suggested, an interaction variable of RPC and GDP is necessary to effectively attract FDI. This gives the opportunity for each provincial government to invest in its domestic market thereby hopefully controlling for corruption. Many times we see provincial governments tied down to corrupt practices as they do not have the proper checks and balance system in place. However, this will make provincial governments realize that they can compete with more successful provinces by focusing on sound economic policies rather than self-interest. We can also analyze the potential outcomes that its people will gain, such as better wages, the creation of a middle class, and a higher economic return. It makes perfect sense for any institutions to invest a little as the long-term rewards are greater for society as a whole. In addition, when looking at all three developing countries, one thing stands out which are the abundance of untapped natural resources.

China's provinces has long been known to have raw materials waiting to be extracted, such as the provinces of Gansu and Qinghai, which are known to have a laundry list of minerals from coal and crude oil, to copper and chromium. These are just 
four examples of raw materials that are in high demand in the twenty-first century. In fact, Gansu province itself could focus on policies to extract crude oil from the ground, and use it for itself and sell in the market. This will assist the province to improve infrastructure that is essential for both domestic and international investors along with MNCs to get from one point to another. At the rate of their growth, we should be able to see a much more economically successful Gansu province that can compete with the more well-known provinces in China, such as Hainan and Guangdong.

India also offers a vast number of raw materials that its own provincial government can effectively extract and start building its domestic economy. Provinces such as Rajasthan are a great example of what is lacking in terms of sound economic policies. It is the state with the second largest source of cement, which is needed to build roads and highways throughout the province. However, we do not see enough effort by the provincial government to capitalize and exploit this resource. We all know how important building infrastructure is as it connects the world to one's society, and more importantly, it allows goods to be transported by both domestic and foreign producers for consumers to purchase. Further, something as simple as extracting the resources to invest in one's economy will greatly return a higher reward in the long-run, therefore it makes perfect sense for these provinces to start adopting sound domestic economic policies.

Indonesia also has plenty of islands that are uninhabited with an abundance of raw materials. The islands in the east side of the country in the provinces of Maluku, Irian Jaya, and Papua are prime examples. However, these provinces are very much underdeveloped that it does not have the basic necessities that we would expect, such as aqueducts, sewage system, etc. Nevertheless, this should be the opportunity that each provincial government is waiting for. Take for example Papua, which has the largest 
concentration of forest in Indonesia. The provincial government can focus on policies that would allow the extraction of timber to sell in the market, thereby generating revenue up to seventy billion dollars a year, which is a large amount of sum for a province with just under three million residents. This can truly boost its domestic economy as the revenue generated along with the taxes collected from the people can build infrastructure, which it is in desperate need of. Secondly, Papua also has the largest gold mine in the world, and since the value of gold continues to rise in the market, it makes perfect sense to extract this resource to generate revenue. The opportunities are there, but there needs to be the initiative made by the government to want to build its economy, which is usually plagued by corruption and the lack of a checks and balance system. Nevertheless, if these provincial governments in each developing country take advantage of the raw materials it possesses, we can definitely see a rise in both economic and population growth, thereby effectively attracting foreign investments.

Our findings have a lot of potential to extend this literature in other developing countries. It would be interesting to analyze more countries based on geographic locations to see how its government impacts on FDI, and whether RPC alone is sufficient or insufficient in attracting FDI. Since our developing nations only consisted of three countries from Asia, a more thorough study would include several developing nations from South America, Africa, and Europe. We could perhaps see a trend occurring in these countries that governments alone might actually be pushing out FDI, and may be in need of an interaction variable to attract FDI, such as our interaction variable of FDI and GDP. If this trend persists, we can imply that developing nations do need a combination of strong governments that can adopt effective economic policies to improve the living 
standards of its people in order to attract FDI. In addition, this could also prove to be vital as a government policy in which any developing nation can adopt.

Another interesting point to make about extending our study is to include other developing nations within Asia. We have chosen three of the most economical successful countries in Asia, so it would be worthwhile to include other developing nations that are considered not as successful and unsuccessful, such as the Philippines, Thailand and Vietnam, and Cambodia, Laos and Myanmar, respectively. We do see many strong governments, primarily that of the Philippines as its governmental system emulates that of the U.S, but its challenge is to convince international investors that their investments are not only safe, but can yield high returns. This is the main issue why the Philippines finds itself behind most developing Asian nations as it does not have the type of economic appeal in the international community, not to mention its own domestic issues of political turmoil in Mindanao and high levels of corruption. Moreover, it would be interesting to see the analyses for a country like Myanmar.

The United Nations still considers this plagued country by its rightful name of Burma, regardless of the military junta that governs the country. However, here is one case where we know the rule of law is stringent, so we can assume that its RPC is greater than one, but has a very difficult time in attracting FDI. We do not really here much nowadays about international investors flocking to Myanmar to invest their capital, hence we could expect to see this government turned around by adopting effective economic policies of improving its living standards, thus the need for an interaction variable.

It would also be interesting to compare and contrast our results by adding an additional component of religion. We can see that China is considered as a non-religious country, while India and Indonesia are highly religious. We can analyze the effects of 
international investors and their preferences to invest in a country where no religion exists, or more specifically, a Hindu or Islamic country. This could shed light to how religion plays a role in a government's ability to attract FDI. There are a few claims that a developing country with no religion has the advantage of a strictly business only mentality, thus reducing the transaction costs of patronage to religious leaders and/or the infrastructure build-up on sacred land. However, the counter arguments to this is that religion can attract FDI as more investors might be more inclined to invest in a developing country where it shares the same belief and value system. We can also see the percentage of Hindus and Muslims around the world at $14 \%$ and $21 \%$, respectively, versus non-religious individuals at $16 \%$, so the likelihood of an international investor having a religion is much higher than no religion at all.

One more point to make on the additional variable of religion. It would be interesting to see whether if the type of religion plays a factor in a government's ability to attract FDI. We mentioned the percentage of individuals worldwide who considers themselves as Hindu or Muslim, but analyzing the perception of either of these religions in attracting FDI would be interesting. Political events, such as September 11, 2001 has tarnished the good name of Islam worldwide as many people unfortunately associate 'terrorism' with Islam, so determining whether or not the type of religion plays a role in attracting FDI would be beneficial for the economic growth literature and developing countries altogether.

Lastly, to further extend our analyses and findings, it would also be interesting to include another variable of 'terrorist attack.' Unlike China, both India and Indonesia due to its democratic style of governing has been victims of terrorist attacks in the 2008 Mumbai Attacks and 2002 and 2005 Bali Bombings. We have not yet experienced any 
terrorist attacks in China, and perhaps due to its strict authoritarian rule over its borders, but this could also play a role to international investors as they may feel more safe and comfortable investing in a developing country that is not plagued by terrorist attacks. Overall, there are a lot of additional items we would like to include to strengthen this research in order to better understand a provincial government's ability to effectively attract FDI in its country. Nevertheless, we have started a very interesting research in the sub-national level literature, and can only improve the literature with future studies. 


\section{REFERENCE PAGE}

Acemoglu, D., S. Johnson, and J. Robinson, (2005). "Institutions as the

Fundamental Cause of Long-run Growth," NBER wp 10481, Handbook of Economic Growth, North-Holland. Elsevier.

Acemoglu, Daron; Johnson, Simon; Robinson, James A. and Thaicharoen, Yunyong (2002). "Reversal of Fortune: Geography and Institutions in the Making of the Modern World Income Distribution." Quarterly Journal of Economics, pp 117.

Alcazar, Lorena (1997). Political Capacity and the Use of Seigniorage. In Marina Arbetman and Jacek Kugler (Eds.). Political Capacity and Economic Behavior. Boulder: Westview Press.

American Civil Liberties Union. Retrieved from http://aclu.org.

Ang, James B. (2008). Determinants of Foreign Direct Investment in Malaysia. Journal of Policy Modeling. New York: Jan/Feb 2008. Vol. 30, Issue 1; pp. 185.

Ang, James B (2008). "Finance And Inequality: The Case Of India," CAMA Working Papers 2008-18, Australian National University, Centre for Applied Macroeconomic Analysis.

Arbetman, M. and J. Kugler (1997). Political Capacity and Economic Behavior. Boulder, CO: Westview Press.

Balasubramanyam, V.N, M. Salisu and David Sapsford (1996). Foreign Direct Investment and Growth in EP. The Economic Journal. Vol. 106, pp. 92105.

Banga, R. (2003). The Differential Impact of Japanese and U.S. Foreign Direct Investments on Exports of Indian Manufacturing. Indian Council for Research on International Economic Relations, New Delhi. (http://econpapers.repec.org/RAS/pba255.htm).

Bhagwati, Jagdish (1987). "Quid Pro Quo DFI and VIEs: PoliticalEconomy-Theoretic Analyses," International Economic Journal 1, pp. 1-14.

Black's Law Dictionary: Fifth Edition. (1979).

Borensztien, E., De Gregorio, J. and J-W. Lee (1998). How Does Foreign Direct Investment Affect Growth? Journal of International Economics. Vol. 45, pp. 115-135. 
Cerdenia, Grace C (2001). Ticker Talk. Business World. Manila.

Chowdhury, Abdur and George Mavrotas (2006). FDI and GDP: What Causes What? The World Economy. Vol. 9 No. 1 pp 9-19.

De Soto, H. (2000). The Mystery of Capital: Why Capitalism Triumphs in the West and Fails Everywhere Else. New York: Basic Books.

Dunning, J. H. (1999). Multinational Enterprises and the Growth of Services: Some Conceptual and Theoretical Issues. The Service Industry Journal, Vol. 9, pp, 5-39.

Enderwick, P (1989). Policy Issues in International Trade and Investment Services. Multinational Service Firms (pp. 215-244). New York: Routledge.

Feng, Yi. (2003). Democracy, Governance, and Economic Performance: Theory and Evidence. Cambridge: The MIT Press.

Feng, Yi, and et. al. (2008). Path to Prosperity: The Dynamics of Freedom and Economic Development. International Interactions. London: Routledge.

Foley, C. F, and Mihir A. D., and Hines Jr, J.R. (2004). A Multinational Perspective on Capital Structure Choice and Internal Capital Markets. Journal of Finance, Vol.59, No. 6, pp. 2451-2488.

Gwartney, J., and Lawson, R., S, S. R., and Leeson, P. T. (2007). Economic Freedom of the World: 2007 Annual Report. Vancouver, BC: The Fraser Institute.

Hanson, Gordon H. (2005). Globalization, Labor Income, and Poverty in Mexico. NBER Working Paper No. 11027.

Harms, Philipp and Heinrich W. Ursprung (2002). Do Civil and Political Repression Really Boost Foreign Direct Investments? Economic Inquiry. Oxford University:Vol. 40, pp. 651.

Hayek, Friedrich (1961). The Constitution of Liberty. New York: University of Chicago Press.

Joel Hellman et al. (2000). Are Foreign Investors and Multinationals Engaging in Corrupt Practices in Transition Economies? Transition, The World Bank/The William Davidson Institute/Stockholm Institute for Transition Economies. 
Hufbauer G.C. and Schott, J.J. (2005). NAFTA Revisited, Institute for International Economics, Washington D.C. International Economic Development Council. Retrieved from http://iedc.org.

International Monetary Fund. Retrieved from http://imf.org.

Johnson, Kristin (2007). Sub National Capabilities and Internal Conflict. PhD Dissertation, Claremont Graduate University.

Kane, Tim, and Kim R. Holmes and Mary Anastasia O'Grady (2007). 2007

Index of Economic Freedom. The Wall Street Journal. Heritage Foundation, Massachusetts.

Kaufmann, Daniel, et. al (2008). Governance Matters VII: Aggregate and Individual Governance Indicators, 1996-2007. World Bank Policy Research Working Paper No. 4654.

Konan, D.E and Maskus, K.E (2004). Quantifying the Impact of Services Liberalisation in a Developing Country, World Bank Policy Research Paper 3193 Washington D.C.: World Bank.

Krueger, Anne O. (1974). "The Political Economy of the Rent Seeking Society," American Economic Review, Vol. 64, pp. 291-303.

Leecraw, D.J. (1977). Direct Investments by Firms from Less Developed Countries. Oxford Economic Papers, 29, 442-457.

Lezard, Ashleigh (2002). Rising from the Ashes. Financial Times Business.

Lundstrom, S. (2005). The Effect of Democracy on Different Categories of Economic Freedom. European Journal of Political Economy, Vol. 21, pp. 967980.

Mankiw, Gregory, and David Romer and David Weil (1992). A Contribution to the Empirics of Economic Growth. The Quarterly Journal of Economics.

Markusen, James R (2000). Foreign Direct Investment. Working Paper No. 19 from the Social Science Research Network.

Moran, Theordore H., \& Graham E M., \& Blomström, M. (2005). Does Foreign Direct Investment Promote Development? Peterson Institute.

Organization for Economic Cooperation and Development. Retrieved from www.oecd.org/home/0,2987,en_2649_201185_1_1_1_1_1,00.html. 
Pamacheche, Fudzai, and Baboucarr Koma (2007). Privatization in SubSaharan Africa. African Integration Review. Vol. 1, 2. Political Instability Task Force. Retrieved from http://globalpolicy.gmu.edu/pitf/

Ross, Michael (1999). The Political Economy of the Resource Curse. World Politics, Vol. 5, pp. 297-322.

Sachs, Jeffrey D. \& Warner, Andrew M. (2001). The Curse of Natural Resources. European Economic Review. Elsevier, Vol. 45(4-6), pp. 827-838.

Schneider, F. and B. Frey (1985). Economic and Political Determinants of Foreign Direct Investment. World Development, Vol. 13, pp. 161-175.

Singer, H.W. 1950. U.S. Foreign Investment in Underdeveloped Areas: The Distribution of Gains Between Investing and Borrowing Countries. American Economic Review, Papers and Proceedings Vol. 40, pp. 473-485.

Snyder, Jack (2000). From Voting to Violence: Democratization and Nationalist Conflict. New York: W.W. Norton.

Suellentrop, Chris (2004). America's New Political Capital. Slate.

The World Bank. (2005). World Development Report 2005: A Better Investment Climate for Everyone. The World Bank Publications.

Transparency International. Retrieved from http://transparency.org.

United Nations. Retrieved from http://un.org.

U.S. Department of Commerce. Retrieved from http://www.bea.gov/.

Vos, R., Taylor, L., Paes de Barros, R. (2002). Economic Liberalization, Distribution and Poverty. Latin America in the 1990's, Edward Elgar Publishing Ltd., Cheltenham.

Wells, L. T., Jr. (1981). Foreign Investors from the Third World. Multinationals from Developing Countries. Washington, DC: Health. 


\section{APPENDIX A}

List of Provinces by Country, 1994-2000

\begin{tabular}{|l|l|l|}
\hline China & India & Indonesia \\
1. Beijing & 1. Andhra Pradesh & 1. Di Aceh \\
2. Tianjin & 2. Arunachal Pradesh & 2. Sumater Utara \\
3. Hebei & 3. Assam & 3. Sumatera Barat \\
4. Shanxi & 4. Bihar & 4. Riau \\
5. Inner Mongolia & 5. Goa & 5. Jambi \\
6. Liaoning & 6. Gujarat & 6. Sumatera Selatan \\
7. Jilin & 7. Haryana & 7. Bangka Belitung \\
8. Heilongjiang & 8. Himachal Pradesh & 8. Bengkulu \\
9. Shanghai & 9. Jammu \& Kashmir & 9. Lampung \\
10. Jiangsu & 10. Karnataka & 10. Banten \\
11. Zhejiang & 11. Kerala & 11. Dki Jakarta \\
12. Anhui & 12. Madhya Pradesh & 12. Jawa Barat \\
13. Fujian & 13. Maharashtra & 13. Jawa Tengah \\
14. Jiangxi & 14. Manipur & 14. Di Jogyakarta \\
15. Shandong & 16. Mizoram & 15. Jawa Timur \\
16. Henan & 17. Nagaland & 16. Bali \\
17. Hubei & 18. Orissa & 17. Nusatenggara Barat \\
18. Hunan & 19. Punjab & 19. Timor Timur \\
19. Guangdong & 20. Rajasthan & 20. Kalimantan Barat \\
20. Guangxi & 21. Sikkim & 21. Kalimantan Tengah \\
21. Hainan & 22. Tamil Nadu & 22. Kalimantan Selatan \\
22. Chongqing & 23. Tripura & 23. Kalimantan Timur \\
23. Sichuan & 24. Uttar Pradesh & 24. Sulawesi \\
24. Guizhou & 25. West Bengal & Gorontalo \\
25. Yunnan & 26. Chattisgarh & 25. Sulawesi Tengah \\
26. Tibet & 27. Uttaranchal & 26. Sulawesi Selatan \\
27. Shanxi & 28. Delhi & 27. Sulawesi Tenggara \\
28. Gansu & 29. Pondicherry & Maluku \\
29. Qinghai & 30. Daman \& Diu & 28. Maluku \\
30. Ningxia & & 29. Irian Jaya \\
& & \\
\hline
\end{tabular}

\section{APPENDIX B}

Open Economy Issue Continuum 
Low GDP and Low FDI

$<10$ billion and $<10$ million

25

Partially Open

Low-Medium GDP Low-

Medium FDI

10-20 billion and 11-25

million

50

Midway Open

Medium GDP Medium FDI

21-40 billion and 26-50

million

75

Opening Economy

Medium-High GDP Medium-

High FDI

41-60 billion and 51-100

million

100

Open Economy

High GDP High FDI

60 billion and $>100$ million

\section{APPENDIX C}

Summary Statistics

\begin{tabular}{llllll}
\hline Variable & Observations & Minimum & Maximum & Mean & Std. deviation \\
\hline FDI & 489 & 7.850 & 1202166.900 & 60699.907 & 161234.247
\end{tabular}




\begin{tabular}{llllll} 
GDP & 489 & 149071.500 & 162740958.800 & 18949572.990 & 25405273.966 \\
GDP*RPC & 489 & 79824.980 & 179212888.450 & 17382080.522 & 21604627.787 \\
Democracy & 489 & 0.000 & 1.000 & 0.587 & 0.493 \\
$\begin{array}{l}\text { Open } \\
\text { Economy }\end{array}$ & 489 & 1.000 & 100.000 & 29.575 & 34.785 \\
\hline
\end{tabular}

\section{APPENDIX D}

List of Countries and Variables: FDI, RPC, GDP, RPC*GDP, Democracy, and Open Economy 
- regress FDI RPC GDP RPCGDP Dem Open

\begin{tabular}{|c|c|c|c|c|c|c|c|}
\hline Source & SS & $d f$ & \multicolumn{2}{|c|}{ MS } & & \multirow{3}{*}{$\begin{array}{l}\text { Number of obs } \\
\text { F( } 5, \quad 484) \\
\text { Prob }>\quad F \\
\text { R-squared } \\
\text { Adj R-squared } \\
\text { Root MSE }\end{array}$} & \multirow{3}{*}{$\begin{array}{rr}= & 490 \\
= & 122.50 \\
= & 0.0000 \\
= & 0.5586 \\
= & 0.5540 \\
= & 107.59\end{array}$} \\
\hline $\begin{array}{r}\text { Mode1 } \\
\text { Residua1 }\end{array}$ & $\begin{array}{r}7090312.95 \\
5602970.5\end{array}$ & $\begin{array}{r}5 \\
484\end{array}$ & $\begin{array}{l}141 \\
115\end{array}$ & $\begin{array}{l}62.59 \\
.3853\end{array}$ & & & \\
\hline Total & 12693283.4 & 489 & 259 & .6349 & & & \\
\hline FDI & coef. & std. & Err. & $t$ & $P>|t|$ & [95\% Conf. & Interva1] \\
\hline $\begin{array}{r}\text { RPC } \\
\text { GDP } \\
\text { RPCGDP } \\
\text { Dem } \\
\text { Open } \\
\text { cons }\end{array}$ & $\begin{array}{r}-3.179844 \\
34.64317 \\
13.83407 \\
44.2538 \\
.5731089 \\
-68.46979\end{array}$ & $\begin{array}{l}12.6 \\
7.792 \\
8.687 \\
15.02 \\
.2915 \\
19.4\end{array}$ & $\begin{array}{l}194 \\
103 \\
737 \\
325 \\
571 \\
352\end{array}$ & $\begin{array}{r}-0.25 \\
4.45 \\
1.59 \\
2.95 \\
1.97 \\
-3.52\end{array}$ & $\begin{array}{l}0.801 \\
0.000 \\
0.112 \\
0.003 \\
0.050 \\
0.000\end{array}$ & $\begin{array}{r}-27.97542 \\
19.33264 \\
-3.236266 \\
14.73494 \\
.000235 \\
-106.6576\end{array}$ & $\begin{array}{r}21.61573 \\
49.9537 \\
30.90441 \\
73.77265 \\
1.145983 \\
-30.282\end{array}$ \\
\hline
\end{tabular}

\section{APPENDIX E}

Correlation Matrix for All Countries 


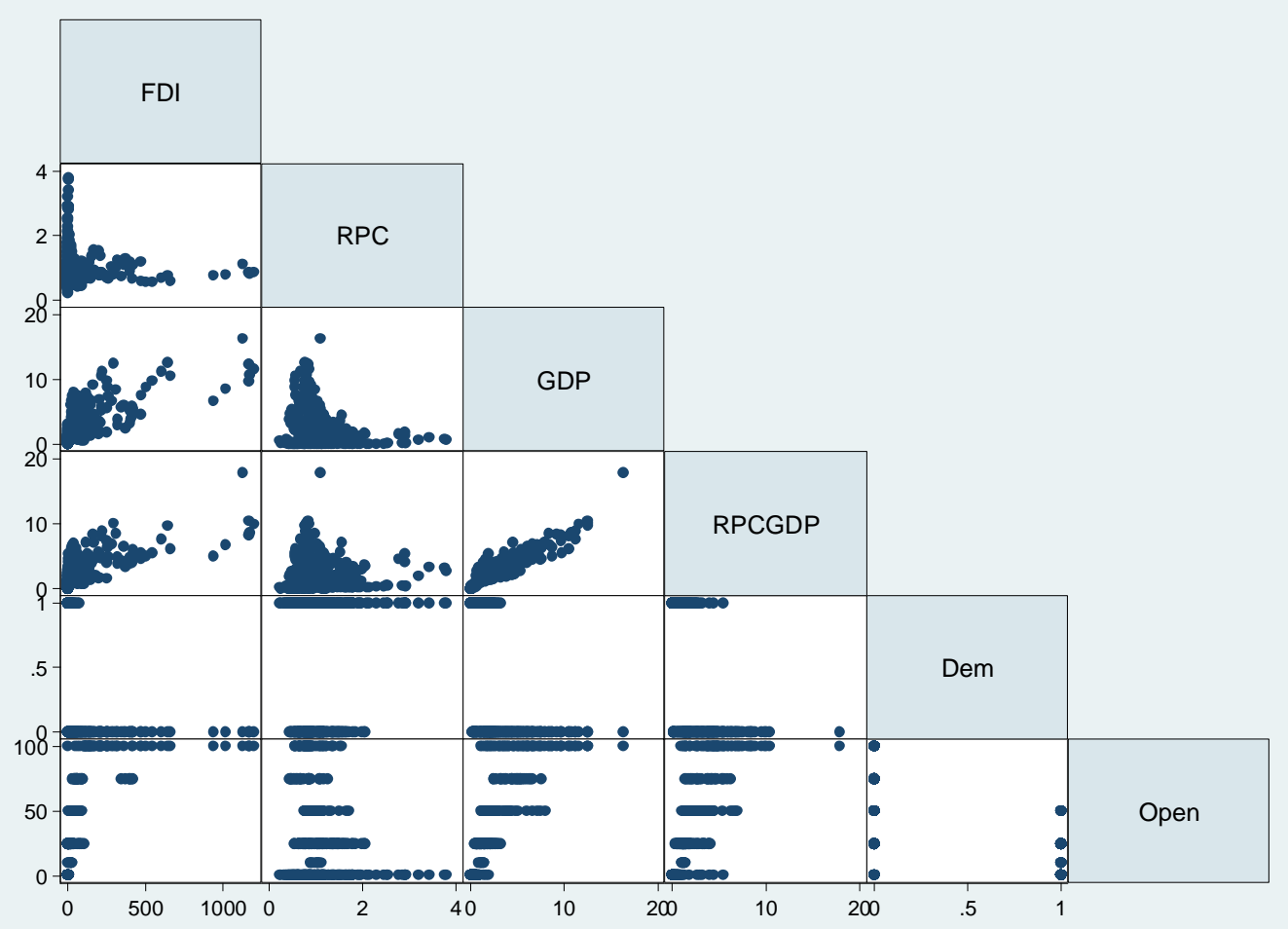

APPENDIX F 
List of Countries and Variables: FDI, RPC*GDP, Democracy, and Open Economy

- regress FDI RPCGDP Dem Open

\begin{tabular}{|c|c|c|c|c|c|c|c|}
\hline Source & ss & $d f$ & \multicolumn{2}{|c|}{ MS } & & \multirow{3}{*}{$\begin{array}{l}\text { Number of obs } \\
\text { F( } 3,486) \\
\text { Prob }>F \\
\text { R-squared } \\
\text { Adj R-squared } \\
\text { Root MSE }\end{array}$} & \multirow{3}{*}{$\begin{array}{lr}= & 490 \\
= & 183.80 \\
= & 0.0000 \\
= & 0.5315 \\
= & 0.5286 \\
= & 110.62\end{array}$} \\
\hline $\begin{array}{r}\text { Mode1 } \\
\text { Residua1 }\end{array}$ & $\begin{array}{l}6746737.04 \\
5946546.41\end{array}$ & $\begin{array}{r}3 \\
486\end{array}$ & $\begin{array}{l}224 \\
122\end{array}$ & $\begin{array}{l}12.35 \\
.6922\end{array}$ & & & \\
\hline Tota1 & 12693283.4 & 489 & 259 & .6349 & & & \\
\hline FDI & Coef. & std. & Err. & $\mathrm{t}$ & $P>|t|$ & [95\% conf. & Interval] \\
\hline $\begin{array}{r}\text { RPCGDP } \\
\text { Dem } \\
\text { Open } \\
\text { _cons }\end{array}$ & $\begin{array}{r}45.45263 \\
53.07678 \\
1.217187 \\
-85.41803\end{array}$ & $\begin{array}{l}3.78 \\
15.3 \\
.273 \\
15.3\end{array}$ & $\begin{array}{l}264 \\
617 \\
233 \\
139\end{array}$ & $\begin{array}{r}12.01 \\
3.47 \\
4.45 \\
-5.55\end{array}$ & $\begin{array}{l}0.000 \\
0.001 \\
0.000 \\
0.000\end{array}$ & $\begin{array}{r}38.01709 \\
22.9827 \\
-6791635 \\
-115.6599\end{array}$ & $\begin{array}{r}52.88817 \\
83.17087 \\
1.755211 \\
-55.17614\end{array}$ \\
\hline
\end{tabular}

\section{APPENDIX G}


List of Countries and Variables: FDI, RPC*GDP, Democracy, and Open Economy with

Beta Coefficients

\begin{tabular}{|c|c|c|c|c|c|c|c|}
\hline Source & ss & $d f$ & \multicolumn{2}{|r|}{ MS } & & \multirow{3}{*}{$\begin{array}{l}\text { Number of obs } \\
\text { F( } 3,486) \\
\text { Prob }>\text { F } \\
\text { R-squared } \\
\text { Adj R-squared } \\
\text { Root MSE }\end{array}$} & \multirow{3}{*}{$\begin{array}{lr}= & 490 \\
= & 183.80 \\
= & 0.0000 \\
= & 0.5315 \\
= & 0.5286 \\
= & 110.62\end{array}$} \\
\hline $\begin{array}{r}\text { Model } \\
\text { Residual }\end{array}$ & $\begin{array}{l}6746737.04 \\
5946546.41\end{array}$ & $\begin{array}{r}3 \\
486\end{array}$ & \multicolumn{2}{|c|}{$\begin{array}{l}2248912.35 \\
12235.6922\end{array}$} & & & \\
\hline Total & 12693283.4 & 489 & \multicolumn{2}{|c|}{25957.6349} & & & \\
\hline FDI & coef. & Std. & Err. & $t$ & $P>|t|$ & & Beta \\
\hline $\begin{array}{r}\text { RPCGDP } \\
\text { Dem } \\
\text { open } \\
\text { _cons }\end{array}$ & $\begin{array}{r}45.45263 \\
53.07678 \\
1.217187 \\
-85.41803\end{array}$ & $\begin{array}{l}3.784 \\
15.31 \\
.2738 \\
15.39\end{array}$ & $\begin{array}{l}4264 \\
1617 \\
8233 \\
9139\end{array}$ & $\begin{array}{r}12.01 \\
3.47 \\
4.45 \\
-5.55\end{array}$ & $\begin{array}{l}0.000 \\
0.001 \\
0.000 \\
0.000\end{array}$ & & $\begin{array}{l}.6088342 \\
.1624458 \\
.2636274\end{array}$ \\
\hline
\end{tabular}

\section{APPENDIX H}


List of Countries and Variables: FDI, RPC*GDP, Democracy, and Open Economy with

BP Test and Robust Standard Errors

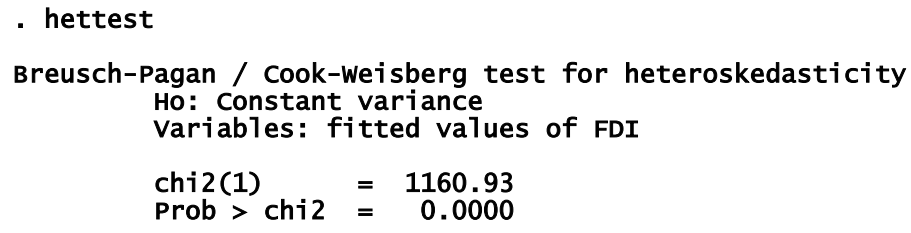

\begin{tabular}{r|rlrrrr}
\hline \multirow{2}{*}{ FDI } & Coef. & Robust \\
& Std. Err. & $t$ & $\mathrm{P}>|\mathrm{t}|$ & [95\% Conf. Interva]] \\
\hline RPCGDP & 45.45263 & 9.295288 & 4.89 & 0.000 & 27.18871 & 63.71654 \\
Dem & 53.07678 & 13.09901 & 4.05 & 0.000 & 27.33909 & 78.81447 \\
Open & 1.217187 & .3322728 & 3.66 & 0.000 & .5643185 & 1.870056 \\
_Cons & -85.41803 & 16.11135 & -5.30 & 0.000 & -117.0745 & -53.76153
\end{tabular}

\section{APPENDIX I}


List of Countries and Variables: FDI, RPC*GDP, Democracy, and Open Economy with

VIF Test and Independence Test

- vif

\begin{tabular}{r|rr} 
Variable & VIF & $1 /$ VIF \\
\hline Open & 3.65 & 0.274061 \\
RPCGDP & 2.67 & 0.375156 \\
Dem & 2.28 & 0.438679 \\
\hline Mean VIF & 2.86 &
\end{tabular}

. Tinktest

\begin{tabular}{|c|c|c|c|c|c|c|c|}
\hline Source & SS & $d f$ & \multicolumn{2}{|c|}{ MS } & & \multirow{3}{*}{$\begin{array}{l}\text { Number of obs } \\
\text { F( } 2,487) \\
\text { Prob > F } \\
\text { R-squared } \\
\text { Adj R-squared } \\
\text { Root MSE }\end{array}$} & \multirow{3}{*}{$\begin{array}{rr}= & 490 \\
= & 361.83 \\
= & 0.0000 \\
= & 0.5977 \\
= & 0.5961 \\
= & 102.39\end{array}$} \\
\hline $\begin{array}{r}\text { Mode1 } \\
\text { Residua1 }\end{array}$ & $\begin{array}{l}7587288.21 \\
5105995.23\end{array}$ & $\begin{array}{r}2 \\
487\end{array}$ & $\begin{array}{l}379 \\
104\end{array}$ & .11 & & & \\
\hline Total & 12693283.4 & 489 & 259 & 6349 & & & \\
\hline FDI & coef. & Std. & Err. & $\mathrm{t}$ & $P>|t|$ & [95\% Conf. & Interva1] \\
\hline $\begin{array}{r}\text { _hat } \\
\text { _hatsq } \\
\text { _cons }\end{array}$ & $\begin{array}{r}.4645922 \\
.0015591 \\
5.34683\end{array}$ & $\begin{array}{l}.0716 \\
.0001 \\
5.245\end{array}$ & $\begin{array}{l}218 \\
741 \\
167\end{array}$ & $\begin{array}{l}6.49 \\
8.95 \\
1.02\end{array}$ & $\begin{array}{l}0.000 \\
0.000 \\
0.309\end{array}$ & $\begin{array}{r}.3238662 \\
.001217 \\
-4.959122\end{array}$ & $\begin{array}{r}.6053182 \\
.0019012 \\
15.65278\end{array}$ \\
\hline
\end{tabular}

\section{APPENDIX J}


List of Chinese Provinces and Variables: FDI, RPC, GDP, RPC*GDP, Democracy, and

\section{Open Economy}

- reg FDI RPC GDP RPCGDP Open

\begin{tabular}{r|crc} 
Source & SS & df & MS \\
\hline $\begin{array}{r}\text { Mode1 } \\
\text { Residua1 }\end{array}$ & 5244633.68 & 4 & 1311158.42 \\
\hline Total & 10463908.6 & 202 & 51801.5277
\end{tabular}

Number of obs $=203$

$F(4,198)=49.74$

Prob $>\mathrm{F}=0.0000$

R-squared $=0.5012$

Adj R-squared $=0.4911$

\begin{tabular}{l|lll} 
Total & 10463908.6 & 202 & 51801.5277
\end{tabular}

Root MSE $=162.36$

\begin{tabular}{r|rlrrrr}
\hline FDI & Coef. & std. Err. & $\mathrm{t}$ & $\mathrm{P}>|\mathrm{t}|$ & \multicolumn{2}{c}{ [95\% Conf. Interva1] } \\
\hline RPC & $\mathbf{8 . 5 6 2 7 7}$ & 63.43543 & 0.13 & 0.893 & -116.533 & 133.6586 \\
GDP & 28.508 & 17.66764 & 1.61 & 0.108 & -6.332896 & 63.3489 \\
RPCGDP & 22.03393 & 20.04665 & 1.10 & 0.273 & -17.4984 & 61.56627 \\
Open & 1.069654 & -4916123 & 2.18 & 0.031 & .100186 & 2.039122 \\
_Cons & -114.1801 & 68.87145 & -1.66 & 0.099 & -249.9958 & 21.63562 \\
\hline
\end{tabular}

\section{APPENDIX K}


Correlation Matrix for Chinese Provincial Governments

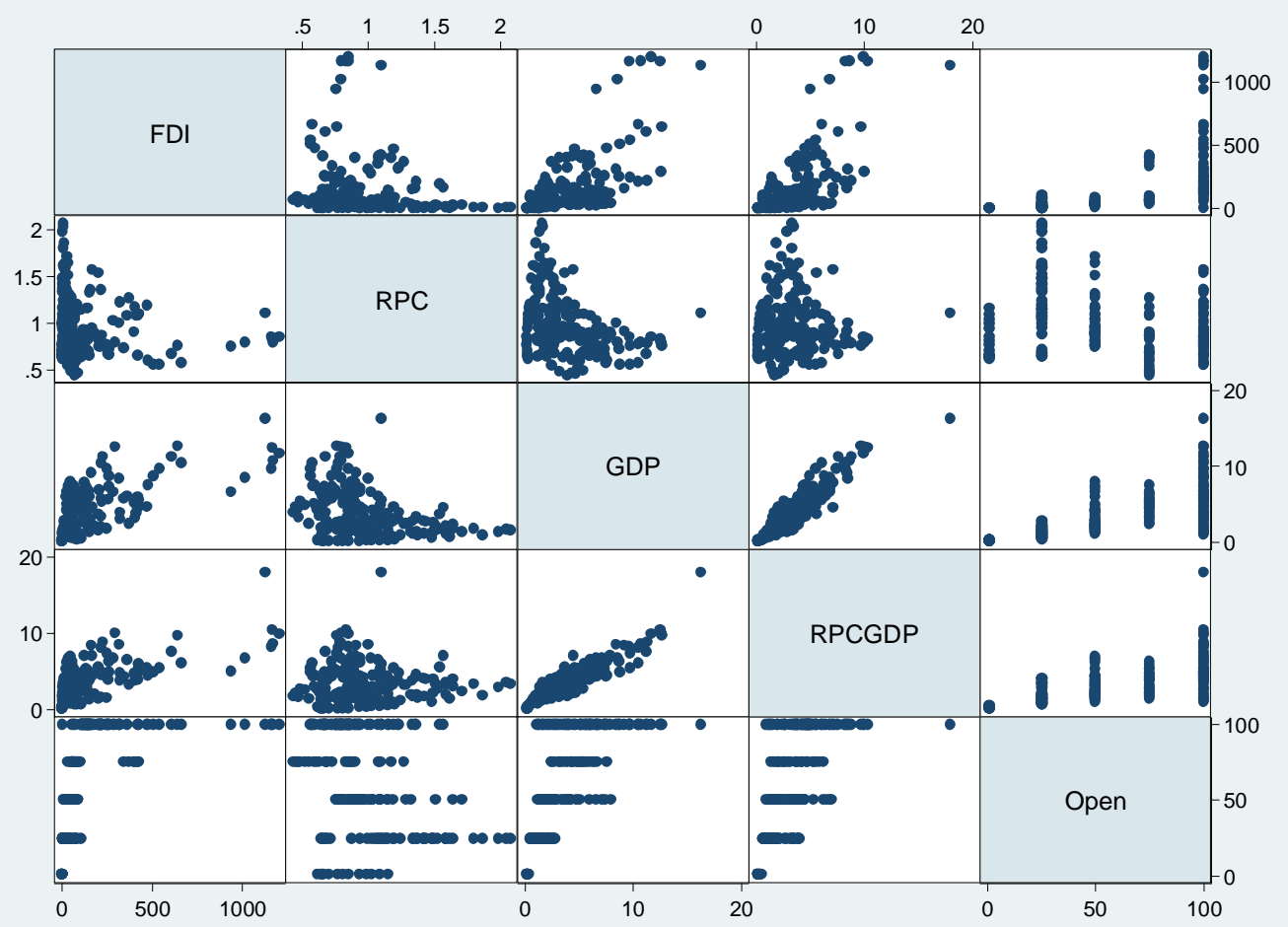


List of Chinese Provinces and Variables: FDI, RPC*GDP, Democracy, and

\section{Open Economy}

\begin{tabular}{|c|c|c|c|c|c|c|c|}
\hline Source & ss & $d f$ & \multicolumn{2}{|c|}{ MS } & & \multirow{3}{*}{$\begin{array}{l}\text { Number of obs } \\
F(2, \quad 200) \\
\text { Prob }>\text { F } \\
\text { R-squared } \\
\text { Adj R-squared } \\
\text { Root MSE }\end{array}$} & \multirow{3}{*}{$\begin{array}{rr}= & 203 \\
= & 94.77 \\
= & 0.0000 \\
= & 0.4866 \\
= & 0.4814 \\
= & 163.9\end{array}$} \\
\hline $\begin{array}{r}\text { Mode1 } \\
\text { Residua1 }\end{array}$ & $\begin{array}{l}5091557.84 \\
5372350.76\end{array}$ & $\begin{array}{r}2 \\
200\end{array}$ & $\begin{array}{l}2545 \\
2686\end{array}$ & $\begin{array}{l}8.92 \\
7538\end{array}$ & & & \\
\hline Total & 10463908.6 & 202 & 5180 & .5277 & & & \\
\hline FDI & coef. & std. & Err. & $t$ & $P>|t|$ & [95\% Conf. & Interval] \\
\hline $\begin{array}{r}\text { RPCGDP } \\
\text { Open } \\
\text { _cons }\end{array}$ & $\begin{array}{r}50.31244 \\
1.527802 \\
-120.5288\end{array}$ & $\begin{array}{l}6.031 \\
.452 \\
24.55\end{array}$ & $\begin{array}{l}247 \\
441 \\
994\end{array}$ & $\begin{array}{r}8.34 \\
3.38 \\
-4.91\end{array}$ & $\begin{array}{l}0.000 \\
0.001 \\
0.000\end{array}$ & $\begin{array}{r}38.41945 \\
-6356352 \\
-168.9585\end{array}$ & $\begin{array}{r}62.20543 \\
2.419968 \\
-72.09917\end{array}$ \\
\hline
\end{tabular}

\section{APPENDIX M}


List of Chinese Provinces and Variables: FDI, RPC*GDP, Democracy, and Open

Economy with Beta Coefficients

- reg FDI RPCGDP Open, b

\begin{tabular}{r|crc} 
Source & SS & df & MS \\
\hline Model & 5091557.84 & 2 & 2545778.92 \\
Residual & 5372350.76 & 200 & 26861.7538 \\
\hline Total & 10463908.6 & 202 & 51801.5277
\end{tabular}

\begin{tabular}{l|lll} 
Total & 10463908.6 & 202 & 51801.5277
\end{tabular}

\begin{tabular}{r|rlccr}
\hline FDI & Coef. & Std. Err. & t & P>|t| & Beta \\
\hline RPCGDP & 50.31244 & 6.031247 & 8.34 & 0.000 & .5401194 \\
Open & 1.527802 & .452441 & 3.38 & 0.001 & .2186385 \\
-Cons & -120.5288 & 24.55994 & -4.91 & 0.000 &. \\
\hline
\end{tabular}

\section{APPENDIX N}


List of Chinese Provinces and Variables: FDI, RPC*GDP, Democracy, and Open

Economy with BP Test and Robust Standard Errors

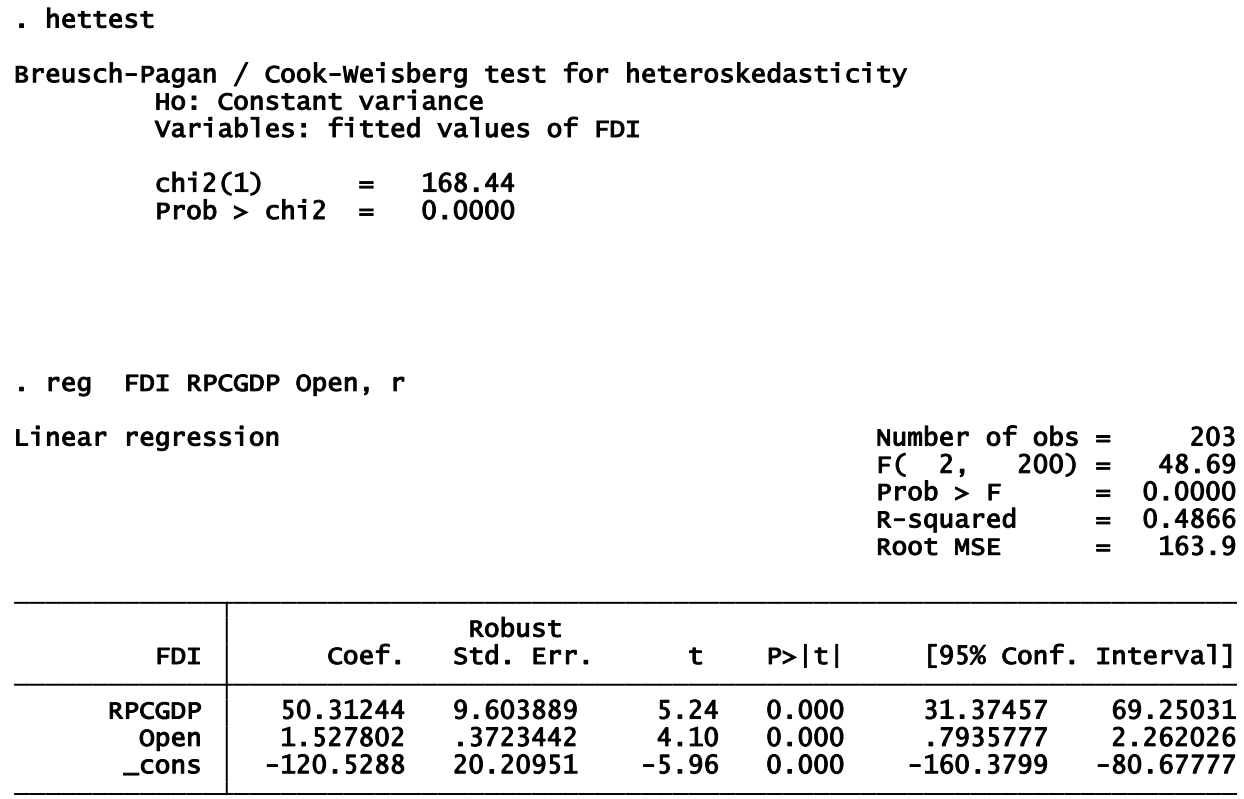

\section{APPENDIX O}


List of Chinese Provinces and Variables: FDI, RPC*GDP, Democracy, and Open

Economy with VIF Test and Independence Test

- vif

\begin{tabular}{r|rr} 
Variable & VIF & $1 /$ VIF \\
\hline Open & 1.63 & 0.612347 \\
RPCGDP & 1.63 & 0.612347 \\
\hline Mean VIF & 1.63 &
\end{tabular}

. Tinktest

\begin{tabular}{|c|c|c|c|c|c|c|c|}
\hline Source & ss & $d f$ & \multicolumn{2}{|c|}{ MS } & & \multirow{3}{*}{$\begin{array}{l}\text { Number of obs } \\
\text { F( 2, 200) } \\
\text { Prob > F } \\
\text { R-squared } \\
\text { Adj R-squared } \\
\text { Root MSE }\end{array}$} & \multirow{3}{*}{$\begin{array}{rr}= & 203 \\
= & 115.76 \\
= & 0.0000 \\
= & 0.5365 \\
= & 0.5319 \\
= & 155.72\end{array}$} \\
\hline $\begin{array}{r}\text { Mode1 } \\
\text { Residual }\end{array}$ & $\begin{array}{l}5614207.77 \\
4849700.83\end{array}$ & $\begin{array}{r}2 \\
200\end{array}$ & $\begin{array}{l}2807 \\
2424\end{array}$ & $\begin{array}{l}88 \\
42\end{array}$ & & & \\
\hline Total & 10463908.6 & 202 & 5180 & 5277 & & & \\
\hline FDI & Coef. & Std. & Err. & $t$ & $P>|t|$ & [95\% Conf. & $\overline{\text { Interval] }}$ \\
\hline $\begin{array}{r}\text { _hat } \\
\text { _hatsq } \\
\text { _cons }\end{array}$ & $\begin{array}{r}5174793 \\
.001108 \\
18.14626\end{array}$ & $\begin{array}{l}.124 \\
.000 \\
15.1\end{array}$ & $\begin{array}{l}579 \\
386 \\
752\end{array}$ & $\begin{array}{l}4.15 \\
4.64 \\
1.20\end{array}$ & $\begin{array}{l}0.000 \\
0.000 \\
0.232\end{array}$ & $\begin{array}{r}.2714697 \\
-0006374 \\
-11.68365\end{array}$ & $\begin{array}{r}.763489 \\
.0015786 \\
47.97617\end{array}$ \\
\hline
\end{tabular}

\section{APPENDIX P}


List of Indian Provinces and Variables: FDI, RPC, GDP, RPC*GDP, Democracy, and

\section{Open Economy}

- reg FDI RPC GDP RPCGDP Open

\begin{tabular}{r|crc} 
Source & SS & df & MS \\
\hline $\begin{array}{r}\text { Mode1 } \\
\text { Residua1 }\end{array}$ & 9491.19263 & 4 & 2372.79816 \\
\hline Tota1 & 20966.6564 & 104 & 201.602465
\end{tabular}

Number of obs $=105$

$F(4,100)=20.68$

Prob $>\mathrm{F}=0.0000$

R-squared $=0.4527$

Adj $R$-squared $=0.4308$

\begin{tabular}{l|lll} 
Total & 20966.6564 & 104 & 201.602465
\end{tabular}

Root MSE $=10.712$

\begin{tabular}{r|rlrrrr}
\hline FDI & Coef. & std. Err. & $\mathrm{t}$ & $\mathrm{P}>|\mathrm{t}|$ & \multicolumn{2}{c}{ [95\% Conf. Interva1] } \\
\hline RPC & -1.730007 & 7.105118 & -0.24 & 0.808 & -15.82636 & 12.36634 \\
GDP & -10.25492 & 6.302628 & -1.63 & 0.107 & -22.75915 & 2.249316 \\
RPCGDP & 14.64116 & 7.531773 & 1.94 & 0.055 & -.3016679 & 29.58398 \\
Open & -4493911 & $\mathbf{1 1 2 6 1 8 5}$ & 3.99 & 0.000 & -2259591 & .6728231 \\
_COns & 2.097693 & 7.924111 & 0.26 & 0.792 & -13.62352 & 17.8189 \\
\hline
\end{tabular}

\section{APPENDIX Q}


Correlation Matrix for Indian Provincial Governments

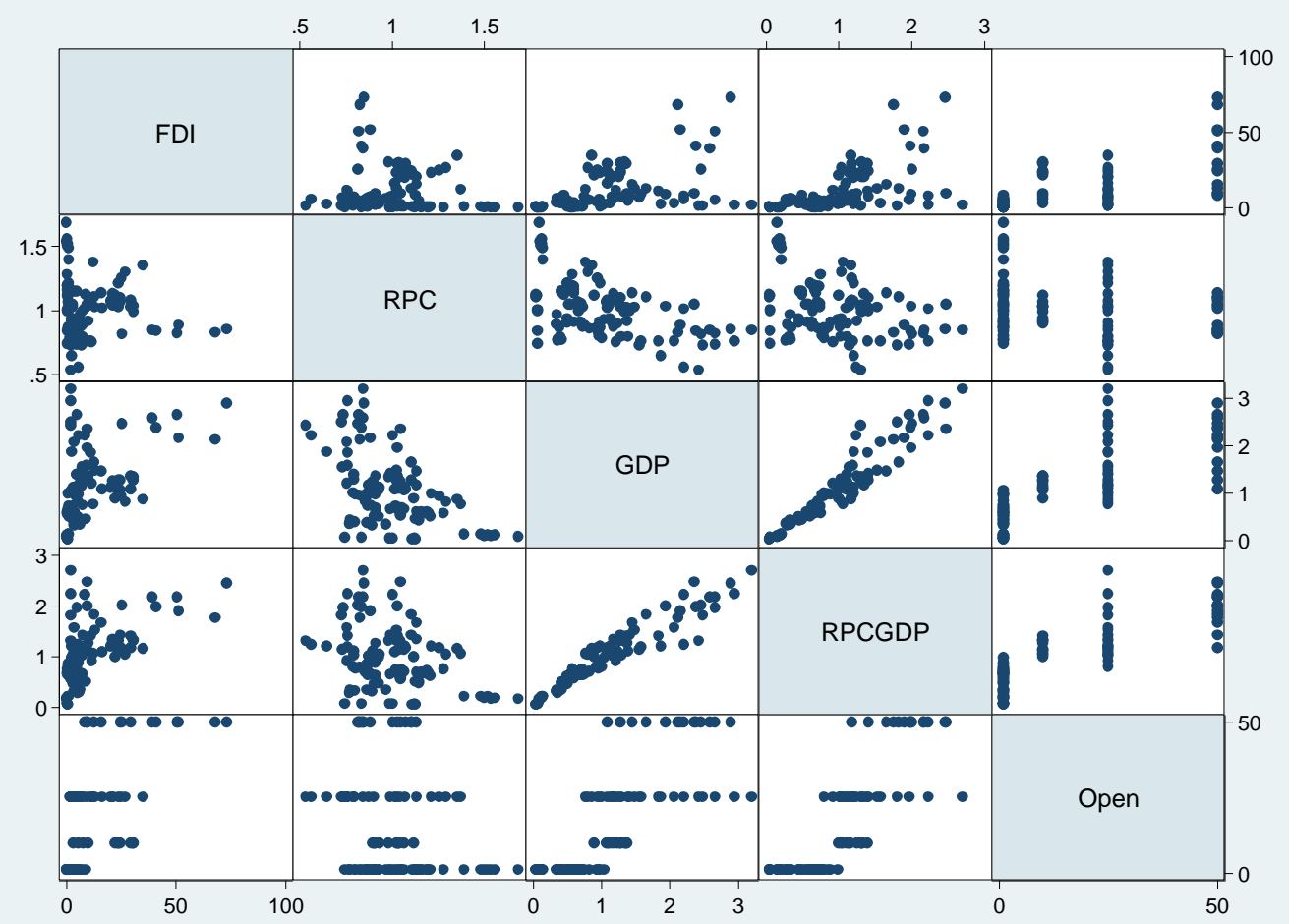

\section{APPENDIX R}


List of Indian Provinces and Variables: FDI, RPC*GDP, Democracy, and

\section{Open Economy}

\begin{tabular}{|c|c|c|c|c|c|c|c|}
\hline Source & SS & $d f$ & \multicolumn{2}{|c|}{ MS } & & \multirow{3}{*}{$\begin{array}{l}\text { Number of obs } \\
\text { F( 2, 102) } \\
\text { Prob > F } \\
\text { R-squared } \\
\text { Adj R-squared } \\
\text { Root MSE }\end{array}$} & \multirow{3}{*}{$\begin{array}{rr}= & 105 \\
= & 38.49 \\
= & 0.0000 \\
= & 0.4301 \\
= & 0.4189 \\
= & 10.823\end{array}$} \\
\hline $\begin{array}{r}\text { Mode1 } \\
\text { Residua1 }\end{array}$ & $\begin{array}{l}9017.80089 \\
11948.8555\end{array}$ & $\begin{array}{r}2 \\
102\end{array}$ & \multicolumn{2}{|c|}{$\begin{array}{l}4508.90044 \\
117.145642\end{array}$} & & & \\
\hline Tota1 & 20966.6564 & 104 & \multicolumn{2}{|c|}{201.602465} & & & \\
\hline FDI & coef. & Std. & Err. & $\mathrm{t}$ & $P>|t|$ & [95\% Conf. & Interva1] \\
\hline $\begin{array}{r}\text { RPCGDP } \\
\text { Open } \\
\text { _cons }\end{array}$ & $\begin{array}{r}2.509929 \\
\dot{4655915} \\
1.078991\end{array}$ & $\begin{array}{l}3.10 \\
.113 \\
2.13\end{array}$ & $\begin{array}{l}4728 \\
2671 \\
5462\end{array}$ & $\begin{array}{l}0.81 \\
4.11 \\
0.51\end{array}$ & $\begin{array}{l}0.421 \\
0.000 \\
0.614\end{array}$ & $\begin{array}{r}-3.648285 \\
.2409268 \\
-3.156688\end{array}$ & $\begin{array}{l}8.668142 \\
.6902562 \\
5.314669\end{array}$ \\
\hline
\end{tabular}

\section{APPENDIX S}


List of Indian Provinces and Variables: FDI, RPC*GDP, Democracy, and Open Economy with Beta Coefficients

\begin{tabular}{|c|c|c|c|c|c|c|c|}
\hline Source & SS & $d f$ & \multicolumn{2}{|c|}{ MS } & & \multirow{3}{*}{$\begin{array}{l}\text { Number of obs } \\
\text { F( } 2,102) \\
\text { Prob }>F \\
\text { R-squared } \\
\text { Adj R-squared } \\
\text { Root MSE }\end{array}$} & \multirow{3}{*}{$\begin{array}{r}105 \\
38.49 \\
0.0000 \\
0.4301 \\
0.4189 \\
10.823\end{array}$} \\
\hline $\begin{array}{r}\text { Mode1 } \\
\text { Residua1 }\end{array}$ & $\begin{array}{l}9017.80089 \\
11948.8555\end{array}$ & $\begin{array}{r}2 \\
102\end{array}$ & $\begin{array}{l}450 \\
117\end{array}$ & $\begin{array}{l}0044 \\
5642\end{array}$ & & & \\
\hline Tota1 & 20966.6564 & 104 & 201 & 2465 & & & \\
\hline FDI & coef. & std. & Err. & $\mathrm{t}$ & $P>|t|$ & & Beta \\
\hline $\begin{array}{r}\text { RPCGDP } \\
\text { Open } \\
\text { _cons }\end{array}$ & $\begin{array}{r}2.509929 \\
.4655915 \\
1.078991\end{array}$ & $\begin{array}{l}3.104 \\
.1132 \\
2.135\end{array}$ & $\begin{array}{l}728 \\
671 \\
462\end{array}$ & $\begin{array}{l}0.81 \\
4.11 \\
0.51\end{array}$ & $\begin{array}{l}0.421 \\
0.000 \\
0.614\end{array}$ & & $\begin{array}{l}.1102868 \\
.5607731\end{array}$ \\
\hline
\end{tabular}

\section{APPENDIX T}


List of Indian Provinces and Variables: FDI, RPC*GDP, Democracy, and Open Economy with BP Test and Robust Standard Errors

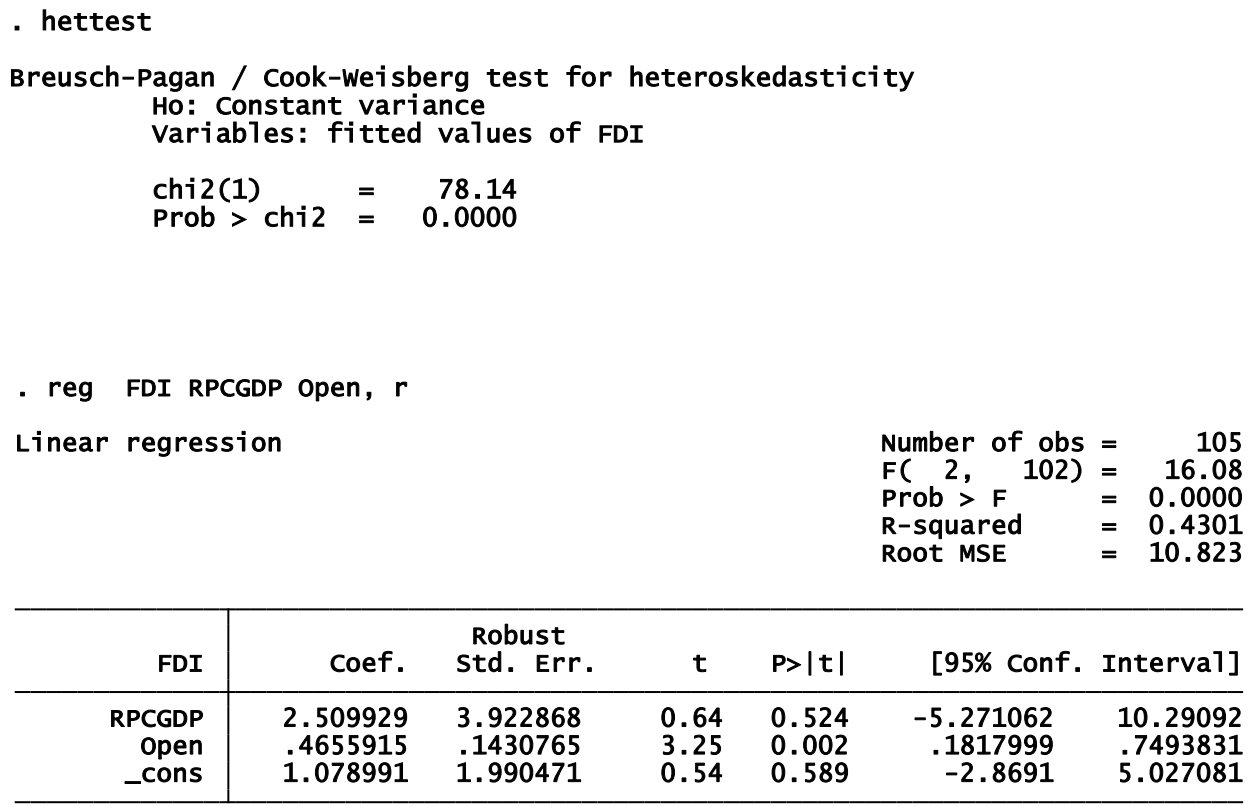

\begin{tabular}{r|rlrrrr}
\hline \multirow{2}{*}{ FDI } & Coef. & Sobust \\
& Std. Err. & $\mathrm{t}$ & $\mathrm{P}>|\mathrm{t}|$ & \multicolumn{2}{c}{ [95\% Conf. Interva1] } \\
\hline RPCGDP & 2.509929 & 3.922868 & 0.64 & 0.524 & -5.271062 & 10.29092 \\
Open & .4655915 & 1430765 & 3.25 & 0.002 & .1817999 & .7493831 \\
_Cons & 1.078991 & 1.990471 & 0.54 & 0.589 & -2.8691 & 5.027081 \\
\hline
\end{tabular}




\section{APPENDIX U}

List of Indian Provinces and Variables: FDI, RPC*GDP, Democracy, and Open Economy with VIF Test and Independence Test

\begin{tabular}{|c|c|c|}
\hline Variable & VIF & $1 / \mathrm{VIF}$ \\
\hline $\begin{array}{r}\text { Open } \\
\text { RPCGDP }\end{array}$ & $\begin{array}{l}3.33 \\
3.33\end{array}$ & $\begin{array}{l}0.300210 \\
0.300210\end{array}$ \\
\hline Mean VIF & 3.33 & \\
\hline
\end{tabular}

. Tinktest

\begin{tabular}{|c|c|c|c|c|c|c|c|}
\hline Source & ss & $d f$ & \multicolumn{2}{|c|}{ MS } & & \multirow{3}{*}{$\begin{array}{l}\text { Number of obs } \\
\text { F( } 2,102) \\
\text { Prob > F } \\
\text { R-squared } \\
\text { Adj R-squared } \\
\text { Root MSE }\end{array}$} & \multirow{3}{*}{$\begin{array}{rr}= & 105 \\
= & 39.94 \\
= & 0.0000 \\
= & 0.4392 \\
= & 0.4282 \\
= & 10.737\end{array}$} \\
\hline $\begin{array}{r}\text { Mode1 } \\
\text { Residua1 }\end{array}$ & $\begin{array}{r}9208.81639 \\
11757.84\end{array}$ & $\begin{array}{r}2 \\
102\end{array}$ & $\begin{array}{r}46 \\
115\end{array}$ & $\begin{array}{l}082 \\
941\end{array}$ & & & \\
\hline Total & 20966.6564 & 104 & 201 & 2465 & & & \\
\hline FDI & Coef. & std. & Err. & $t$ & $P>|t|$ & [95\% Conf. & Interval] \\
\hline $\begin{array}{r}\text { _hat } \\
\text { _hatsq } \\
\text { _cons }\end{array}$ & $\begin{array}{r}.4823085 \\
.0177532 \\
1.945937\end{array}$ & $\begin{array}{l}.4177 \\
.0137 \\
2.185\end{array}$ & $\begin{array}{l}518 \\
913 \\
846\end{array}$ & $\begin{array}{l}1.15 \\
1.29 \\
0.89\end{array}$ & $\begin{array}{l}0.251 \\
0.201 \\
0.375\end{array}$ & $\begin{array}{l}-.3463003 \\
-.0096018 \\
-2.389679\end{array}$ & $\begin{array}{l}1.310917 \\
.0451081 \\
6.281553\end{array}$ \\
\hline
\end{tabular}

\section{APPENDIX V}


List of Indonesian Provinces and Variables: FDI, RPC, GDP, RPC*GDP, Democracy,

$$
\text { and Open Economy }
$$

- reg FDI RPC GDP RPCGDP open

\begin{tabular}{r|crc} 
Source & SS & df & MS \\
\hline Mode1 & 488.399445 & 4 & 122.099861 \\
Residua1 & 254.600809 & 177 & 1.43842265 \\
\hline Total & 743.000255 & 181 & 4.10497378
\end{tabular}

Number of obs $=\quad 182$

$F(4,177)=84.88$

Prob $>\mathrm{F}=0.0000$

R-squared $=0.6573$

Adj R-squared $=0.6496$

Root MSE $=1.1993$

\begin{tabular}{r|rrrrrr}
\hline FDI & Coef. & std. Err. & $\mathrm{t}$ & $\mathrm{P}>|\mathrm{t}|$ & \multicolumn{2}{c}{ [95\% Conf. Interva1] } \\
\hline RPC & -.3358668 & .1824391 & -1.84 & 0.067 & -.6959026 & .024169 \\
GDP & -3.02872 & .6792864 & -4.46 & 0.000 & -4.369262 & -1.688177 \\
RPCGDP & 2.70909 & .3199174 & 8.47 & 0.000 & 2.077746 & 3.340433 \\
Open & .1540622 & .0179519 & 8.58 & 0.000 & .1186349 & .1894895 \\
_Cons & .6347423 & .2245881 & 2.83 & 0.005 & .1915273 & 1.077957 \\
\hline
\end{tabular}

\section{APPENDIX W}


Correlation Matrix for Indonesian Provincial Governments

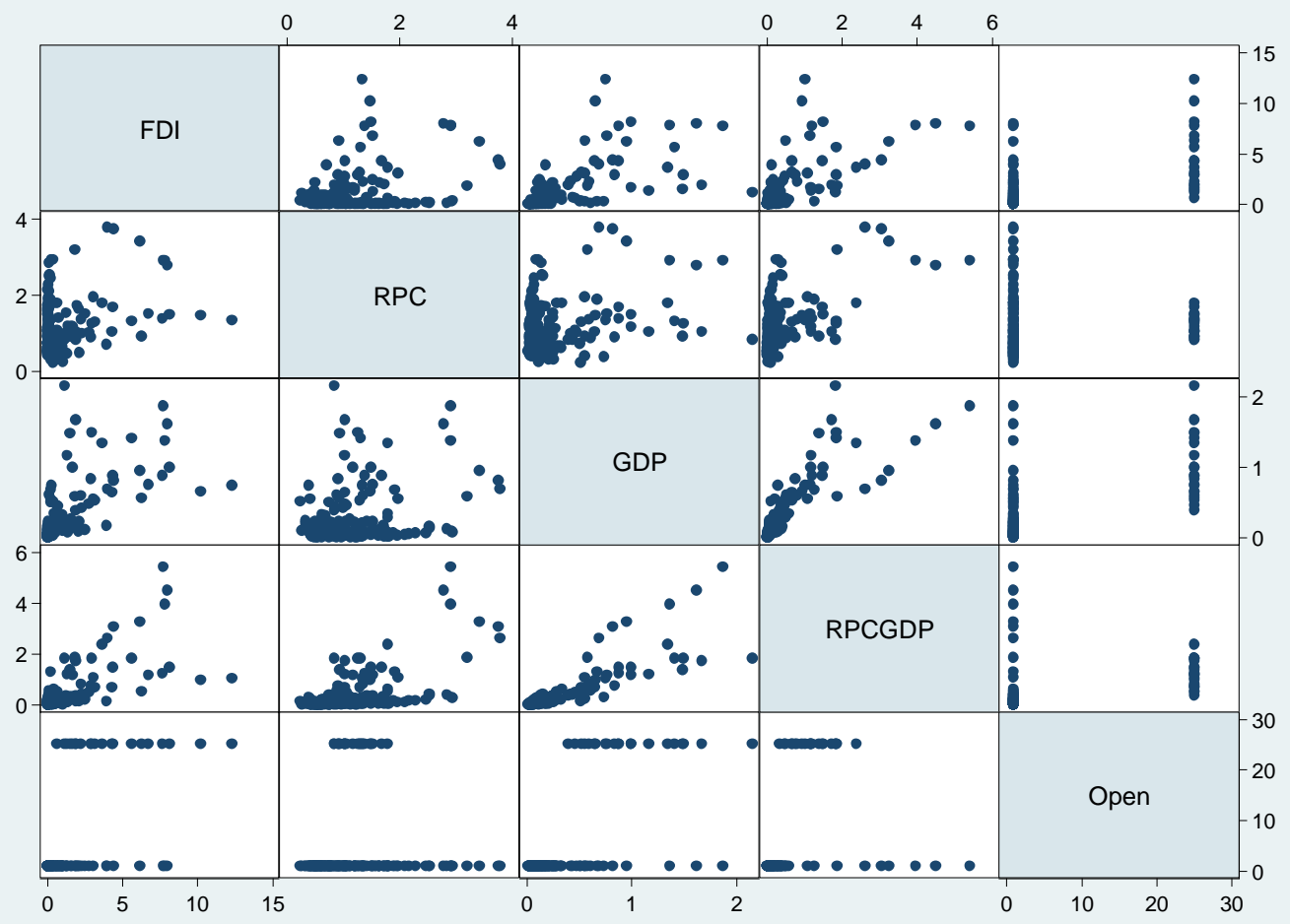

\section{APPENDIX $X$}


List of Indonesian Provinces and Variables: FDI, RPC*GDP, Democracy, and

\section{Open Economy}

\begin{tabular}{|c|c|c|c|c|c|c|c|}
\hline Source & ss & $d f$ & \multicolumn{2}{|c|}{ MS } & & \multirow{3}{*}{$\begin{array}{l}\text { Number of obs } \\
\text { F( } 2,179) \\
\text { Prob }>F \\
\text { R-squared } \\
\text { Adj R-squared } \\
\text { Root MSE }\end{array}$} & \multirow{3}{*}{$\begin{array}{rr}= & 182 \\
= & 145.29 \\
= & 0.0000 \\
= & 0.6188 \\
= & 0.6146 \\
= & 1.2579\end{array}$} \\
\hline $\begin{array}{r}\text { Mode1 } \\
\text { Residual }\end{array}$ & $\begin{array}{l}459.780423 \\
283.219832\end{array}$ & $\begin{array}{r}2 \\
179\end{array}$ & $\begin{array}{r}229 \\
1 .\end{array}$ & $\begin{array}{l}0212 \\
2337\end{array}$ & & & \\
\hline Total & 743.000255 & 181 & 4.1 & 97378 & & & \\
\hline FDI & Coef. & std. & Err. & $\mathrm{t}$ & $P>|t|$ & [95\% Conf. & Interva1] \\
\hline $\begin{array}{r}\text { RPCGDP } \\
\text { Open } \\
\text { _cons }\end{array}$ & $\begin{array}{l}1.475341 \\
.0976624 \\
.1227931\end{array}$ & $\begin{array}{l}.1285 \\
.0130 \\
.1085\end{array}$ & $\begin{array}{l}396 \\
894 \\
287\end{array}$ & $\begin{array}{r}11.48 \\
7.46 \\
1.13\end{array}$ & $\begin{array}{l}0.000 \\
0.000 \\
0.259\end{array}$ & $\begin{array}{r}1.221693 \\
.071833 \\
-.0913672\end{array}$ & $\begin{array}{r}1.728989 \\
.1234919 \\
.3369534\end{array}$ \\
\hline
\end{tabular}

\section{APPENDIX Y}


List of Indonesian Provinces and Variables: FDI, RPC*GDP, Democracy, and Open

Economy with Beta Coefficients

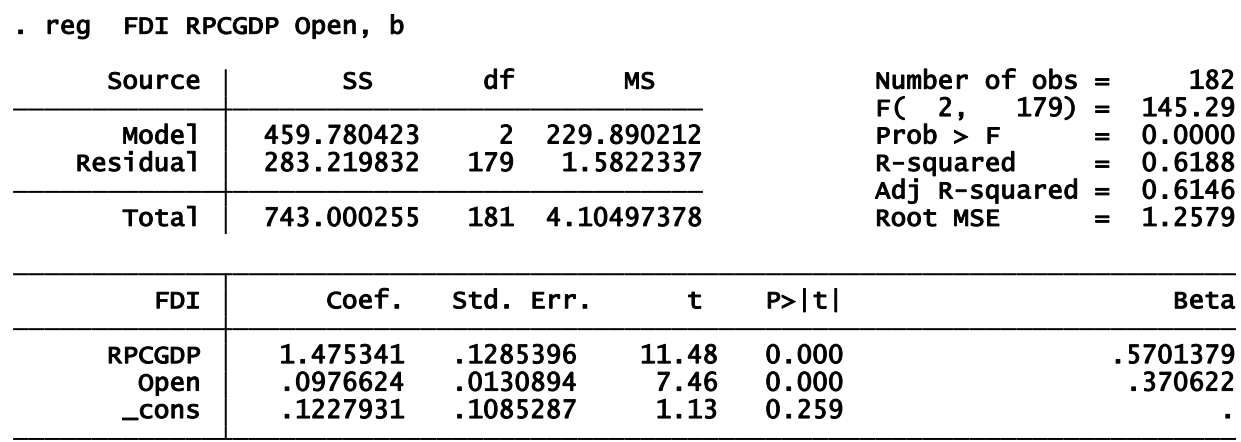

\section{APPENDIX Z}


List of Indonesian Provinces and Variables: FDI, RPC*GDP, Democracy, and Open

Economy with BP Test and Robust Standard Errors

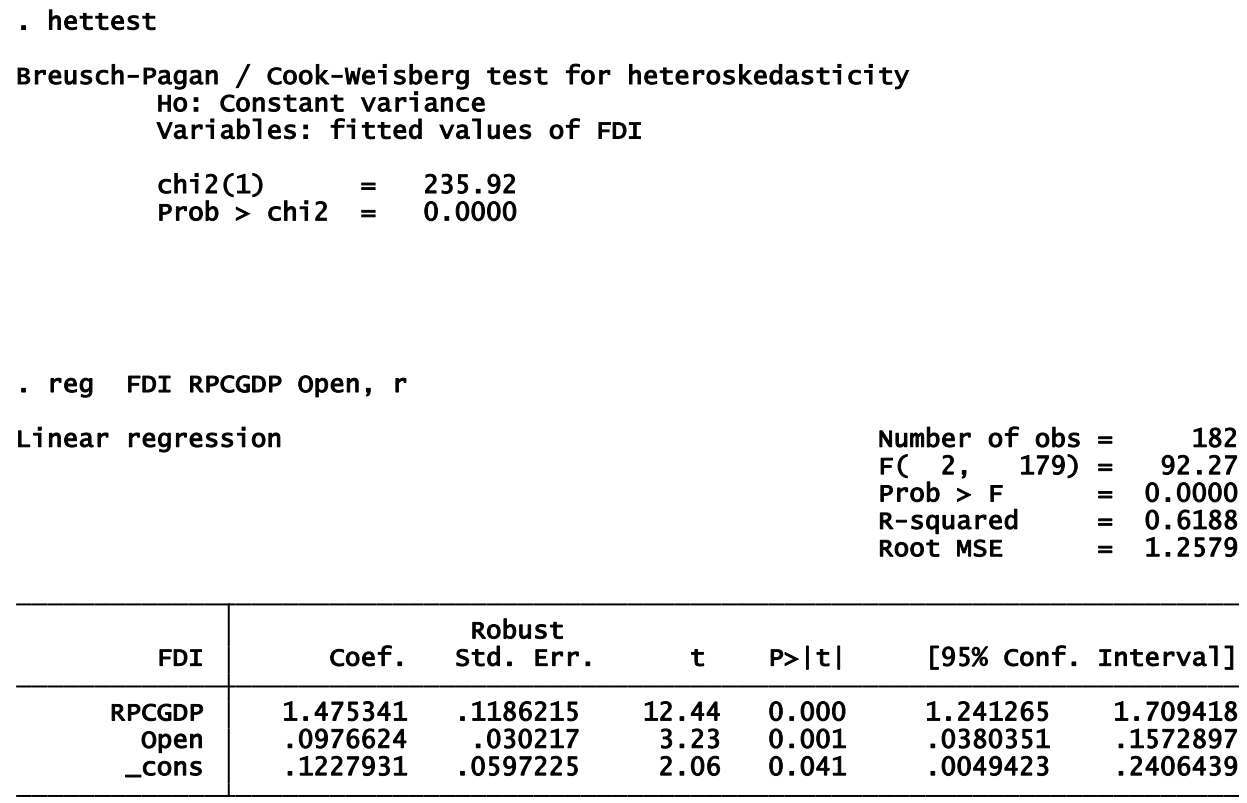

\section{APPENDIX AA}


List of Indonesian Provinces and Variables: FDI, RPC*GDP, Democracy, and Open

Economy with VIF Test and Independence Test

- vif

\begin{tabular}{r|rr} 
Variable & VIF & $1 /$ VIF \\
\hline Open & 1.16 & 0.863044 \\
RPCGDP & 1.16 & 0.863044 \\
\hline Mean VIF & 1.16 &
\end{tabular}

. linktest

\begin{tabular}{|c|c|c|c|c|c|c|c|}
\hline Source & ss & df & \multicolumn{2}{|c|}{ MS } & & \multirow{3}{*}{$\begin{array}{l}\text { Number of obs } \\
\text { FC 2, 179) } \\
\text { Prob > F } \\
\text { R-squared } \\
\text { Adj R-squared } \\
\text { Root MSE }\end{array}$} & \multirow{3}{*}{$\begin{array}{rr}= & 182 \\
= & 146.78 \\
= & 0.0000 \\
= & 0.6212 \\
= & 0.6170 \\
= & 1.2539\end{array}$} \\
\hline $\begin{array}{r}\text { Mode1 } \\
\text { Residual }\end{array}$ & $\begin{array}{l}461.556737 \\
281.443518\end{array}$ & $\begin{array}{r}2 \\
179\end{array}$ & $\begin{array}{l}230 \\
1.5\end{array}$ & $\begin{array}{l}8368 \\
1016\end{array}$ & & & \\
\hline Total & 743.000255 & 181 & 4.1 & 97378 & & & \\
\hline FDI & Coef. & std. & Err. & $t$ & $P>|t|$ & [95\% Conf. & Interva1] \\
\hline $\begin{array}{r}\text { _hat } \\
\text { _hatsq } \\
\text { _cons }\end{array}$ & $\begin{array}{r}1.218578 \\
-.0384942 \\
-.0912672\end{array}$ & $\begin{array}{l}.2137 \\
.0362 \\
.1409\end{array}$ & $\begin{array}{l}971 \\
164 \\
198\end{array}$ & $\begin{array}{r}5.70 \\
-1.06 \\
-0.65\end{array}$ & $\begin{array}{l}0.000 \\
0.289 \\
0.518\end{array}$ & $\begin{array}{r}.7966911 \\
-.1099601 \\
-.369345\end{array}$ & $\begin{array}{l}1.640465 \\
.0329718 \\
.1868106\end{array}$ \\
\hline
\end{tabular}

